\title{
FLORISTIC RELATIONSHIPS OF NEW CALEDONIAN RAINFOREST PHANEROGAMS
}

\author{
Ph. Morat 1 , J.-M. Veillon ${ }^{1}$ \& H. S. MacKee 2
}

(Accepted for publication 16.9.1983)

\begin{abstract}
Morat, Ph. ${ }^{l}$, Veillon, J.-M.I \& MacKee, H. S. ${ }^{2}$ ('Centre ORSTOM, B.P. A5 Cedex, Nouméa, New Caledonia: ${ }^{2}$ B.P. 3369, Nouméa, New Caledonia) 1986. Floristic relationships of New Caledonian rainforest phanerogams. Telopea 2(6): 631-679-A detailed analysis of the New Caledonian rainforest flora is given; 1499 species in 365 genera and 108 families are listed. Distribution of the species within New Caledonia is given in terms of specificity to rainforest (forest/non-forest and forest occurrence) and to substrate (only ultrabasic/absent from ultrabasic/present on ultrabasic and other substrates). Distribution of genera is presented according to occurrences in 12 phytogeographic units from endemic to pantropical. Sources of information are given. Comparisons with the whole New Caledonian phanerogamic flora are made; $46 \%$ of genera and species and $66 \%$ of families occur in the rainforest. For the flora the level of specific endemism is c. $75 \%$. Floristic affinities are assessed by: comparison of numbers of genera shared with other regions (pantropical genera included/excluded); and numbers of genera shared exclusively by New Caledonia and $2,3,4,5$ or 6 other regions. In these comparisons Australia, New Guinea, Malesia, Fiji, the New Hebrides, the Solomon Islands and then New Zealand have the most genera in common with New Caledonia. A floristic affinity co-efficient for each territory was calculated from the proportion of the number of common genera to the number of territories in which they occur, for groups of two to six territories. From these data, the calculated floristic affinities are Australia - 27\%, New Guinea - 20\%, Malesia - 12\%, Fiji - 10\%, New Hebrides $-7.5 \%$, Solomons $-7 \%$ and New Zealand - 3\%. Origins of the New Caledonian flora are discussed in relation to the geological history; continental isolation since the Permian, proximity of north-eastern Australia and New Guinea until the lower Cretaceous, and early Tertiary formation of widespread peridotites are major factors in the development of this flora. Comparisons of edaphic preferences show that c. $30 \%$ of species occur only on ultrabasic substrates, c. $40 \%$ are restricted to other substrates, and c. $30 \%$ occur on both sets of substrates. Of the exclusively forest species, c. 500 are restricted to substrates other than ultrabasics, and c. 300 to ultrabasics. Groupings of families according to substrates are also given. The authors question the positive influence of the ultrabasic substrates on the floristic richness and on the conservation of archaic ancestral components of the flora.
\end{abstract}

\section{INTRODUCTION}

New Caledonia has long attracted phytogeographical analysis (Balansa 1873, Brongniart 1874, Fournier 1874, Brousmiche 1884, Bernard 1895, Guillaumin 1921, 1924, 1928, 1934, 1954, 1964a, Virot 1956, BaumannBodenheim 1956, Thorne 1965, 1969, van Balgooy 1960, 1971). Early botanists working on the flora were quick to recognize its originality. When it became better known, together with other Pacific floras, the high proportion of endemics was emphasized both at specific ( $76 \%$ for Guillaumin 1921 ; $90 \%$ for BaumannBodenheim 1956, Guillaumin 1964a) and at generic level (1\% for Brongniart $1874,13.5 \%$ for Thorne $1969,16 \%$ for van Balgooy 1960). Floristic links were demonstrated, mainly with Australia and New Guinea (Thorne 1965, van Balgooy 1960, 1971). The presence of numerous archaic forms (gymnosperms and primitive angiosperms) led authors concerned with Pacific phytogeography to recognize the individuality of the island, defined as a 'Région canaque' (Guillaumin 1928, 1934), 'New Caledonian Region' (Good 1964, van Balgooy 1960, 1971), 'Sub-region' (Thorne 1963), 'Sub-kingdom' (Takhtajan 1969). 
The time has come to reconsider the biogeographic relationships of the Territory. The most recent publications (Thorne 1965, van Balgooy 1971) are in fact based on distinctly earlier data (Guillaumin 1948, Baumann-Bodenheim 1956). Later botanical advances in New Caledonia and in the Pacific generally justify a new approach, which is the first aim of the present article. Attention is here focussed on the rainforest, a choice that greatly reduces uncertainties in distinguishing native species from those of relatively recent introduction. The rainforest has, for our purposes, the clear advantage that for obvious climatic and palaeoclimatic reasons, relict forms are better conserved in it than elsewhere. Unless seriously disturbed it resists invasion by outside elements, real floristic affinities being thus more evident. Such forests exist in New Caledonia on a wide range of substrates - limestone, basalt, schist, greywacke, clays and also the ultrabasic rocks (peridotites and serpentinites), which produce exceptional edaphic conditions affecting the whole mineral nutrition of plants (excess of $\mathrm{Mg}$ and the heavy metals $\mathrm{Ni}, \mathrm{Cr}, \mathrm{Mn}$; deficiency of $\mathrm{P}$ and $\mathrm{K}$ ). These special conditions are often invoked (Virot 1956, Thorne 1965, Jaffré 1980) to explain the abundance and persistence of primitive relict forms. The second aim of this study is to check this hypothesis by a quantitative analysis of the species according to their habitats.

\section{METHODS}

All available data have been reconsidered in listing as completely as possible all species recorded for the Territory. Doubtful taxa have been eliminated, as well as introduced plants, as we deal only with the native phanerogamic flora.

\section{The rainforest}

We deal with the rainforest as defined and mapped in the "Atlas de la Nouvelle-Calédonie' (Morat et al. 1981), thus covering the following formations in their essentially intact state: dense evergreen forest of low and medium altitudes; dense mountain forest; the edaphic variant represented by evergreen forest on limestone. All other forest or similar formations are excluded sclerophyll forest, swamp forest, mangrove, tall shrubland, gallery forest, etc. The rainforest covers 300000 ha on the main island plus 100000 ha in the Loyalties and the Isle of Pines, equivalent to $22 \%$ of the total surface of the Territory of New Caledonia (Fig.1).

\section{Species of the rainforest}

All plants are included whose occurrence in undisturbed rainforest is constant and unequivocal, regardless of their abundance, their bulk, their association with any particular stratum or biological type or their possible presence in other formations. The stipulation of undisturbed forest excludes all 'secondary' species which, colonizing forest edges or openings where a large tree has fallen, penetrate accidentally and temporarily into the forest, unless they exist, even rarely, within the intact formation. Rubus moluccanus, for example, a species very probably native, but known in forest only in disturbed and open situations, is omitted. A few heliophilic species are, however, included, e.g. Duboisia myoporoides, a shrub or small tree appearing abundantly whenever an opening (track or clearing) is made, but definitely known, though rare, in normal rainforest. Other species characteristic of adjacent stations, such as coastal scrub or gallery forest, occur exceptionally in rainforest. Their presence, due to an accidental introduction or to a transitory situation (edge of a rapidly advancing 


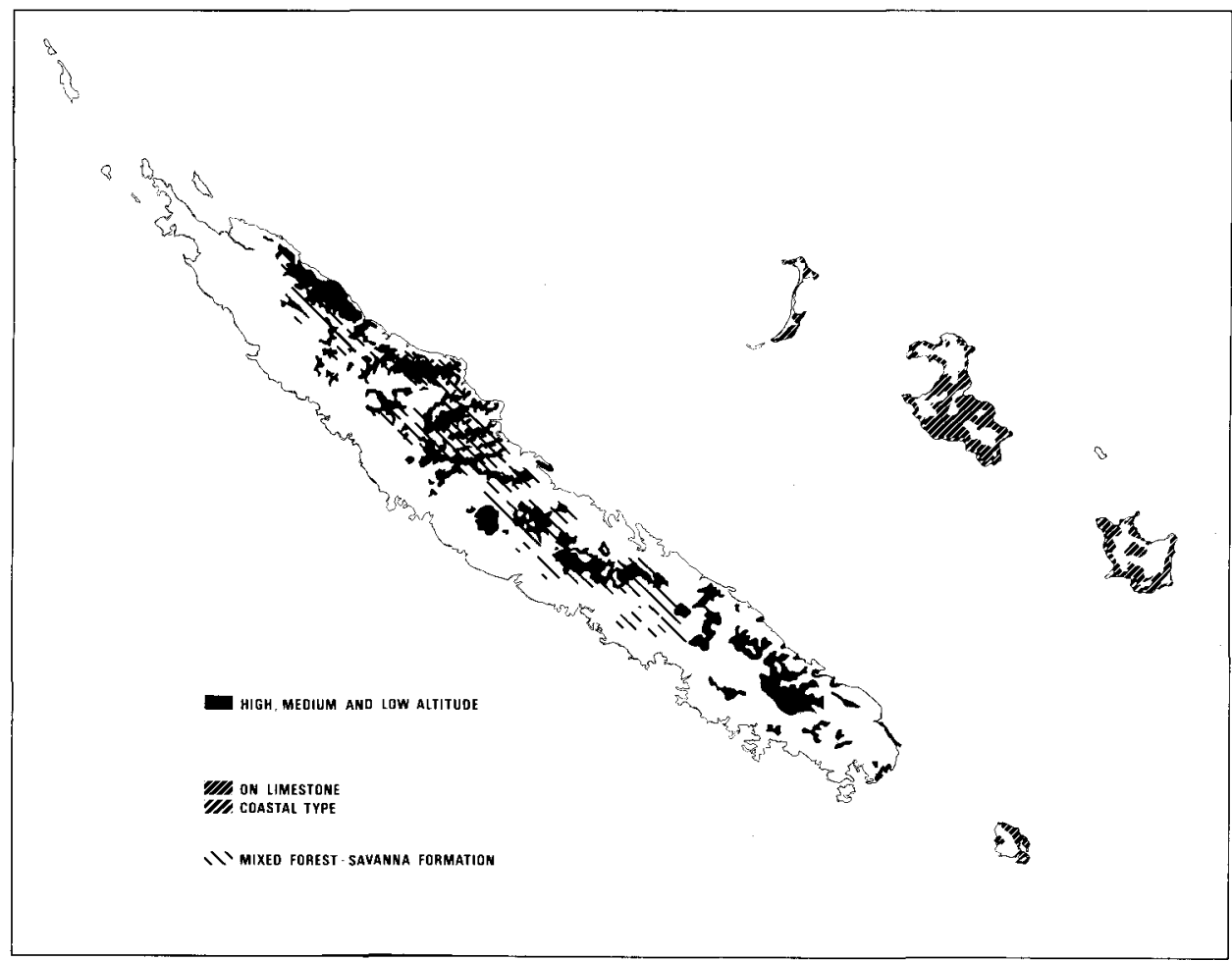

Figure 1. Rainforest in New Caledonia.

rainforest), is only sporadic. Such species are excluded, e.g. Eriaxis rigida (Orchidaceae), Gahnia neocaledonica (Cyperaceae), Joinvillea spp. (Flagellariaceae), Allophylus cobbe (Sapindaceae), Malaisia tortuosa (Moraceae), Gouania leratii (Rhamnaceae), Lindenia vitiensis (Rubiaceae), Heliconia sp. (Musaceae), etc.

Precise delimitation of the rainforest is often difficult, and where it passes progressively into tall shrubland, gallery forest or secondary forest, becomes essentially subjective. Each doubtful taxon has therefore been considered individually and those retained which best meet the chosen criteria in the light of existing literature, notes on herbarium sheets and, above all, our own observations and reflections.

Rainforest species are listed in Appendix 1. Forest species (F) are those found only in rainforest. Species found also in other formations are referred to as mixed (M). The following groups are defined to determine the effect of substrates on floristic diversity and on the level of endemism:

- species growing only on ultrabasic substrates

- species absent from ultrabasic substrates

- species growing on both types of substrate

\begin{tabular}{|c|ccc|}
\hline & U & A & I \\
\hline F & FU & FA & FI \\
M & MU & MA & MI \\
\hline
\end{tabular}

Subspecies are not considered. If a species has subspecies of different edaphic status ( $U$ or $A$ ), the species as a whole is classed as I. The following categories thus exist among strictly forest species and those present also in one or more other formations. 
The substrate has little if any influence on the distribution of epiphytes. Possible associations between epiphytes and their hosts are too little known to offer significant correlations with substrates. Parasitic Loranthaceae are, however, much more closely associated with their hosts, whose edaphic status they receive.

As with the data already considered, it is sometimes hard to assign a definite edaphic status to particular species. Some parts of the Territory still lack detailed geological maps, and even these cannot show all small-scale variations. Here also, published data and information on herbarium sheets, used critically and with caution, have been completed by our own observations. Doubtful species are left without edaphic status.

\section{Genera and families of the rainforest}

These are established using the lists of species occurring exclusively $(\mathrm{F})$ or partially (M) in this formation. It may be noted that certain genera (Acridocarpus, Erythroxylum, Grevillea, Isachne, etc.) are excluded as having no forest species in New Caledonia although represented elsewhere in rainforest.

The genus is adopted as the working unit in phytogeographical analyses, for the reasons already cited by van Balgooy (1971) (more homogenous comparisons, relative numerical stability at different dates, definition generally sounder than that of species). In some cases, however, subgenera or sections are considered more significant than the genus itself in establishing floristic relationships: e.g. subgenus Antholoma rather than Sloanea; section Scaevola less its two pantropical species instead of the genus Scaevola. Certain genera whose limits seem ill-defined are considered together, e.g. Caryophyllus and Jambosa with Syzygium.

Rainforest genera are listed in Appendix 2. This list does not agree completely with the list of species (Appendix 1) because of nomenclatural complications arising when authors publish new genera or new synonymy without making, at specific level, all the new combinations that seem to be required: e.g. Gymnostoma (Casuarinaceae) for some species of Casuarina (Johnson 1980); Eucarpha and Virotia (Proteaceae) for some species of Knightia and Macadamia (Johnson \& Briggs 1975); Cassine (Celastraceae) for Elaeodendron (Ding Hou 1962); Anthocarapa for Amoora (Pennington \& Styles 1975); Pisonia (Nyctaginaceae) for Calpidia (Stemmerik 1964); Lethedon (Thymeleaceae) for Microsemma (Kostermans 1963), etc. Elsewhere, generic changes are only proposed by the specialists concerned, e.g. transfer to Medicosma of Melicope p.p. (Rutaceae) (T. G. Hartley pers. comm.) or revival of Tristaniopsis, a genus long reduced to synonymy under Tristania (Myrtaceae) (J. W. Dawson pers. comm.). In neither case is it for us to make the combinations instead of the authors proposing new generic limits. Such taxa appear, therefore, under their current binomials in the specific list and under the new generic name in the lists of geographical distribution. The quantitative results are not affected, being derived separately from each list.

\section{SOURCES OF INFORMATION}

These are too numerous to be cited completely; the most important have already been mentioned or appear in the references. For the nomenclatural status of taxa and for their distribution within New Caledonia in relation to edaphic factors, the sources are of three types: the existing literature; the herbarium of Centre ORSTOM (Nouméa); and naturally, personal observations. 
The literature is considerable and scattered through many journals, floras, lists and compendia. We have first considered the most recent floras and revisions, in particular the Flore de la Nouvelle-Calédonie et Dépendances in which 16 families (four gymnosperm families, Sapotaceae, Proteaceae, Lauraceae, Epacridaceae, Orchidaceae, Solanaceae, Acanthaceae, Bignoniaceae, Symplocaceae, Flacourtiaceae, Icacinaceae and Corynocarpaceae) concerned in this work have appeared. There may be added seven families (Elaeocarpaceae, Apocynaceae, Trimeniaceae, Monimiaceae, Atherospermataceae, Chloranthaceae and Amborellaceae) in course of publication, the manuscripts or relevant information having been communicated to us. Numerous families represented in the rainforest have also been studied recently in whole or in part. These are Anacardiaceae (Euroschinus), Araliaceae (Arthrophyllum), Balanopaceae, Celastraceae (Salaciopsis), Chrysobalanaceae, Cunoniaceae (Acsmithia), Cyperaceae (Baumea, Costularia, Gahnia), Euphorbiaceae (Austrobuxus, Baloghia, Bocquillonia), Fagaceae, Loganiaceae (Geniostoma), Meliaceae, Mimosaceae (Albizia, Pithecellobium, Serianthes), Moraceae, Myrtaceae (Leptospermoideae), Oncothecaceae, Palmae, Pandanaceae, Pittosporaceae, Rutaceae, Rubiaceae (Tarenna) and Winteraceae. Recent reliable revisions cover about $65 \%$ of the flora here studied. For the rest we have used the results, modified where necessary, of the Mission Franco-Suisse (Guillaumin 1957, 1962, 1964b, 1967, 1974). Earlier sources include numerous and varied publications by Schlechter, E. G. Baker, S. Moore, Rendle, Aubréville, Virot, Thorne and others (see references). Obvious errors such as the superfluous generic name Merismostigma $\mathrm{S}$. Moore, based on a species of Coelospermum B1., have been corrected.

The local flora is well represented in the herbarium (40000 specimens) of Centre ORSTOM (Nouméa), another significant source of information, used critically, on the edaphic status of species. It is also distinctly useful in questions of nomenclature, thanks to many determinations by specialists of families not yet treated in Flore de la Nouvelle-Calédonie.

Geographical distributions outside New Caledonia are taken exclusively from the literature. The starting point was the remarkable work of van Balgooy (1971), modified and brought up to date in view of new data in later publications already cited and in recent volumes of Flora Malesiana, in Pacific Plant Areas and in the first volume of Flora Vitiensis Nova. Finally, the eighth edition of A Dictionary of Flowering Plants and Ferns (Willis 1973) and the Dictionary of Australian Plant Genera (Burbidge 1963) served to settle a few outstanding questions.

\section{GEOGRAPHICAL DIVISIONS}

The phytogeographical units of van Balgooy (1971) are modified as we are concerned with New Caledonia rather than the whole Pacific.

Africa - includes the whole continent, plus Madagascar, the Mascarene Islands and the Seychelles; the islands are distinguished by a number* if a New Caledonian genus is, in this subdivision, limited to one or more of them.

Asia - includes the whole continent (except the Malay peninsula), plus Japan.

Malesia - covers the geographical area of Flora Malesiana (including the Philippines), except New Guinea, the Bismarck Archipelago and the Aru islands.

\footnotetext{
*See Appendix 2
} 
New Guinea - plus the Bismarck Archipelago and the Aru islands.

Australia - (including Tasmania).

\section{Pacific}

Solomon Islands, including Bougainville, which geographically belongs here.

New Hebrides, in the geographical sense, i.e. including the present Vanuatu and the Santa Cruz group.

\section{Lord Howe Island.}

\section{Norfolk Island.}

New Zealand and associated islands (Chathams, Kermadecs, Stewart).

\section{Fiji.}

North Pacific, an arbitrary unit grouping the following islands - Bonins, Carolines, Mariannes, Marshalls, Tuvalu, Phoenix, Tokelau, Hawaii.

Polynesia, includes French Polynesia plus the Cook Islands.

Samoa and Tonga, plus Niue, Wallis and Futuna.

America - the whole continent. North and South America are considered together as being little involved, apart from pantropical genera.

The Phoenix, Tokelau and Tuvalu Islands are associated with the North Pacific, on account of their geographical position and because all the relevant New Caledonian genera* that occur there are found also in the Carolines or the Mariannes.

\section{DISTRIBUTIONS}

The categories defined by van Balgooy (1971) and their content are also somewhat modified in the light of recent taxonomic studies and particularly because of the more limited scope of the present work.

Endemic genera (E), limited to New Caledonia, the Loyalties and the Isle of Pines.

New Caledonian (subendemic) genera (B), for which New Caledonia is a primary centre of diversification, having the great majority of the species (usually more than $3 / 4$ of the total; e.g. Meryta 19/25, Hedycarya 9/12, Coronanthera 9/11, Dizygotheca 17/17, one species being also in the New Hebrides). For such genera New Caledonia usually has a central position (Balanops, Baloghia, Meryta), but is sometimes eccentric (Coronanthera, Acianthus) or even at the limit of their area (Artia, Delarbrea). Other genera for which New Caledonia is a secondary centre of distribution with many species are not, however, considered 'New Caledonian', either because their areas are too wide and scattered for it to be their centre of dispersion (Araucaria 13/19, Soulamea $7 / 14$ (with one species in the Seychelles, one in Malesia and one in Polynesia), Euroschinus 4/6, Agathis 5/20, Campynema 1/2, Arthrophyllum 10/31, and also Dianella, Geniostoma, Phyllanthus, Pittosporum, etc.) or because their origin may well be elsewhere (Argophyllum, Austrobuxus, Geissois, etc.).

*Allophylus, Calophyllum, Calpidia, Epipremnum, Guettarda, Hemigraphis, Hernandia, Intsia, Macaranga, Morinda, Ochrosia, Pandanus, Planchonella. 
Pacific genera (L), found in one or more island groups in the Pacific but absent or rare in America, Asia, Australia, Malesia and New Guinea (e.g. Cyphosperma, Earina). This type of distribution is extended to the following genera: Ascarina with one species in Australia and Malesia and another (Jérémie 1980) in Madagascar; Dracophyllum (50 species, two of which occur in Tasmania and one in continental Australia); Storckiella (five species, one (B. P. Hyland pers. comm.) being Australian); Astelia (a few scattered species in Australia, New Guinea and South America); Tapeinosperma (39 species in New Caledonia, 11 in Fiji, two to three others in Australia, Malesia and New Guinea); Scaevola section Scaevola (less the two littoral species), extra-Australian but with two species in Malesia and New Guinea. More complex distributions are represented by Serianthes (four species in New Caledonia, five in other Pacific islands (Solomons, New Hebrides, Fiji, Polynesia), four others in New Guinea or Malesia), and Austromyrtus (nine Australian species and 28 others in the Pacific, including 12 in New Caledonia). Their inclusion in this group is justified by the weight of the Pacific species. Similarly, Campynema (one species endemic in New Caledonia, another endemic in Tasmania) is better placed here than among the Australian genera.

Subantarctic Pacific genera $(\mathrm{J})$ with disjunct distributions in New Caledonia and in the mountains of Australia, New Zealand and South America. Few occur in New Caledonia, owing to its geographical position and the absence of high mountains. The best examples are Araucaria and Nothofagus, also Decussocarpus, Dacrydium and Libocedrus (three species in New Caledonia, two in New Guinea, two in New Zealand and one in the Andes).

Subantarctic genera $(\mathrm{K})$ with distributions extending from the Pacific to the south of the Indian Ocean, such as Cordyline, Dianella, Podocarpus, the last being included here in spite of its vast distribution. Soulamea (one species in the Seychelles, one in Malesia and one in Polynesia, the other seven being New Caledonian) is placed in this group as is Cunonia whose extraordinary distribution includes $20 \mathrm{New}$ Caledonian endemics and a single other species, $C$. capensis, in South Africa. They probably belong to an ancient Gondwanian element.

Australian genera $(\mathrm{H})$ include those occurring mainly in Australia (e.g. Hibbertia, Styphelia) and even Duboisia and Niemeyera, each with two species in Australia and one in New Caledonia.

Australian-Papuan genera (I) are centred in Australia and New Guinea, such as Agathis, Corynocarpus, Euroschinus, Flindersia and Sphenostemon. Cupaniopsis is placed here; 26 of its 60 described species are New Caledonian but there are also many in New Guinea and some in Australia.

Malesian-Papuan genera $(G)$ have their centre of diversification in Malesia or New Guinea (with the Solomons and Fiji), or covering both these areas, and are poorly represented in Asia, Australia and Polynesia. Typical examples are Bureavella and Neuburgia.

Indo-Malesian genera (F), mainly Asian and Malesian, are little represented in Australia and the Pacific, their distributions often ending in New Caledonia or Fiji. This group, which oddly contains 12 orchid genera, is exemplified by Dacrycarpus, Procris, Acanthephippium, Appendicula and Coelogyne.

Indo-Australian genera (D) occur in continental Asia, Malesia, Australia and the Pacific, but are absent or almost so in Africa, such as Agapetes (sensu Sleumer 1966), Desmos, Neisosperma and Pachygone. 
Palaeotropical genera $(\mathrm{G})$ are absent only from America.

Pantropical genera (A).

\section{RESULTS}

The New Caledonian rainforest, as defined above, has 1499 described species of phanerogams, distributed in 365 genera and 108 families (Appendix 1). A comparison with the whole native phanerogamic flora is given in Table 1, showing that the rainforest has $46 \%$ of the genera and species and $66.7 \%$ of the families represented in the whole flora. It is, with almost half the species, the richest formation in the Territory.

The level of specific endemism for the whole native phanerogamic flora is about $76 \%$, well below the earlier estimates of Baumann-Bodenheim (1956) and Guillaumin (1964a), whose excessive figure of $90 \%$ has often been repeated. Endemism, as might be expected, is at all systematic ranks highest in the rainforest where all five endemic families occur.

TABLE 1. COMPARISON OF THE RAINFOREST FLORA WITH THE WHOLE NATIVE FLORA

\begin{tabular}{l|ccc|ccc|cc}
\cline { 2 - 9 } & \multicolumn{3}{c|}{ Species } & \multicolumn{3}{c|}{ Genera } & \multicolumn{2}{c}{ Families } \\
\cline { 2 - 9 } & Total & Endemic & $\begin{array}{c}\text { Endemic } \\
\%\end{array}$ & Total & Endemic & $\begin{array}{c}\text { Endemic } \\
\%\end{array}$ & Total & Endemic \\
\hline $\begin{array}{l}\text { Native } \\
\text { flora } \\
\begin{array}{l}\text { Rainforest } \\
\text { flora }\end{array} \\
\begin{array}{l}\text { Rainforest } \\
\text { flora as a } \\
\text { percentage } \\
\text { of total } \\
\text { lora }\end{array}\end{array}$ & 3256 & 2476 & 76.0 & 787 & 108 & 13.7 & 182 & 5 \\
\hline
\end{tabular}

\section{Floristic affinities}

The distribution spectrum is shown in Table 2. Genera of wide distribution (A, C, D) represent $45.4 \%$ of the rainforest flora, and Malesian genera $9.6 \%$. The Australian element $(\mathrm{H})$ is small $(3 \% *)$, but reaches the more significant level of $10.4 \%$ when Australian-Papuan genera (I) are included. The complete absence of American genera may be noted. This element, though not abundant, does occur in New Caledonia (Lindenia, Rubiaceae), but is absent from the rainforest. Southern genera (Subantarctic Pacific and Subantarctic) are mainly gymnosperms - Araucaria, Dacrydium, Decussocarpus, Libocedrus, Podocarpus and Prumnopitys. This old Gondwanian relict element preserved in the rainforest indicates very ancient relationships between the territories where it still exists. Pacific genera (L) are few $(4.1 \%)$. The most striking feature of Table 2 is, however, the large number of endemic genera $(82$, more than $22 \%$ of the total). Adding the 15 New Caledonian subendemic genera gives 97 genera $(26.5 \%)$ confined to or centred in New Caledonia and belonging to the most primitive families - Amborellaceae, Monimiceae, Myricaceae, Oncothecaceae, Palmae, Paracryphiaceae, Proteaceae, Winteraceae, etc.

\footnotetext{
*This figure, as will be seen later, does not reflect the floristic links between the two territories.
} 
TABLE 2. DISTRIBUTION OF RAINFOREST GENERA

\begin{tabular}{|c|c|c|c|c|}
\hline \multirow{2}{*}{$\begin{array}{l}\text { Type } \\
\text { Pantropical } \\
\text { Palaeotropical } \\
\text { Indo-Australian }\end{array}$} & \multirow{2}{*}{$\begin{array}{c}\text { Code } \\
\text { A } \\
\text { C } \\
\text { D }\end{array}$} & \multirow{2}{*}{$\begin{array}{c}\text { Number of Genera } \\
69 \\
51 \\
46\end{array}$} & \multicolumn{2}{|c|}{ Percentage of Total } \\
\hline & & & $\left.\begin{array}{l}18.9 \\
13.9 \\
12.6\end{array}\right\}$ & 45.4 \\
\hline $\begin{array}{l}\text { Indo-Malesian } \\
\text { Malesian-Papuan }\end{array}$ & $\stackrel{F}{G}$ & $\begin{array}{l}17 \\
18\end{array}$ & $\left.\begin{array}{l}4.7 \\
4.9\end{array}\right\}$ & 9.6 \\
\hline Australian & $\mathrm{H}$ & 11 & $3.0\}$ & \\
\hline Australian-Papuan & I & 27 & $7.4\}$ & 10.4 \\
\hline $\begin{array}{l}\text { Subantarctic Pacific } \\
\text { Subantarctic }\end{array}$ & $\begin{array}{l}\mathbf{J} \\
\mathrm{K}\end{array}$ & $\begin{array}{l}6 \\
8\end{array}$ & $\left.\begin{array}{l}1.7 \\
2.2\end{array}\right\}$ & 3.9 \\
\hline $\begin{array}{l}\text { Subantarctic } \\
\text { Pacific }\end{array}$ & $\mathrm{L}$ & 15 & 4.1 & \\
\hline Endemic & $\mathrm{E}$ & 82 & 22.4 & \\
\hline $\begin{array}{l}\text { New Caledonian } \\
\text { (subendemic) }\end{array}$ & B & 15 & $4.1\}$ & 26.5 \\
\hline TOTAL & & 365 & 100 & \\
\hline
\end{tabular}

Some endemic genera (Basselinia, Myodocarpus, Zygogynum) have a wide range of species, suggesting that their evolution has continued during a long period of isolation. Most, however, are oligotypic, many even monotypic, and appear as relicts at the end of an evolutionary line.

Floristic affinities may be evaluated in several ways. The number of genera shared between New Caledonia and various other territories is considered first (Table 3). The number of genera in common is high for New Guinea (246), Malesia (235) and Australia (233), and somewhat less for Fiji (192), continental Asia (188) and the New Hebrides (175).

These high figures are inflated by the 69 pantropical genera that mask the true affinities and whose presence, due to efficient dispersal, in various areas does not necessarily reflect floristic relationships. The comparison may thus be improved by eliminating all the pantropical genera. Tables 3 and 4 show a general reduction in shared genera when pantropical genera are not considered. This reduction is not, however, uniform (Fig. 2), being:

- $18 \%$ for America, which drops from 12th to 15 th place

- $10-12 \%$ for Africa, Asia and the North Pacific

- 7-8\% for Malesia, New Guinea, Australia, the Solomons, the New Hebrides, Fiji and Tonga-Samoa, the first six of these, after some changes in relative position, now taking the lead

- $5 \%$ for Lord Howe, Norfolk and Polynesia

- $1 \%$ for New Zealand. (Fig. 3.)

The last figures are easily explained, as pantropical genera are few in these essentially extratropical areas. Table 4 thus shows enhanced floristic affinities primarily with New Guinea (60\%), Australia (57\%), Malesia (56\%), and then with Fiji (45\%), the Solomons (42\%) and the New Hebrides (40\%). New Zealand $(14.5 \%)$ is well behind.

One could eliminate similarly other widespread elements such as, for example, the palaeotropical genera, but this approach is limited as the absence of a genus from the whole American continent is in itself biogeographically significant. 
TABLE 3. NEW CALEDONIAN RAINFOREST GENERA PRESENT IN OTHER AREAS

\begin{tabular}{|c|c|c|c|c|c|c|c|c|c|c|c|c|c|c|c|}
\hline tal & $\stackrel{\Xi}{\stackrel{\Xi}{4}}$ & 要 & $\frac{\sqrt{\frac{\pi}{3}}}{\frac{0}{3}}$ & 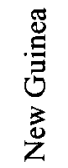 & 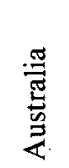 & 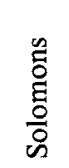 & 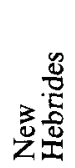 & 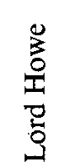 & $\begin{array}{l}\text { 豙 } \\
\stackrel{0}{0} \\
z\end{array}$ & 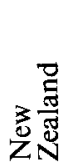 & 演 & 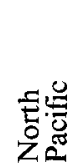 & $\begin{array}{l}\frac{\pi}{0} \\
\stackrel{0}{0} \\
\frac{0}{0} \\
0\end{array}$ & 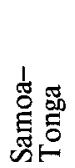 & 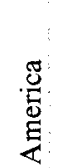 \\
\hline en & 131 & 188 & 235 & 246 & 233 & 184 & 175 & 58 & 37 & 56 & 192 & 145 & 92 & 148 & 81. \\
\hline ge & 35.9 & 51.5 & 64.3 & 67.4 & 63.8 & 50.4 & 47.9 & 15.9 & 10.1 & 15.3 & 52.6 & 39.7 & 25.2 & 40. & 2.2 \\
\hline
\end{tabular}

TABLE 4. NEW CALEDONIAN RAINFOREST GENERA (LESS THE PANTROPICAL ELEMENT) PRESENT IN OTHER AREAS

\begin{tabular}{|c|c|c|c|c|c|c|c|c|c|c|c|c|c|c|c|}
\hline 6 & 递 & $\frac{-\frac{\pi}{2}}{4}$ & 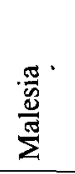 & 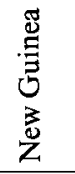 & 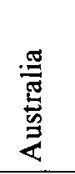 & 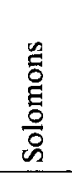 & 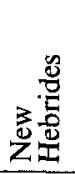 & $\begin{array}{l}0 \\
0 \\
0 \\
0 \\
0 \\
0 \\
0\end{array}$ & 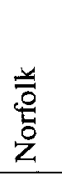 & 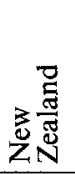 & & 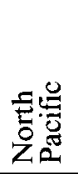 & $\begin{array}{l}\frac{\pi}{8} \\
0 \\
0 \\
2 \\
0 \\
0\end{array}$ & 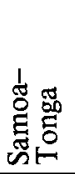 & . \\
\hline & 69 & 121 & 166 & 178 & 168 & 124 & 119 & 31 & 22 & 43 & 134 & 93 & 62 & 99 & 12 \\
\hline rcentage & 23.3 & 40.9 & 56.1 & 60.1 & 56.7 & 41.9 & 40.2 & 10.4 & 7.4 & 14.5 & 45.2 & 31.4 & 20.9 & 33.4 & 4.0 \\
\hline
\end{tabular}

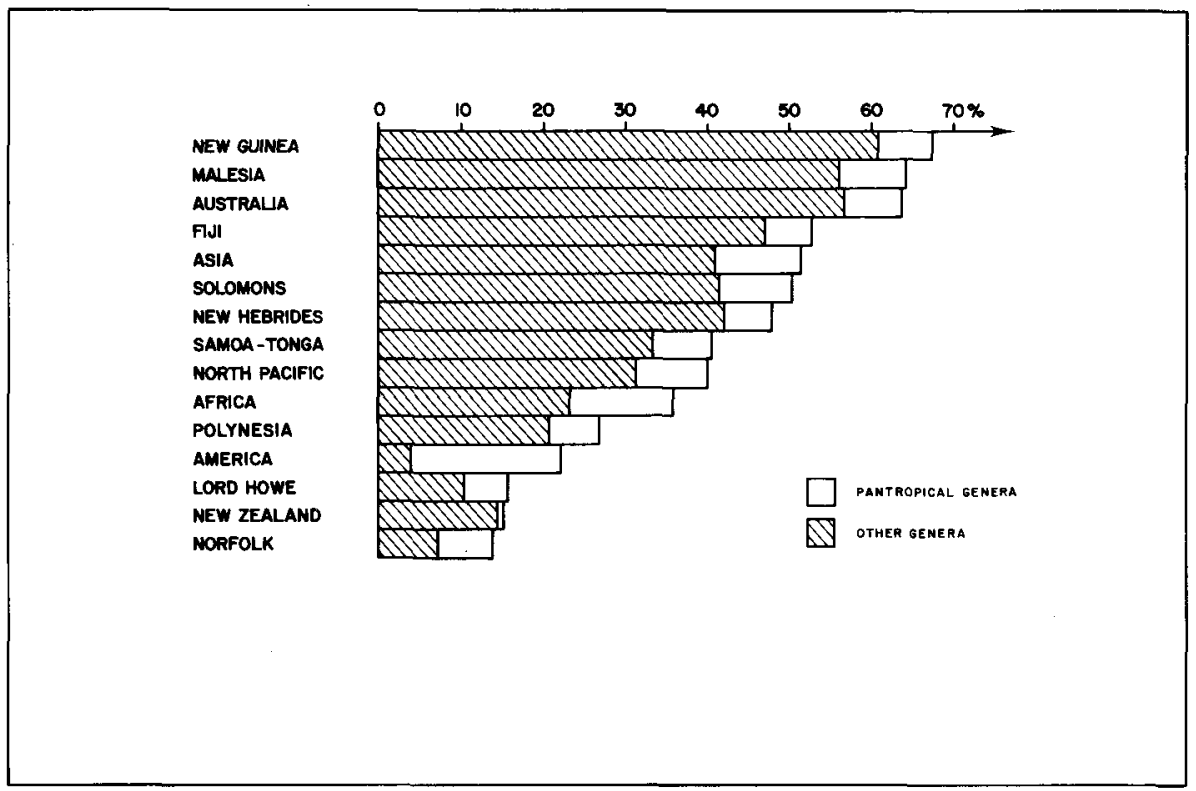

Figure 2. Graphic representation of Tables 3 and 4.

It is clear that the fewer the territories containing a taxon, the greater is its importance in showing their floristic affinity. A genus found only in two territories implies closer floristic links between them than does one common to both but occurring also in other regions, particuarly if these are extensive and geographically distant. The problem may thus be approached in another way by analysing the genera shared by New Caledonia and one only of the other 


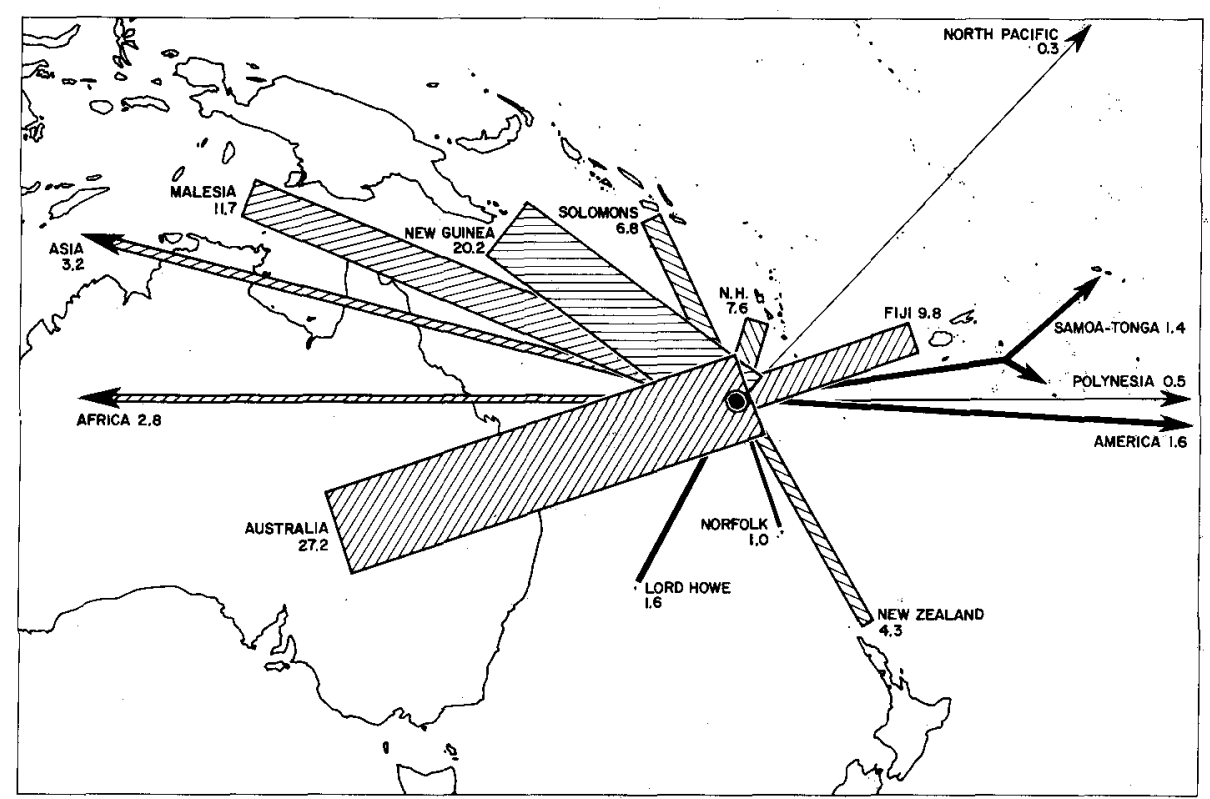

Figure 3. Floristic relationships of the New Caledonian rainforest.

phytogeographic areas considered (Table 5). In contrast with the previous results, Australia heads the list with seven genera (Argophyllum, Canarium (section Canariellum), Campynema, Duboisia, Medicosma (T. G. Hartley pers. comm.), Niemeyera, Virotia) shared with New Caledonia alone, as against three only (Hunga, Periomphale, Sloanea subgen. Antholoma) for New Guinea. Next follow with two genera each Fiji (Acmopyle, Cyphosperma) and the New Hebrides (Cyclophyllum, Dizygotheca). Africa appears in Table 5 with the genus Cunonia, which has one species, $C$. capensis, in South Africa, a striking example of relict Gondwanian distribution.

TABLE 5. GENERA LIMITED TO NEW CALEDONIA AND ONE OTHER TERRITORY

AMAR. Campynema

* BURS. Canarium (Sect. Canariellum)

ESCA. Argophyllum

PROT. Virotia

RUTA. Medicosma

SAPO. Niemeyera

SOLA. Duboisia

ALSE. Periomphale

CHRY. Hunga

* ELAE. Sloanea (s.g. Antholoma)

PALM. Cyphosperma

PODO. Acmopyle

ARAL. Dizygotheca

RUBI. Cyclophyllum

WINT. Belliolum

CUNO. Cunonia

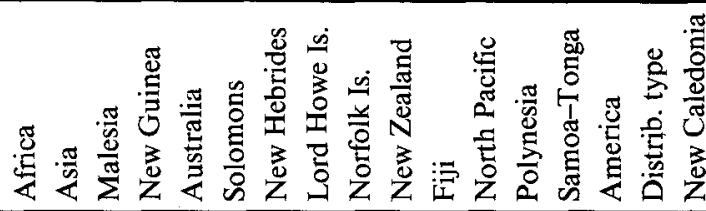

$\begin{array}{ll}\text { L } & \\ \text { H } & 2 \\ \text { H } & 2 \\ \text { B } & 2 \\ \text { I } & \\ \text { H } & \\ \text { H } & \\ \text { B } & 2 \\ \text { B } & 2 \\ \text { G } & \\ \text { L } & \\ \text { L } & \\ \text { B } & 2 \\ \text { B } & 2 \\ \text { I } & \\ \text { K } & 2\end{array}$


TABLE 6. GENERA LIMITED TO NEW CALEDONIA AND TWO OTHER TERRITORIES

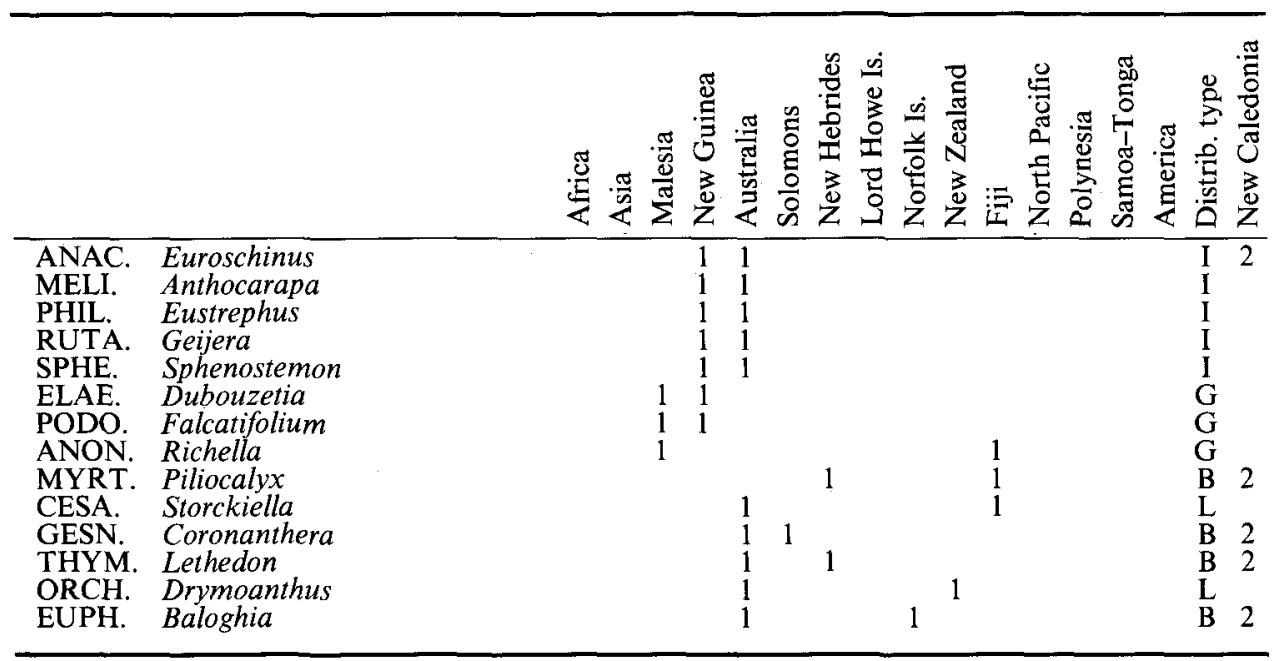

TABLE 7. GENERA LIMITED TO NEW CALEDONIA AND THREE OTHER TERRITORIES

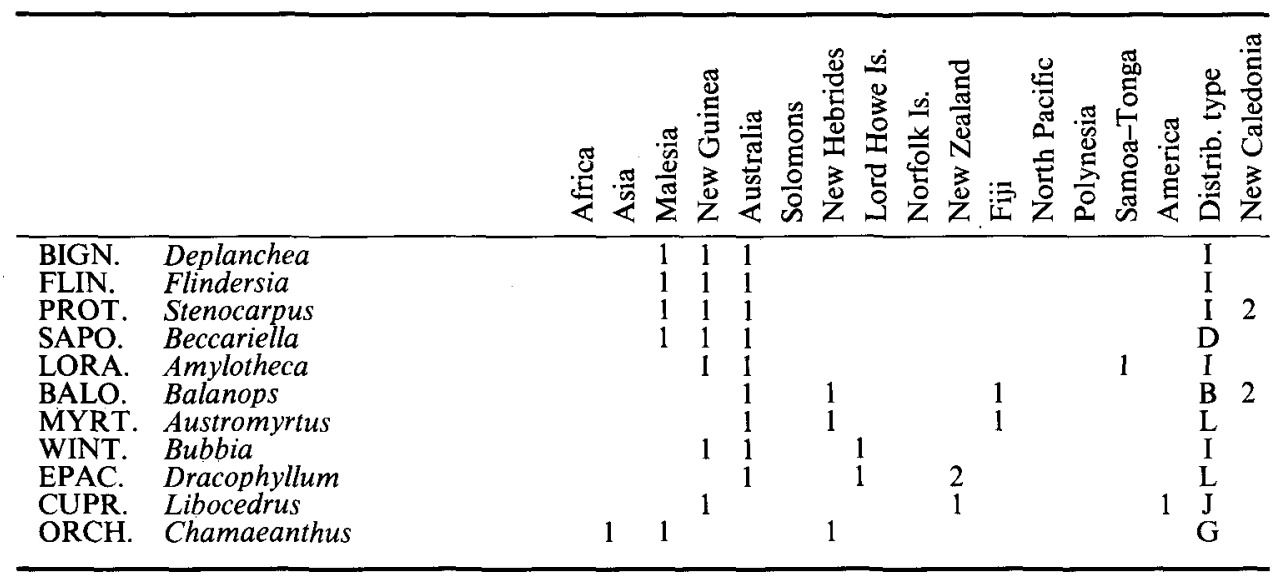

Tables $6,7,8,9$ and 10 show the genera shared exclusively by New Caledonia with two, three, four, five or six other territories. To go further would be unprofitable as we come back to the very widespread genera whose distributions are less and less significant. In each of these tables, Australia, followed fairly closely by New Guinea, has most genera in common with New Caledonia. An attempt may be made to quantify these affinities by assigning to the different territories a correlation coefficient proportional to the number of common genera and inversely proportional to the number of territories in which they occur. The five genera Anthocarapa, Euroschinus, Eustrephus, Geijera and Sphenostemon occur, for example, apart from New Caledonia, only in the two territories Australia and New Guinea, each of which is assigned the coefficient $5 / 2=2.5$. 
CUNO. Acsmithia

EUPH. Austrobuxus

ANON. Desmos

RUBI. Coelospermum

ORCH. Cleisostoma

CUNO. Geissois

MYRT. Xanthostemon

SAPO. Bureavella

ORCH. Trachoma

CORY. Corynocarpus

APOC. Pagiantha

ORCH. Acianthus

LILI. Arthropodium

FAGA. Nothofagus

ARAU. Araucaria

ORCH. Rhynchophreatia

CYPE. Costularia

ICAC. Apodytes

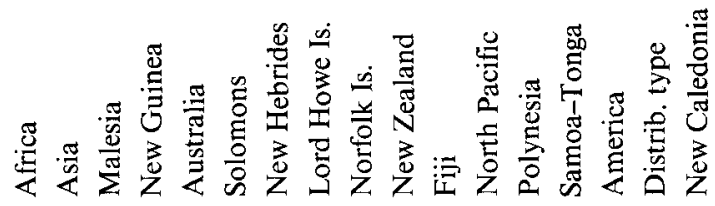

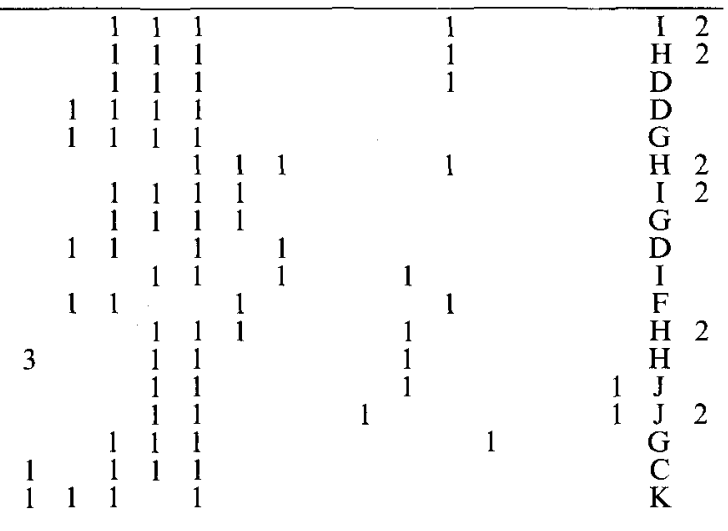

TABLE 9. GENERA LIMITED TO NEW CALEDONIA AND FIVE OTHER TERRITORIES

\begin{tabular}{|c|c|c|c|c|c|c|c|c|c|c|c|c|c|c|c|}
\hline & & : & $\cdot \frac{\pi}{\pi}$ & $\frac{\pi}{\frac{\pi}{0}}$ & 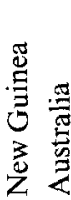 & $\frac{\mathscr{E}}{\tilde{g}}$ & 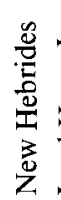 & 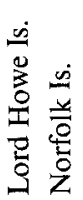 & 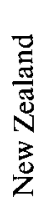 & 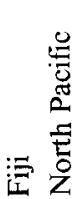 & $\frac{\pi}{\frac{\pi}{2}}$ & 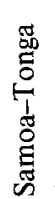 & 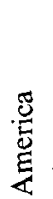 & 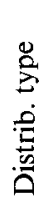 & 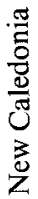 \\
\hline \multirow{3}{*}{$\begin{array}{l}\text { ARAL. } \\
\text { MYRT. }\end{array}$} & Delarbrea & & & 1 & 11 & 11 & 1 & & & & & & & B & 2 \\
\hline & Rhodomyrtus & & & & & & & & & & & & & & \\
\hline & (Archirhodomyrtus) & & 1 & 1 & 11 & 1 & & & & & & & & I & \\
\hline SAXI. & Polyosma & & 1 & 1 & 11 & 11 & & & & & & & & $\mathrm{D}$ & \\
\hline ORCH. & Pterostylis & & & 1 & 11 & & & 1 & 1 & & & & & $\mathrm{H}$ & \\
\hline SAXI. & Ouintinia & & & 1 & 11 & 1 & 1 & & 1 & & & & & $\mathrm{D}$ & \\
\hline PODO. & Prumnopitys & & & 1 & 11 & 1 & & & 1 & & & & 1 & $\mathrm{~J}$ & \\
\hline MONI. & Hedycarya & & & & 1 & 1 & 1 & & 1 & 1 & & 1 & & $\mathrm{~B}$ & 2 \\
\hline MYRT. & Tristaniopsis & & 1 & 1 & 11 & 1 & & & & 1 & & & & $\bar{D}$ & \\
\hline DILL. & Hibbertia & 1 & & 1 & 11 & & & & & 1 & & & & $\mathrm{H}$ & \\
\hline OLEA. & Olea & 2 & 1 & 1 & 1 & 1 & & 1 & & & & & & $\mathrm{C}$ & \\
\hline BIGN. & Pandorea & & & 1 & 11 & 1 & & 1 & & & & & & I & \\
\hline PODO. & Decussocarpus & & & 1 & 1 & 1 & & & & 1 & & & 1 & $\mathrm{~J}$ & \\
\hline RHIZ. & Crossostylis & & & & & 1 & 1 & & & 1 & 1 & 1 & & $\mathrm{~L}$ & \\
\hline $\mathrm{ORCH}$. & Earina & & & & & & 1 & & 1 & 1 & 1 & 1 & & $\mathrm{~L}$ & \\
\hline ORCH. & Acanthephippium & & 1 & 1 & 1 & & & & & 1 & & 1 & & $\mathrm{~F}$ & \\
\hline
\end{tabular}




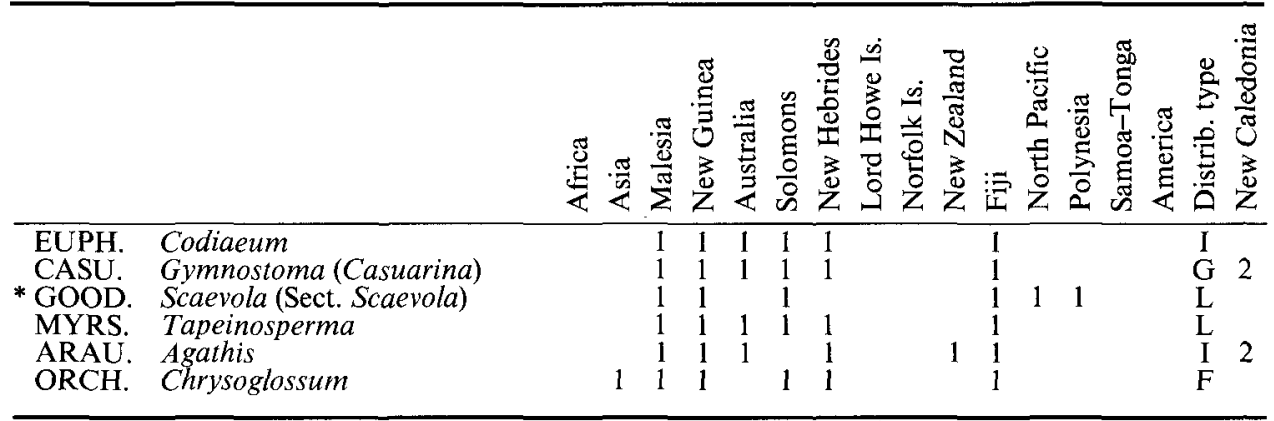

Adding all the coefficients* obtained for the territories appearing in Tables 5 to 10 gives the totals ${ }^{\dagger}$ shown in Table 11 (converted to percentages in the second column). This confirms the positions of Australia $(27 \%)$ and New Guinea $(20 \%)$ as the territories with the closest floristic affinities, followed at some distance by Malesia (12\%) and then Fiji (10\%), the New Hebrides $(8 \%)$ and the Solomons (7\%). New Zealand has only $4 \%$. It is no surprise to see thus confirmed and amplified the conclusions reached for the whole New Caledonian flora (Thorne 1965) (Table 11).

The distribution area of the great majority of genera, apart from the southern Gondwanian element (Subantarctic and Subantarctic Pacific), is to the west of New Caledonia. Two genera only, Crossostylis and Earina, are centred to the east and suggest a Pacific island origin.

TABLE 11. FLORISTIC AFFINITIES AS SHOWN BY THEIR CORRELATION COEFFICIENTS

\begin{tabular}{rlcr}
\hline Ranking & Geographical Division & Correlation Coefficient & Correlation Coefficient (\%) \\
\hline 1 & Australia & 21.19 & 27.2 \\
2 & New Guinea & 15.77 & 20.2 \\
3 & Malesia & 9.13 & 11.7 \\
4 & Fiji & 7.63 & 9.8 \\
5 & New Hebrides & 5.90 & 7.6 \\
6 & Solomons & 5.27 & 6.8 \\
7 & New Zealand & 3.22 & 4.3 \\
8 & Asia & 2.49 & 3.2 \\
9 & Africa & 2.15 & 2.8 \\
10 & Lord Howe & 1.26 & 1.6 \\
11 & America & 1.23 & 1.6 \\
12 & Samoa-Tonga & 1.13 & 1.4 \\
13 & Norfolk & 0.75 & 1.0 \\
14 & Polynesia & 0.40 & 0.5 \\
15 & North Pacific & 0.25 & 0.3 \\
& TOTAL & 77.87 & 100.0 \\
\hline
\end{tabular}

\footnotetext{
*These decrease from Table 6 to Table 10 as the denominator increases with the number of territories. The coefficients are negligible for more than six other territories.

$\dagger$ It might theoretically be objected that these coefficients depend on the delimitation of the territories chosen. Thus the exclusive presence of a genus outside New Caledonia in two units A and B of very different size (e.g. Australia and Norfolk) gives each the coefficient $1 / 2=0.5$. The large unit $A$ could be divided into $A_{1}, A_{2}, A_{3}$ (e.g. Queensland, Tasmania, the rest of Australia). If the genus occurs in all three, they have each the coefficient $1 / 4=0.25$, as also now has $B$, as against a total of 0.75 for $A$ when the coefficients for the three sub-units are added. The system chosen thus seems to favour small territories at the expense of larger areas. This does not, in fact, reflect the true situation. A genus restricted to a few phytogeographical regions is most unlikely to occur throughout a vast territory such as Africa, America, Australia or New Guinea. If the divisions are accepted it will probably occur only in $A_{1}, A_{2}, A_{3}$, which gives the same results as in the first case.
} 
Summing up, the results confirm that the rainforest genera come overwhelmingly from the north-west, particular floristic links existing with Australia and New Guinea and at a lower level with Malesia, Fiji, the New Hebrides and the Solomons, New Zealand taking only seventh place.

\section{Origin of the New Caledonian flora}

The geological history of New Caledonia must now be evoked in order to relate these results to the origin of its flora. This history, long obscure and controversial, now seems clearer thanks to recent synthetic accounts, particularly that of Paris (1981).

The main lines are as follows - during the Permian (corresponding to the oldest dated rocks of New Caledonia) and the whole secondary era, the present Norfolk Ridge represented a discontinuous insular arc (a series of islands rather than land connections) joining New Guinea to New Zealand. Palaeomagnetic data show that this arc was situated off the Queensland coast, almost parallel to the present Great Barrier Reef, thus further north and much closer to Australia than today. It suffered intense tectonic movements in the lower Cretaceous with the Rangitata Orogeny and the opening of the Tasman Sea. Dislocations followed by various foldings and metamorphic changes produced first the framework of the Chaîne Centrale and then the rest of New Caledonia in its present form. The Tertiary saw a series of submersions, especially in the Palaeocene and the middle Eocene (the date of the first reef formation which marks a warmer period), alternating with general emergences. Land areas of varying size that may be supposed to have existed near New Caledonia even during periods of general submergence would provide refuges and steppingstones for the vegetation.

A major event of the upper Eocene was the outpouring of peridotites that covered almost all of New Caledonia to a thickness of about $2000 \mathrm{~m}$. This very slow phenomenon, begun under water and continued in the atmosphere, occurred about 38 million years ago and had very important effects on plant and animal life. Several points may be emphasized:

1. The complete absence, since at least the Permian, of land connections between New Caledonia and other continental land masses explains the absence of native land mammals except bats and the great poverty in some other zoological groups - freshwater fish, amphibians, reptiles and some terrestrial invertebrates (Stevens 1977).

2. Australia (particularly the north-eastern part) and the mountains of New Guinea were close to New Caledonia throughout the Permian and for most of the secondary era (up to the lower Cretaceous). The whole Gondwanian element (the ancestors of our gymnosperms and most of our primitive angiosperms*) could thus pass readily as far as New Zealand ${ }^{\dagger}$ by short-distance dispersal mechanisms along this island arc without long water gaps. This explains the 'continental' features of a large part of the New Caledonian flora§.

\footnotetext{
*The primitive dicotyledon Homoxylon neocaledonicum found (Boureau 1952) in the Carnian of western New Caledonia appears to bring the origin of the dicotyledons back to the Triassic.

†Or in the other direction from New Zealand towards New Guinea, as at this time New Zealand must have been close to Antarctica and South America (cf. the hypothesis of southern migrations (Cranwell 1964, Raven \& Axelrod 1974)). The dominant floristic affinities with Australia, New Guinea and Malesia suggest, however, a preponderant migration from the north.

$\S$ Fournier (1874) based a similar hypothesis on the floristic affinities of New Caledonian ferns.
} 
3. Migration routes, whether north-south or inversely according to the climatic conditions at different epochs, were cut during the long isolation following the dislocations and orogenic movements. This led to a high level of endemism and in certain genera (Agathis, Araucaria, Argophyllum, Geissois, Nothofagus, Phyllanthus, Pittosporum, Psychotria, Stenocarpus, Xanthostemon, etc.) a speciation surprisingly active in view of the small surface of the island. This prolonged isolation also explains why many typically Australian taxa (phyllodineous Acacia, Banksia, Eucalyptus, Macrozamia and 10 or so forest genera of Proteaceae in the east and particularly the north-east of the continent) are absent or very poorly represented here, as are families common to Australia and New Guinea (Eupomatiaceae, Himantandraceae) or present in both though also represented further afield (Cochlospermaceae, Hamamelidaceae, Myristicaceae, Ochnaceae, Theaceae, etc.).

This ancient flora, diversified by much local evolution, received new elements that from the lower Cretaceous onwards can only have come by long-distance transport.

4. In the early Tertiary the peridotites covering most of the island with a highly selective substrate eliminated much of the ancient flora, discouraged the installation of certain modern families (e.g. Compositae, Gramineae) well adapted by light wind-borne diaspores to long-distance dispersal, their place being taken by others apparently better adapted such as Cyperaceae, and finally set off a new phase of evolution.

\section{Effect of substrate on richness in species, endemism and conservation of primitive forms}

Floristic richness (Table 12). The 1499 known rainforest species include 77 epiphytes and 64 others on whose edaphic status information is lacking. Out of the 1358 species of known edaphic status $30.4 \%$ are limited to ultrabasic rocks (U), $41.3 \%$ to other types of rock (A) and $28.3 \%$ occur on both (I). The forest flora is poorer on ultrabasic rocks $(U+I)$ than on other substrates $(A+I)$. This position is enhanced on excluding all species of types MA, MU and MI, ecologically adaptable enough to occur also in other formations, so as to consider only the strictly forest species (FA, FU and FI), which gives 535 FA species against 291 of type FU. This relative floristic poverty of the forest on ultrabasic rocks may in part be imputed to the lower surface that they cover in New Caledonia*. This factor cannot, however, account for so great a difference (little more than half as many strictly forest species), especially as conditions of altitude, topography and rainfall are equally varied in the two cases. The flora of type A also appears more specialized as it shares only 26 species with other formations such as secondary forest, thickets, savannah, sclerophyll forest, coastal forest, etc. The flora of type $U$, on the other hand, is less distinctive with 122 species found also in other formations, mostly maquis (open formations). The floristic relationships between maquis and forest on ultrabasic rocks suggest that they are linked, maquis being derived from forest at high altitudes or by disturbance.

Originality and endemism (Table 13 ). The proportion of endemics $(89.4 \%)$ for the whole rainforest flora $(F+M)$ of type $A$ is, though still very high, lower

\footnotetext{
*The area of forest on peridotite may for the main island be estimated as between $1 / 3$ and $2 / 5$ of the total. The Loyalty Islands may be neglected here as their impoverished flora contains mostly species in common with the main island.
} 
than that for type $U(98.3 \%)$; for exclusively forest species (F) the corresponding figures are $90.4 \%$ and $97.9 \%$. In absolute number, endemic species of type A (487) are not far from twice as many as those of type $U$ (285). Non-endemic forest species are also more numerous in type A (49) than in type U (six). (Fig. 4.)

TABLE 12. DISTRIBUTION OF RAINFOREST SPECIES ON DIFFERENT SUBSTRATES (percentages for 1358 species of known edaphic status)

\begin{tabular}{|c|c|c|c|c|c|c|c|c|c|}
\hline \multirow{3}{*}{ Formation } & \multicolumn{6}{|c|}{ Substrate* } & \multirow{3}{*}{$\begin{array}{c}\text { Total } \\
\mathbf{U}+\mathrm{A}+\mathrm{I}\end{array}$} & \multirow{3}{*}{$\begin{array}{c}\text { Ephiphytes } \\
\text { (species) }\end{array}$} & \multirow{3}{*}{$\begin{array}{c}\text { Total } \\
\text { U+A+I } \\
\text { epiphytes }\end{array}$} \\
\hline & \multicolumn{2}{|c|}{$\mathbf{U}$} & \multicolumn{2}{|c|}{$\mathbf{A}$} & \multicolumn{2}{|c|}{ I } & & & \\
\hline & Species & $\%$ & Species & $\%$ & Species & $\%$ & & & \\
\hline \multirow{2}{*}{$\begin{array}{l}\text { Forest } \\
\text { Mixed } \\
\text { Total } \\
\text { F+M } \\
\text { Non-epipl }\end{array}$} & $\begin{array}{l}291 \\
122\end{array}$ & $\begin{array}{r}21.4 \\
9.0\end{array}$ & $\begin{array}{r}535 \\
26\end{array}$ & $\begin{array}{r}39.4 \\
1.9\end{array}$ & $\begin{array}{l}273 \\
111\end{array}$ & $\begin{array}{r}20.1 \\
8.2\end{array}$ & $\begin{array}{r}1099 \\
259\end{array}$ & $\begin{array}{r}76 \\
1\end{array}$ & $\begin{array}{r}1175 \\
260\end{array}$ \\
\hline & $\begin{array}{c}413 \\
y \text { tes of u }\end{array}$ & $\begin{array}{l}30.4 \\
\text { ertain }\end{array}$ & $\begin{array}{c}561 \\
\text { aphic stat }\end{array}$ & 41.3 & 384 & 28.3 & 1358 & 77 & $\begin{array}{r}1435 \\
64\end{array}$ \\
\hline \multicolumn{5}{|c|}{ TOTAL rainforest species } & & & & & 1499 \\
\hline
\end{tabular}

${ }^{*} \mathrm{U}$ - species growing only on ultrabasic substrates; A - species absent from ultrabasic substrates; I - species growing on both types of substrate.

\section{TABLE 13. PROPORTION OF ENDEMIC SPECIES IN THE RAINFOREST} (percentages based on totals shown in Table 12)

\begin{tabular}{|c|c|c|c|c|c|c|c|c|c|}
\hline \multirow{3}{*}{ Formation } & \multicolumn{6}{|c|}{ Substrate* } & \multirow{3}{*}{$\begin{array}{c}\text { Total } \\
\mathbf{U}+\mathbf{A}+\mathbf{I}+\end{array}$} & \multirow{3}{*}{$\begin{array}{l}\text { Ephiphytes } \\
\text { (species) }\end{array}$} & \multirow{3}{*}{$\begin{array}{c}\text { Total } \\
\text { U+A+I } \\
\text { epiphytes }\end{array}$} \\
\hline & \multicolumn{2}{|c|}{$\mathbf{U}$} & \multicolumn{2}{|c|}{ A } & \multicolumn{2}{|c|}{ I } & & & \\
\hline & Species & $\%$ & Species & $\%$ & Species & $\%$ & & & \\
\hline $\begin{array}{l}\text { Forest } \\
\text { Mixed }\end{array}$ & $\begin{array}{l}285 \\
121\end{array}$ & $\begin{array}{l}97.9 \\
99.1\end{array}$ & $\begin{array}{r}487 \\
16\end{array}$ & $\begin{array}{l}90.4 \\
61.5\end{array}$ & $\begin{array}{r}241 \\
94\end{array}$ & $\begin{array}{l}88.2 \\
84.6\end{array}$ & $\begin{array}{r}1013 \\
231\end{array}$ & $\begin{array}{r}46 \\
0\end{array}$ & $\begin{array}{r}1059 \\
231\end{array}$ \\
\hline $\begin{array}{l}\text { Total } \\
\text { F+M } \\
\text { Non-epipl }\end{array}$ & $\begin{array}{c}406 \\
y \text { tes of } u\end{array}$ & 98.3 & $\begin{array}{c}503 \\
\text { phic sta }\end{array}$ & 89.4 & 335 & 87.2 & 1244 & 46 & $\begin{array}{r}1290 \\
55\end{array}$ \\
\hline \multicolumn{9}{|c|}{ TOTAL endemic rainforest species } & 1345 \\
\hline
\end{tabular}

*U - species growing only on ultrabasic substrates; A - species absent from ultrabasic substrates; I - species growing on both types of substrate.

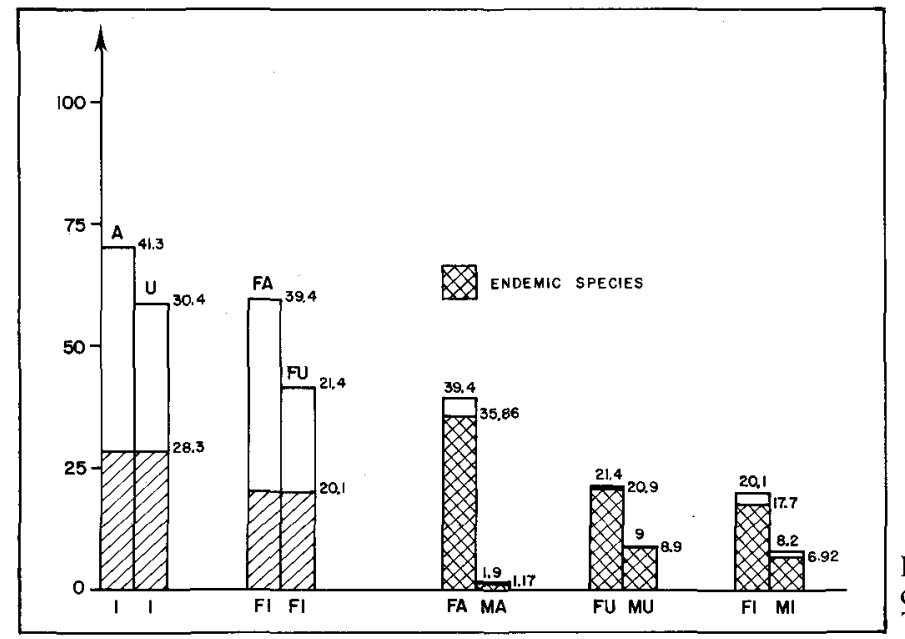

Figure 4. Relative importance of endemic species (based on Tables 12 and 13 ). 
The 108 families represented in the rainforest may be divided into five groups by their reaction $(\mathrm{A}, \mathrm{U}, \mathrm{I})$ to substrates.

1. The rainforest species of 30 families are all (italics) or mostly indifferent (I) to substrate:

Agavaceae, Alangiaceae, Alseuosmiaceae, Amaryllidaceae, Ampelidaceae, Anacardiaceae, Aquifoliaceae, Atherospermataceae, Corynocarpaceae, Dilleniaceae, Flindersiaceae, Guttiferae, Hernandiaceae, Icacinaceae, Liliaceae, Linaceae, Menispermaceae, Oleacaceae, Orchidaceae, Paracryphiaceae, Passifloraceae, Philesiaceae, Podocarpaceae, Rhamnaceae, Rutaceae, Santalaceae, Simaroubaceae, Smilacaceae, Solanaceae, Violaceae.

2. The rainforest species of 48 families are all (italics) or mostly type A:

Acanthaceae, Amborellaceae, Apocynaceae, Araceae, Araliaceae, Asclepiadaceae, Bischofiaceae, Celastraceae, Caesalpiniaceae, Chrysobalanceae, Commelinaceae, Cyperaceae, Dioscoreaceae, Ebenaceae, Elaeocarpaceae, Ericaceae, Euphorbiaceae, Flacourtiaceae, Gramineae, Hippocrateaceae, Lauraceae, Lecythidaceae, Loganiaceae, Meliaceae, Monimiaceae, Moraceae, Myrsinaceae, Myrtaceae, Nyctaginaceae, Palmae, Pandanaceae, Papilionaceae, Piperaceae, Pittosporaceae, Rhizophoraceae, Rubiaceae', Sapindaceae, Sapotaceae, Saxifragaceae, Sterculiaceae, Symplocaceae, Taxaceae, Tiliaceae, Trimeniaceae, Ulmaceae, Urticaceae, Verbenaceae, Winteraceae.

3. The rainforest species of 19 families are all (italics) or mostly type $\mathrm{U}$ :

Araucariaceae, Balanopaceae, Burseraceae, Casuarinaceae, Cunoniaceae, Cupressaceae, Epacridaceae, Escalloniaceae, Fagaceae, Flagellariaceae, Loranthaceae, Mimosaceae, Myricaceae, Nepenthaceae, Oncothecaceae, Phellinaceae, Sphenostemonaceae, Strasburgeriaceae, Thymeleaceae.

4. The two families Goodeniaceae and Triuridaceae have the same number of rainforest species in type $A$ and type $U$.

5. Eight families (Annonaceae, Balanophoraceae, Bignoniaceae, Capparaceae, Connaraceae, Cucurbitaceae, Gesneriaceae and Proteaceae) are for various reasons hard to assign definitely to the types $\mathrm{A}, \mathrm{U}$ and $\mathrm{I}$.

Three endemic families (Oncothecaceae, Phellinaceae, Strasburgeriaceae) are in the third group but Amborellaceae is in the second and Paracryphiaceae in the first group. Similarly, 22 endemic genera belong completely (as to their rainforest species) to type $\mathrm{U}$ against 17 for type $\mathrm{A}$ and 12 for type I*.

Gymnosperms are fewer in type A (4 species: Araucariaceae, Taxaceae) than in type U (13 species: Araucariaceae, Cupressaceae, Podocarpaceae); they are, however, well represented in type I (11 species: Araucariaceae, Podocarpaceae). This lack among the species of type $\mathrm{A}$ is largely compensated for by

\footnotetext{
*Type A: Amborella, Alloschmidia, Austrotaxus, Cyphophoenix, Depanthus, Exospermum, Gongrodiscus, Kentiopsis, Kibaropsis, Lavoixia, Leptostylis, Mackeea, Moratia, Pichonia, Pyriluma, Rhopalobrachium, Veillonia.

Type U: Actinokentia, Apiopetalum, Arillastrum, Botryomeryta, Campecarpus, Canacomyrica, Cerberiopsis, Clinosperma, Cocconerion, Coilochilus, Daenikera, Dendrophyllanthus, Gastrolepis, Hachettea, Morierina, Neoguillauminia, Oncotheca, Pachyplectron, Pleurocalyptus, Pritchardiopsis, Sebertia, Strasburgeria.

Type I: Amphorogyne, Campynemanthe, Chambeyronia, Clematepistephium, Cyphokentia Nemuaron, Paracryphia, Parasitaxus, Sarcomelicope, Sleumerodendron, Strobilopanax, Zieridium.
} 
the great abundance of primitive monocotyledons (Palmae, Pandanaceae) and particularly by the numerous members of archaic families the vessels of whose wood are absent or primitive (Amborellaceae, Annonaceae, Atherospermataceae, Chloranthaceae, Menispermaceae, Monimiaceae, Piperaceae, Trimeniaceae, Winteraceae). In these families, considered (Takhtajan 1969) as living fossils, type $A$ has 29 rainforest species, against 18 in type $U$ and 12 in type $I$.

Finally, if the peridotites, covering New Caledonia slowly and massively, induced a new wave of speciation (species of type $U$ ) and thus added to the originality and endemism of the flora, their contribution to its richness remains doubtful. Taking first the whole flora, it is not certain that the appearance of taxa associated with this new substrate compensated the inevitable loss of the part of the pre-Eocene flora unable to adapt to the new conditions. The evolutionary capacities of this ancient and already highly diversified flora are shown by the floristic wealth, the endemism and the abundance of unusual types present today in the forests on non-ultrabasic rocks in spite of the geological vicissitudes that they have suffered.

On a strictly comparative basis it is also clear from the floristic analyses that the peridotites, highly selective because of their peculiar chemical composition, provoke rather a relative impoverishment, not only for modern families (Boraginaceae, Compositae, Gramineae, Labiatae, Scrophulariaceae, etc.) but also for the total number of species, the endemics and the primitive forms. This casts doubt on the part often attributed to them (Virot 1956, Thorne 1965, Jaffré 1980) in conserving archaic ancestral forms. Such an effect, while it may well exist in maquis, seems, however, remarkably limited in rainforest. The persistence and the abundance of such relicts in all types of rainforest on whatever substrate stem rather from the extreme isolation of New Caledonia during its geological history.

\section{ACKNOWLEDGMENTS}

All data were analysed on a HP 9845 computer. Input and programming were carried out by M. Hoff, botanist of Centre ORSTOM, Nouméa, whom we thank for this essential collaboration. The following specialists have kindly supplied unpublished data for their respective groups: L. Allorge (P) Apocynaceae; J. W. Dawson (WELTU) - Myrtaceae (Leptospermoideae); L. L. Forman (K) - Menispermaceae; J. Jérémie (P) - Amborellaceae, Atherospermataceae, Chloranthaceae, Monimiaceae, Trimeniaceae; T. G. Hartley (CANB) - Rutaceae; H. Hürlimann (Z) - Salacia (Dicarpellum), Salaciopsis; I. Nielsen (AAU) - Mimosaceae; H. K. Airy Shaw (K) - Austrobuxus, Baloghia, Bocquilloniia, Cocconerion; B. C. Stone (KLU) - Pandanaceae; C. Tirel (P) - Elaeocarpaceae.

\section{REFERENCES}

Aubréville, A. (1964). Vues d'ensemble sur la géographie et l'écologie des Conifères et Taxacées à propos de l'ouvrage de Rudolf Florin. Adansonia ser. 2, 4: 4-7.

Aubréville, A. (1965). Les reliques de la flore des Conifères tropicaux en Australie et en Nouvelle-Calédonie. Adansonia ser. 2, 5: 481-492.

Aubréville, A. (1967). 'Flore de la Nouvelle-Calédonie et Dépendances' (Museum Natl. Hist. Nat.: Paris) vol. 1 [Sapotacées], pp. 3-168. 
Aubréville, A. (1973a). Déclin des genres de Conifères tropicaux dans le temps et l'espace. Adansonia ser. 2, 13: 5-36.

Aubréville, A. (1973b). Distribution des Conifères dans la Pangée. Adansonia ser. 2, 13: 125-133.

Aubréville, A. (1975). La flore Australo-papoue. Origine et distribution. Adansonia ser. 2, 15: 159-170.

Aubréville, A. (1976). Centres tertiaires d'origine, radiations et migrations des flores angiospermiques tropicales. Adansonia ser. 2, 16: 297-354.

Baas, P. (1975). Vegetative anatomy and affinities of Aquifoliaceae, Sphenostemon, Phelline and Oncotheca. Blumea 22: 311-407.

Balansa, B. (1873). Sur la géographie botanique de l'Océanie et de la Nouvelle-Calédonie. Bull. Soc. Hist. Nat. Toulouse 7: 327-332.

Balgooy, M. M. J. van (1960). Preliminary plant geographical analysis of the Pacific. Blumea 10: 385-430.

Balgooy, M. M. J. van (1969). A study on the diversity of island floras. Blumea 17: $139-178$.

Balgooy, M. M. J. van (1971). Plant-geography of the Pacific. Blumea, Suppl. 6: $1-222$.

Balgooy, M. M. J. van (1975) (Ed.). 'Pacific Plant Areas 3' (Rijksherbarium).

Balgooy, M. M. J. van (1976). Phytogeography. In Paijmans, K. (Ed.), 'New Guinea Vegetation' (Elsevier: Amsterdam) pp. 1-22.

Barlow, B. A. (1971). Loranthaceae. Flora of New South Wales 58: 1-35.

Baumann-Bodenheim, M. B. (1956). Uber die Beziehungen der neu-caledonischen Flora zu den tropischen und den süd-hemisphärisch - subtropischen bis - extratropischen Floren und die gürtelmässige Gliederung der Vegetations von Neu-Caledonien. Ber. Geobot. Forschungsinst. Rübel, Zürich: 64-74.

Bernard, A. (1895). 'L'Archipel de la Nouvelle-Calédonie' (Hachette: Paris) pp. 216-228.

Bernardi, L. (1979). The New Caledonian genera of Araliaceae and their relationships with those of Oceania and Indonesia. In Larsen, K. (Ed.), 'Tropical Botany' (Academic Press: London) pp. 315-325.

Boiteau, P., Allorge, L. \& Sévenet, T. (1972). Révision des Ochrosia de Nouvelle-Calédonie. Adansonia ser. 2, 12: 625-629.

Boiteau, P., Allorge, L. \& Sévenet, T. (1975). Les Melodinus de NouvelleCalédonie. Adansonia ser. 2, 15: 397-407.

Boiteau, P., Allorge, L. \& Sévenet, T. (1976a). Révision des Rauwolfia de Nouvelle-Calédonie. Adansonia ser. 2, 16: 51-61.

Boiteau, P., Allorge, L. \& Sévenet, T. (1976b). Apocynacées de NouvelleCalédonie. Révision des Alstonia. Adansonia ser. 2, 16: 465-485.

Boiteau, P. \& Allorge, L. (1978). Révision des Alyxia de Nouvelle-Calédonie. Adansonia ser. 2, 18: 443-457.

Boureau, E. (1952). Homoxylées néocalédoniennes. Colloque international sur l'évolution et la phylogénie chez les végétaux. Ann. Biol. C, 3, 2: 129-144.

Brongniart, A. (1874). Nouveaux documents sur la Flore de la NouvelleCalédonie. Compt. Rend. Hebd. Séances Acad. Sci. 79: 1442-1447.

Brousmiche, A. (1884). Considérations générales sur la végétation de la Nouvelle-Calédonie. Arch. Méd. Navale 41: 250-260.

Burbidge, N. T. (1963). 'Dictionary of Australian Plant Genera' (Angus \& Robertson: Sydney).

Carlquist, S. (1980). Anatomy and systematics of Balanopaceae. Allertonia 2: 191-246. 
Conn, B. J. (1980). A taxonomic revision of Geniostoma subg. Geniostoma (Loganiaceae). Blumea 26: 245-364.

Corner, E. J. H. (1967). Ficus in the Solomon Islands. Philos. Trans. B 253: 23-159.

Corner, E. J. H. (1970). Ficus subgen. Pharmacosycea with reference to the species of New Caledonia. Philos. Trans. B 259: 383-433.

Corner, E. J. H. (1975). Ficus in the New Hebrides. Philos. Trans. B 272: 343-367.

Cranwell, L. J. (1964). Antarctica: cradle or grave for its Nothofagus? In Cranwell, L. M. (Ed.), 'Ancient Pacific Floras: the Pollen Story' (Univ. of Hawaii Press: Honolulu) pp. 87-93.

Däniker, A. U. (1931). Ergebnisse der Reise von Dr. A. U. Däniker nach Neu-Caledonien und den Loyalitäts-Inseln (1924/25). 3. Die Loyalitäts-Inseln und ihre Vegetation. Vierteljahrsschr. Naturf. Ges. Zürich 76: 170-213.

Däniker, A. U. (1932-33). Ergebnisse der Reise von Dr. A. U. Däniker nach Neu-Caledonien und den Loyalty-Inseln (1924/6). 4. Katalog der Pteridophyta und Embryophyta siphonogama. Vierteljahrsschr. Naturf. Ges. Zürich 77: 1-235; 78: 237-395, 397-507.

Dawson, J. W. (1963). New Caledonia and New Zealand - A botanical comparison. Tuatara 11: 178-193.

Dawson, J. W. (1970). Pacific capsular Myrtaceae I. Reproductive morphology of Arillastrum gummiferum Panch. ex Baillon (New Caledonia). Blumea 18: 431-440.

Dawson, J. W. (1976). Pacific capsular Myrtaceae II. Redefinition of Metrosideros Banks ex Gaertn. and definition of infrageneric categories. Blumea 23: 7-11.

Dickison, W. C. \& Baas, P. (1977). The morphology and relationships of Paracryphia (Paracryphiaceae). Blumea 23: 417-438.

Ding Hou (1962). 'Flora Malesiana' Ser. I, vol. 6 [Celastraceae], pp. 227-291.

Ding Hou (1978). 'Flora Malesiana' Ser. I, vol. 8 [Anacardiaceae], pp. 395-548.

Florin, R. (1966). The distribution of conifer and taxad genera in time and space: additions and corrections. Acta Horti Berg. 20(6): 319-326.

Fournier, E. (1874). Sur la dispersion géographique des Fougères de la Nouvelle-Calédonic. Ann. Sci. Nat. Bot. 5ème Sér. 19: 287-299.

Fosberg, F. R., Boiteau, P. \& Sachet, M.-H. (1977). Nomenclature of the Ochrosinae: synonymy of Ochrosia Juss. and Neisosperma Raf. Adansonia ser 2, 17:23-33.

Gardner, R. O. (1978). Systematic notes on the Alseuosmiaceae. Blumea 24: 138-142.

Good, R. (1950). Madagascar and New Caledonia - a problem in plant geography. Blumea 6: 470-474.

Good, R. (1960). On the geographical relationships of the angiosperm flora of New Guinea. Bull. Brit. Mus. (Nat. Hist.), Bot. 2, 8: 205-226.

Good, R. (1964). 'The Geography of the Flowering Plants' (Longmans: London) edn 3.

Green, P. S. (1979). Observations on the phytogeography of the New Hebrides, Lord Howe Island and Norfolk Island. In Bramwell, D. (Ed.), 'Plants and Islands' (Academic Press: London).

Guillaumin, A. (1911). Catalogue des plantes phanérogames de la NouvelleCalédonie et Dépendances, Ile des Pins et Loyauté. Ann. Inst. Bot.-Géol. Colon. Marseille 2: 77-290. 
Guillaumin, A. (1921). Essai de géographie botanique de la NouvelleCalédonie. In Sarasin, F. \& Roux, J. (Eds) 'Nova Caledonia' (C. W. Kreidel: Berlin) vol. 1: 256-293.

Guillaumin, A. (1924). Le peuplement botanique de la Nouvelle-Calédonie. Compt. Rend. 48e Session. Assoc. Franç. Avancem. Sci., Liège: 953-954.

Guillaumin, A. (1928). Les régions florales du Pacifique d'aprés leur endémisme et la répartition de quelques plantes phanérogames. Proc. 3rd Pan Pacific Sci. Congr., Tokyo 1: 920-938.

Guillaumin, A. (1934). Les régions florales du Pacifique. Mém. Soc. Biogéogr. 4: 255-270.

Guillaumin, A. (1948). 'Flore Analytique et Synoptique de la NouvelleCalédonie. Phanérogames' (Office de la Recherche Scientifique Coloniale: Paris).

Guillaumin, A. (1953). Y-a-t-il réellement des rapports entre la flore calédonienne et la flore malgache? Mem. Soc. Biogéogr. Nouv. Sér. 1: 97.

Guillaumin, A. (1954). A propos de la répartition de quelques Phanérogames de Nouvelle-Calédonie et des Nouvelles-Hébrides. Compt. Rend. Sommaire Séances Soc. Biogéogr. 31: 38-40.

Guillaumin, A. (1957). Résultats scientifiques de la mission franco-suisse de botanique en Nouvelle-Calédonie (1950-1952). Mém. Mus. Natl. Hist. Nat., Sér. B, Bot. 8: 1-120.

Guillaumin, A. (1962). Résultats scientifiques de la mission franco-suisse de botanique en Nouvelle-Calédonie (1950-1952). II. Mém. Mus. Natl. Hist. Nat., Sér. B, Bot. 8: 193-330.

Guillaumin, A. (1964a). L'endémisme en Nouvelle-Calédonie. Compt. Rend. Sommaire Séances Soc. Biogéogr. 41: 67-75.

Guillaumin, A. (1964b). Résultats scientifiques de la mission franco-suisse de botanique en Nouvelle-Calédonie (1950-1952). III. Mém. Mus. Natl. Hist. Nat., Sér. B, Bot. 15: 1-96.

Guillaumin, A. (1967). Résultats scientifiques de la mission franco-suisse de botanique en Nouvelle-Calédonie (1950-1952). IV. Mém. Mus. Natl. Hist. Nat., Sér. B, Bot. 15: 97-132.

Guillaumin, A. (1974). Résultats scientifiques de la mission franco-suisse de botanique en Nouvelle-Calédonie (1950-1952). V. Mém. Mus. Natl. Hist. Nat., Sér. B, Bot. 22: 1-36.

Haas, J. E. (1977). The Pacific species of Pittosporum Banks ex Gaertn. Allertonia 1: 73-167.

Hallé, N. (1977). 'Flore de la Nouvelle-Calédonie et Dépendances' (Muséum Natl. Hist. Nat.: Paris) vol. 8 [Orchidacées], pp. 4-565.

Hansen, B. (1976). 'Flore Malesiana' Ser. I, vol. 7 [Balanophoraceae], pp. $783-806$.

Heine, H. (1976). 'Flore de la Nouvelle-Calédonie et Dépendances' (Muséum Natl. Hist. Nat.: Paris) vol. 7 [Acanthacées, Bignoniacées, Boraginacées et Solanacées], pp. 3-212.

Hoogland, R. D: (1979). Studies in the Cunoniaceae II. The genera Caldcluvia, Pullea, Acsmithia and Spiraeanthemum. Blumea 25: 492-505.

Hürlimann, H. (1955). Célastracées nouvelles ou critiques de la NouvelleCalédonie. Candollea 15: 69-78.

Jaffré, T. (1974). La végétation et la Flore d'un massif de roches ultrabasiques de Nouvelle-Calédonie: Le Koniambo. Candollea 29: 427-456. 
Jaffré, T. (1980). 'Étude Écologique de Peuplement Végétal des Sols Dérivés de Roches Ultrabasiques en Nouvelle-Calédonie'. [Coll. Trav. et Doc. de 1'ORSTOM n' 124] (ORSTOM: Paris).

Jérémie, J. (1974). A propos du genre Tarenna (Rubiaceae-Gardeniae) en Nouvelle-Calédonie. Adansonia ser. 2, 14: 473-480.

Jérémie, J. (1977). Étude des Monimiaceae: le genre Kibaropsis. Adansonia ser. 2, 17: 79-87.

Jérémie, J. (1978). Étude des Monimiaceae: révision du genre Hedycarya. Adansonia ser. 2, 18: 25-53.

Jérémie, J. (1980). Notes sur le genre Ascarina (Chloranthaceae) en NouvelleCalédonie et à Madagascar. Adansonia ser. 2, 20: 273-285.

Johnson, L. A. S . (1980). Notes on Casuarinaceae. Telopea 2: 83-84.

Johnson, L. A. S. \& Briggs, B. G. (1975). On the Proteaceae - the evolution and classification of a southern family. J. Bot. Linn. Soc. 70: 83-182.

Kanis, A. (1979). The Malesian species of Serianthes Bentham (FabaceaeMimosoideae). Brunonia 2: 289-320.

Kiew, R. (1979). Florae Malesianae Praecursores LX. The Oleaceae of Malesia II. The genus Olea. Blumea 25: 305-313.

Kostermans, A. J. G. H. (1963). The identity of Lethedon Spreng. (Thymeleaceae). Bot. Zurn. (Moscow \& Leningrad) 48: 830-833.

Kostermans, A. J. G. H. (1974). 'Flore de la Nouvelle-Calédonie et Dépendances' (Muséum Natl. Hist. Nat.: Paris) vol. 5 [Lauracées], pp. 3-123.

Kostermans, A. J. G. H. (1977). Notes on Asiatic, Pacific and Australian Diospyros (Ebenaceae). Blumea 23: 449-474.

Laubenfels, D. J. de (1972). 'Flore de la Nouvelle-Calédonie et Dépendances' (Muséum Natl. Hist. Nat.: Paris) vol. 4 [Gymnospermes], pp. 1-168.

Laubenfels, D. J. de (1978). The genus Prumnopitys (Podocarpaceae) in Malesia. Blumea 24: 189-190.

Leenhouts, P. W. (1955). The genus Canarium in the Pacific. Bernice P. Bishop Mus. Bull. 216: 1-53.

Leroy, J.-F. (1957). Sur deux amentifères remarquables de la flore asiaticopacifique et pacifique. Proc. 8th Pacific Sci. Congr. 4: 459-464.

Lescot, M. (1980). 'Flore de la Nouvelle-Calédonie et Dépendances' (Muséum Natl. Hist. Nat.: Paris) vol. 9 [Flacourtiacées], pp. 3-134.

Lobreau-Callen, D. (1975). Deux genres de Celastraceae Cassine L. et Maytenus Mol., revus à la lumiére de la palynologie. Adansonia ser. 2, 15: 215-223.

Marais, W. (1978). 'Flore des Mascareignes' (Port-Louis) vol. 182 [Dioscoréacées], pp. 1-5.

Marais, W. \& Coode, M. J. E. (1978). 'Flore des Mascareignes'. (Port-Louis) vol. 183 [Liliacées], pp. 1-41.

Markgraf, F. (1979). Florae Malesianae Praecursores LIX. Apocynaceae V. Ochrosia, Neisosperma. Blumea 25: 233-247.

Martin, H. A. (1977). The history of Ilex (Aquifoliaceae) with special reference to Australia: evidence from pollen. Austral.J. Bot. 25: 655-673.

Moldenke, H. N. (1971). 'A Fifth Summary of the Verbenaceae, Avicenniaceae, Stilbaceae, Dicrastylidaceae, Symphoremaceae, Nyctanthaceae, and Eriocaulaceae of the World as to Valid Taxa, Geographic Distribution, and Synonymy' (The Author: Wayne, New Jersey) 2 vols.

Moore, Jr., H. E. (1978). New genera and species of Palmae from New Caledonia. Gentes Herb. 11: 291-309. 
Moore, Jr., H. E. (1980). New genera and species of Palmae from New Caledonia. Gentes Herb. 12: 17-24.

Morat, Ph. \& McKee, H. S. (1977). Quelques précisions sur le Trimenia neocaledonia Bak.f. et la famille des Triméniacées en NouvelleCalédonie. Adansonia ser. 2, 17: 204-213.

Morat, Ph., Jaffré, T., Veillon, J.-M. \& MacKee, H. S. (1981). 'Les Formations Végétales' [Map 15, Atlas de la Nouvelle-Calédonie] (ORSTOM: Paris).

Nooteboom, H. P. (1980). 'Flore de la Nouvelle-Calédonie et Dépendances' (Muséum Natl. Hist. Nat.: Paris) vol. 9 [Symplocacées], pp. 135-15\&.

Pennington, T. D. \& Styles, B. T. (1975). A generic monograph of the Meliaceae. Blumea 22: 419-540.

Paris, J. P. (1981). 'Géologie de la Nouvelle-Calédonie'. Un essai de synthèse. Mém. $n^{\circ} 113$. (Bureau de Recherches géologiques et minières: Orléans), pp. 1-278.

Philipson, W. R. (1977). The identity of Arthrophyllum and Eremopanax (Araliaceae). Adansonia ser. 2, 17: 329-333.

Prance, G. T. (1979). New genera and species of Chrysobalanaceae from Malesia and Oceania. Brittonia 31: 79-88.

Raven, P. H. \& Axelrod, D. I. (1972). Plate tectonics and Australasian biogeography. Science 176: 1379-1386.

Raven, P. H. \& Axelrod, D. I. (1974). Angiosperm biogeography and past continental movements. Ann. Missouri Bot. Gard. 61: 539-673.

Raynal, J. (1973). Notes cypérologiques: 20. Un Baumea néo-calédonien nouveau. Adansonia ser. 2, 13:467-469.

Raynal, J. (1974). Notes cypérologiques: 22. Les Costularia de NouvelleCalédonie. Adansonia ser. 2, 14: 339-368.

Raynal, J. (1975a). Les Cypéracées des Nouvelles-Hébrides - résultats de l'expédition de la Royal Society aux Nouvelles-Hébrides en 1971. Adansonia ser. 2, 15: 99-1 19.

Raynal, J. (1975b). Notes cypérologiques: 23. Un nouveau Gahnia néo-calédonien. Adansonia ser. 2, 15: 189-191.

Rendle, A. B., Baker, E. G. \& Moore, S. le M. (1921). A systematic account of the plants collected in New Caledonia and the Isle of Pines by Prof. $R$. H. Compton, M.A., in 1914. Part 1. Flowering plants (angiosperms). Proc. Linn. Soc., Bot. 45: 245-417.

Rodenburg, W. F. (1971). A revision of the genus. Trimenia (Trimeniaceae). Blumea 19: 3-15.

St John, H. (1978). Revision of Joinvillea (Joinvilleaceae). Pacific Plant Studies 37. Phytologia 40: 369-374.

Schlechter, R. (1905). Pflanzengeographische Gliederung der Insel NeuKaledonien. Bot. Jahrb. Syst. 36: 1-41.

Schlechter, R. (1907-8). Beiträge zur Kenntnis der Flora von Neu-Kaledonien. Bot. Jahrb. Syst. 39: 1-274; 40: 20-45.

Scott, A. J. (1979). A Revision of Xanthomyrtus (Myrtaceae). Kew Bull. 33: $461-484$.

Scott, A. J. (1980). Notes on Myrtaceae in the Mascarenes with some recombinations for taxa from Aldabra, Malaya, New Caledonia. Kew Bull. 34: 473-498.

Shaw, H. K. A. (1971). Notes on Malesian and other Asiatic Euphorbiaceae CXXXI - new combinations and new taxa in Austrobuxus Miq. Kew Bull. 25: 506. 
Shaw, H. K. A. (1972). Notes on Malesian and other Asiatic Euphorbiaceae CLXIV. A misplaced species of Bocquillonia Baill. Kew Bull. 27: 88.

Shaw, H. K. A. (1974). Notes on Malesian and other Asiastic Euphorbiaceae CLXXV. New species of Austrobuxus Miq. with a key to the whole genus. Kew Bull. 29: 303.

Shaw, H. K. A. (1978). Notes on Malesian and other Asiatic Euphorbiaceae CCXII. Austrobuxus. Kew Bull. 33: 39.

Shaw, H. K. A. (1980). Notes on Euphorbiaceae from Indomalesia, Australia and the Pacific - CCXL Bocquillonia Baill. Kew Bull. 35: 396-398.

Sleumer, H. (1966). 'Flora Malesiana' Ser. I, vol. 6 [Ericaceae], pp. 469-668.

Sleumer, H. (1974). A concise revision of the Flacourtiaceae of New Caledonia and the Loyalty Islands. Blumea 22: 123-147.

Smith, A. C. (1955). Phanerogam genera with distributions terminating in Fiji. J. Arnold Arbor. 36: 373-392.

Smith, A. C. (1970). The Pacific as a key to flowering plant history. Harold $L$. Lyon Arboretum Lecture (University of Hawaii) 1: 1-26.

Smith, A. C. (1976). Studies of Pacific island plants, XXXIII. The genus Ascarina (Chloranthaceae) in the southern Pacific. J. Arnold Arbor. 57: $405-425$.

Smith, A. C. (1978). A precursor to a new Flora of Fiji. Allertonia 1: 347.

Smith, A. C. (1979). 'Flora Vitiensis Nova' (Pacific Tropical Garden: Hawaii) vol. I.

Soepadmo, E. (1977). ‘Flora Malesiana' Ser. I, vol. 8 [Ulmaceae], pp. 43-66.

Steenis, C. G. G. J. van (1955). Some notes on the flora of New Caledonia and reduction of Nouhuysia to Sphenostemon. Svensk Bot. Tidskr. 49: 19-23.

Steenis, C. G. G. J. van (1971). Revision of Nothofagus in New Caledonia. Adansonia ser. 2, 11:615-624.

Steenis, C. G. G. J. van (1971). Nothofagus - key genus of plant geography, in time and space, living and fossil, ecology and phylogeny. Blumea 19: 65-98.

Steenis, C. G. G. J. van (1978). The genus Periomphale in New Guinea (Caprifoliaceae). Miscellaneous botanical notes XXV. Blumea 24: $480-481$.

Stemmerik, J. F. (1964). 'Flora Malesiana' Ser. I, vol. 8 [Nyctaginaceae], pp. 450-468.

Stevens, G. R. (1977). 'Mesozoic biogeography of the South West Pacific and its Relationship to Plate Tectonics' (Intern. Symp. Geodyn. South West Pacific: Nouméa) pp. 309-326.

Stone, B. C. (1972). On the genus Pandanus (Pandanaceae) in New Caledonia. Adansonia ser. 2, 12: 409-420.

Takhtajan, A. (1969). 'Flowering Plants: Origin and Dispersal' (Oliver \& Boyd: Edinburgh).

Thorne, R. F. (1963). Biotic distribution patterns in the tropical Pacific. In 'Pacific Basin Biogeography' (Bishop Museum Press: Hawaii).

Thorne, R. F. (1965). Floristic relationships of New Caledonia. Stud. Nat. Hist. Iowa Univ. 20: 1-14.

Thorne, R. F. (1969). Floristic relationships between New Caledonia and the Solomon Islands. Philos. Trans. 255: 595-602.

Thorne, R. F. (1972). Major disjunctions in the geographic ranges of seed plants. Quart. Rev. Biol. 47: 366-411.

Tirel, C. (1977). A propos du genre Elaeocarpus en Nouvelle-Calédonie. Adansonia ser. 2, 17: 441-454. 
Tirel, C. (1980). Nouvelles espèces de Sloanea (Elaeocarpaceae) en NouvelleCalédonie. Adansonia ser. 2, 20: 91-106.

Tirel, C. \& Raynal, J. (1980). Recherches bibliographiques sur trois espèces d'Elaeocarpus (Elaeocarpacées). Adansonia ser. 2, 20: 169-177.

Villiers, J. F. (1980). 'Flore de la Nouvelle-Calédonie et Dépendances' (Muséum Natl. Hist. Nat.: Paris) vol. 9 [Icacinacées-Corynocarpacées], pp. 159-178.

Vink, W. (1977). The Winteraceae of the Old World II. Zygogynum morphology and taxonomy. Blumea 23: 219-250.

Virot, R. (1956). La végétation canaque. Mém. Mus. Natl. Hist. Nat., Sér. B, Bot. 7: 1-398.

Virot, R. (1968). 'Flore de la Nouvelle-Calédonie et Dépendances' (Muséum Natl. Hist. Nat.: Paris) vol. 2 [Protéacées], pp. 3-254.

Virot, R. (1975). 'Flore de la Nouvelle-Calédonie et Dépendances' (Muséum Natl. Hist. Nat.: Paris) vol. 6 [Epacridacées], pp. 3-161.

Whitmore, T. C. (1975). 'Tropical Rain-forests of the Far East' (Oxford Univ. Press: Oxford).

Whitmore, T. C. (1980). A monograph of Agathis. Pl. Syst. Evol. 135: 41-69.

Whitmore, T. C. \& Page, C. N. (1980). Evolutionary implications of the distribution and ecology of the tropical conifer Agathis. New Phytol. 84: $407-416$.

Wilde, W. J. J. O. de (1972). The indigenous old world passifloras. Blumea 20: $227-250$.

Willis, J. C. (1973). 'A Dictionary of the Flowering Plants and Ferns' [revised by H. K. Airy Shaw] (Cambridge Univ. Press: Cambridge) edn 8.

\section{APPENDIX 1}

List of rainforest species in New Caledonia

\section{Symbols used}

Column 1: E - Endemic

$\mathrm{P}$ - Native, non-endemic

Column 2: e - Epiphyte

Column 3: $\mathbf{M}$-Forest species also in other formations

F - Strictly forest species

Column 4: U-Species limited to ultrabasic rocks

A - Species limited to other rocks

I - Species indifferent to substrate

$\begin{array}{ll}\text { ACANTHACEAE } & \\ \text { Graptophyllum } & \\ \text { G. balansae Heine } & \mathrm{E}-\mathrm{FA} \\ \text { G. pictum (L.) Griffith } & \mathrm{P}-\mathrm{FA} \\ \text { Hemigraphis } & \\ \text { H. reptans (G. Forster) } & \\ \text { T. Anderson ex Hemsley } & \mathrm{P}-\mathrm{MA} \\ \text { Justicia } & \mathrm{E}-\mathrm{MA} \\ \begin{array}{l}\text { J. pinensis S. Moore } \\ \text { Pseuderanthemum }\end{array} & \\ \begin{array}{l}P . \text { comptonii } \mathrm{S} \text {. Moore } \\ \text { P. repandum }\end{array} & \mathrm{E}-\mathrm{MI} \\ \text { (G. Forster) Guillaumin } & \mathrm{P}-\mathrm{MI}\end{array}$

AGAVACEAE

Cordyline

C. fruticosa

(L. ex Stickman) A. Chevalier P-FI

C. neocaledonica Linden $\mathrm{E}-\mathrm{MU}$

ALANGIACEAE

Alangium

A. bussyanum (Baillon) Harms E-FI

ALSEUOSMIACEAE

Periomphale

$\begin{aligned} & P \text {. balansae } \text { Baillon } \\ & P \text {. gaultherioides }\end{aligned}$
( (Gilg \& Schlechter) Steenis E-FI

$P$. neocaledonica (Gilg \& Schlechter) Steenis E-FI $P$. pancheri Baillon $\quad \mathrm{E}-\mathrm{FI}$

AMAR YLLIDACEAE

Campynema

C. neocaledonicum Rendle

Campynemanthe C. viridiflora Baillon

AMBORELLACEAE

Amborella

A. trichopoda Baillon

AMPELIDACEAE

Cayratia

C. carnosa (Link) Gagnepain

C. japonica

(Thunberg) Gagnepain

$\mathrm{E}-\mathrm{FI}$

$\mathrm{E}-\mathrm{FI}$

E-FA

P - FA

$\mathrm{P}-\mathrm{FI}$ 


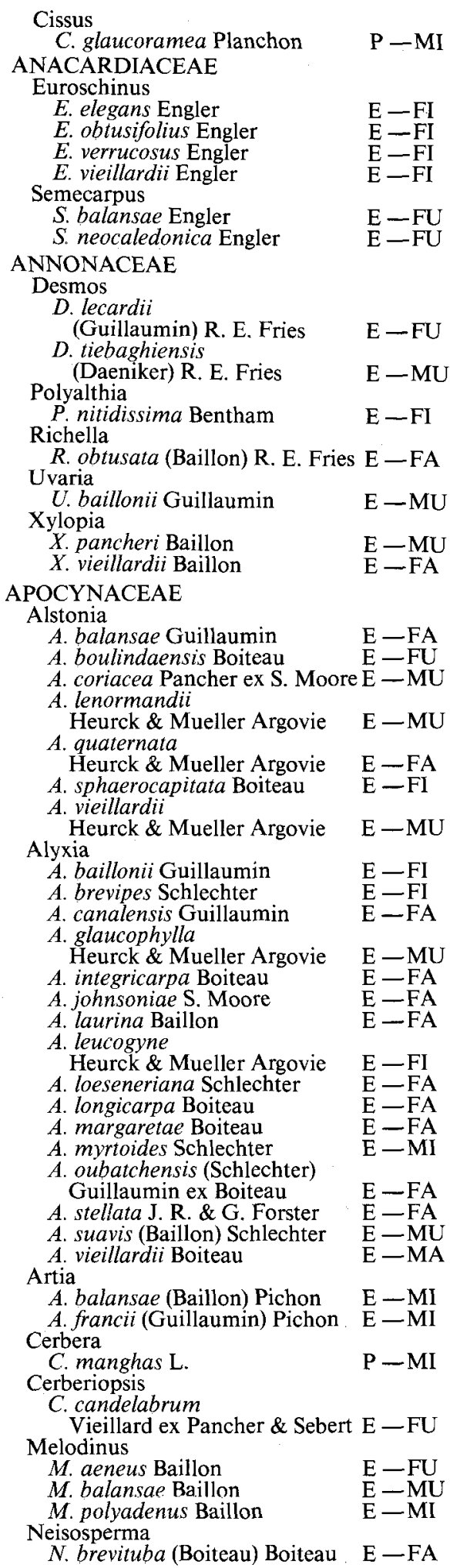

N. lifuana (Guillaumin) Boiteau E-FA

N. miana

(Baillon ex White) Boiteau E-FU

N. seveneti (Boiteau) Boiteau $\quad \mathrm{E}-\mathrm{MU}$

$N$. thiollierei

(Montrouzier) Boiteau E-FU

Ochrosia

O. balansae

(Guillaumin) Guillaumin $\quad \mathrm{E}-\mathrm{FU}$

O. grandiflora Boiteau E - FA

O. silvatica Daeniker $\quad \mathrm{E}-\mathrm{FU}$

Pagiantha

$P$. cerifera

(Sebert \& Pancher) Markgraf E-MU

Parsonsia

$\begin{array}{ll}\text { P. affinis Baillon } & \text { E-FA } \\ \text { P. catalpaecarpa Baillon } & \text { E-FA } \\ \text { P. crebriflora Baillon } & \text { E-FU } \\ \text { P. edulis Guillaumin } & \text { E-FA } \\ \text { P. flexuosa Baillon } & \text { E-MA } \\ P . \text { laxiflora Guillaumin } & \text { E-MI } \\ P \text {. linearis Baillon } & \text { E-FA } \\ P \text {. longiflora Guillaumin } & \text { E-FI } \\ P . \text { populifolia Baillon } & \text { E-FA } \\ P \text {. scabra } & \\ \quad \text { (Labillardière) Guillaumin } & \text { E-FI }\end{array}$

Rauvolfia

$R$. schumanniana

(Schlechter) Boiteau $\quad \mathrm{E}-\mathrm{FI}$

R. spathulata Boiteau $\quad \mathrm{E}-\mathrm{FU}$

AQUIFOLIACEAE

Ilex

I. sebertii Pancher $\quad$ E - MI

ARACEAE

Epipremnum

E. pinnatum (L.) Engler $\quad \mathrm{P}-\mathrm{FA}$

ARALIACEAE

Apiopetalum

A. arboreum E. G. Baker

A. glabratum Baillon

A. pennelii Viguier

$A$. velutinum Baillon

Arthrophyllum

A. angustatum

(Baillon) Philipson E-FU

A. balansae (Baillon) Philipson E-FA

A. glaberrimum (BaumannBodenheim) Philipson E - FA

A. grandifolium (Guillaumin) Philipson E-MU

A. hederoides (Baumann-
Bodenheim) Philipson $\quad \mathrm{E}-\mathrm{FU}$

A. otopyrenum

(Baillon) Philipson E-FU

A. schlechteri

(Harms) Philipson $\quad \mathrm{E}-\mathrm{FA}$

A. vieillardii

(Baillon) Philipson $\quad$ E-FA

Botryomeryta

$B$. lecardii Viguier $\quad \mathrm{E}-\mathrm{FU}$

Delarbrea

D. collina Vieillard

D. harmsi Viguier

$D$. longicarpa Viguier

D. montana Viguier

D. paradoxa Vieillard

Dizygotheca

$D$. apioidea (Baillon) Viguier

D. bailloni Viguier

$D$. coenosa Viguier

D. elegantissima (Veitch) Viguier \& Guillaumin
$P-F I$

E-FA

$\mathrm{E}-\mathrm{FU}$

$\mathrm{E}-\mathrm{FA}$

$\mathrm{E}-\mathrm{FA}$

$\mathrm{E}-\mathrm{FA}$
$\mathrm{E}=-$

$\mathrm{E}$ 

D. fagueti (Baillon) Viguier
$\mathrm{E}-\mathrm{FA}$
$D$. harmsii Viguier
$D$. lecardi Viguier
D. leptophylla Hemsley
D. ouveana Daeniker
D. parvifolia
(Pancher \& Sebert) Viguier
$D$. plerandroides Viguier
$D$. tenuifolia (Pancher) Viguier
D. toto (Baillon) Viguier
D. vieillardi (Baillon) Viguier
$M$. balansae Baillon
$M$. coriacea Baillon
$M$. denhamii Seemann
$M$. gracilis Guillaumin
$M$. microcarpa Baillon
$M$. oxylaena Baillon
$M$. pandanicarpa Guillaumin
$M$. schlechteri Harms
$M$. sonchifolia Linden \& André
$E-\overline{F A}$
$E-\overline{F A}$
$E-F A$
$\mathrm{E}-\longrightarrow$
$E-\overline{E U}$
$\mathrm{E}-\mathrm{MA}$
$\mathrm{E}-\mathrm{FU}$
$\mathrm{E}-\mathrm{FI}$
$\mathrm{E}-\mathrm{FU}$
$\mathrm{P}-\mathrm{FA}$
E-FA
$\mathrm{E}-\mathrm{FI}$
$\mathrm{E}-\mathrm{FI}$
$\mathrm{E}-\mathrm{FI}$
$\mathrm{E}-\mathrm{FA}$
$\mathrm{E}-\mathrm{FI}$

Meryta

Myodocarpus

M. brongniartii

Dubard \& Viguier

$M$. crassifolius

Dubard \& Viguier $\quad E-M U$

$M$. elegans Dubard \& Viguier $\mathrm{E}-\mathrm{FU}$

$M$. pinnatus Brongniart \& Gris $\mathrm{E}-\mathrm{MI}$

M. simplicifolius

Brongniart \& Gris $\quad$ E - MI

M. vieillardii Brongniart \& Gris $\mathrm{E}-\mathrm{FA}$

Schefflera
S. affinis Baillon
$S$. andreana Baillon
$S$. balansaeana Baillon
S. candelabrum Baillon
S. combouiensis E. G. Baker
$S$ comptonii E. G. Baker
$S$ crassipes Baillon
S. cussoniae Baillon
$S$ elongata Baillon
S. emiliana Baillon
S. gabriellae Baillon
S. golip Baillon
$S$. lerati Viguier
$S$. marcellana Baillon
$S$, nono Baillon
S. pancheri Viguier
$S$. pseudocandelabrum Viguier
$S$. veillonorum Bernardi
$S$. vieillardii Baillon
$\mathrm{E}-\mathrm{FA}$
$\mathrm{E}-\mathrm{FI}$
$\mathrm{E}-\mathrm{FU}$
$\mathrm{E}-\mathrm{FA}$
$\mathrm{E}-\mathrm{MU}$
$\mathrm{E}-\mathrm{FI}$
$\mathrm{E}-\mathrm{FU}$
$\mathrm{E}-\mathrm{FU}$
$\mathrm{E}-\mathrm{FU}$
$\mathrm{E}-\overline{\mathrm{E}}-\mathrm{FI}$
$\mathrm{E}-\mathrm{FI}$
$\mathrm{E}-\mathrm{FU}$
$\mathrm{E}-\mathrm{FA}$
$\mathrm{E}-\mathrm{FU}$
$\mathrm{E}-\mathrm{FU}$
$\mathrm{E}-\mathrm{FA}$
$\mathrm{E}-\mathrm{FA}$
$\mathrm{E}-\mathrm{FI}$

Strobilopanax

S. macrocarpus

(Baillon) Viguier

$\mathrm{E}-\mathrm{FI}$

$S$ macrocephalus (Baillon) Viguier

$\mathrm{E}-\mathrm{FI}$

Tieghemopanax

T. austrocaledonicus Viguier

$T$. balansae Viguier

$T$. bracteatus Viguier

T. lecardi Viguier

T. microbotrys Viguier

$T$. microcarpus Viguier

T. monticola Viguier

T. pulchellus Viguier

$T$. reflexus Viguier

T. sessiliflorus Viguier

$T$. suborbicularis Viguier

$\mathrm{E}-\mathrm{FI}$

$\mathrm{E}-\mathrm{FA}$

$\mathrm{E}-\mathrm{FI}$

$\mathrm{E}-\mathrm{FA}$

$\mathrm{E}-\mathrm{FI}$

$E-F A$

$\mathrm{E}-\mathrm{FA}$

$\mathrm{E}-\mathrm{FI}$

$\mathrm{E}-\mathrm{FI}$

$\mathrm{E}-\mathrm{MI}$

$\mathrm{E}-\mathrm{MU}$

ARAUCARIACEAE

Agathis

A. corbassonii deLaubenfels $\quad \mathrm{E}-\mathrm{FA}$
A. lanceolata

Lindley ex Warburg

A. montana deLaubenfels

A. moorei (Lindley) Masters

$E-F U$

$\mathrm{E}-\mathrm{FA}$

Araucaria

A. bernieri Buchholz

A. biramulata Buchholz

A. columnaris (J. R. \& G. Forster)

J. D. Hooker

A. humboldtensis Buchholz

A. montana Brongniart \& Gris

A. muelleri

(Carrière) Brongniart \& Gris

A. schmidii deLaubenfels

A. subulata Vieillard

$\mathrm{E}-\mathrm{FI}$

ASCLEPIADACEAE

Hoya

H. limoniaca S. Moore $\quad \mathrm{E}-\mathrm{FA}$

H. neocaledonica Schlechter $\mathrm{E}-\mathrm{FI}$

Marsdenia

M. brachycarpa

(Baillon) Guillaumin

$M$. lyonsioides Schlechter

$M$. nigriflora Guillaumin

$M$. oubatchensis Schlechter

$M$. pseudoparsonsia Guillaumin

$M$. raoulii Guillaumin

$M$. speciosa Baillon

$M$. tylophoroides Schlechter

$\mathrm{E}-\mathrm{FU}$

$\mathrm{E}-\mathrm{FU}$

$\mathrm{E}-\mathrm{FI}$

$\mathrm{E}-\mathrm{FU}$

$E-F U$

$\mathrm{E}-\mathrm{FA}$

$\mathrm{E}-\mathrm{FU}$

Secamone

$S$. insularis Schlechter

Tylophora

T. anisotomoides Schlechter

T. insulincola S. Moore

T. micrantha Guillaumin

T. tapeinogyne Schlechter

ATHEROSPERMATACEAE

Nemuaron

$N$. vieillardii Baillon

$E-F A$

$\mathrm{E}-\mathrm{FA}$

$\mathrm{E}-\mathrm{MU}$

$\mathrm{E}-\mathrm{MI}$

$\mathrm{E}-\mathrm{MI}$

$\mathrm{E}-\mathrm{MI}$

$E-F A$

$\mathrm{E}-\mathrm{FA}$

E - MI

$\mathrm{E}-\mathrm{FA}$

$E-F A$

$\mathrm{E}-\mathrm{FA}$

$\mathrm{E}-\mathrm{FA}$

BALANOPHORACEAE

Balanophora

B. fungosa J. R. \& G. Forster P-MA

Hachettea

$H$. austrocaledonica Baillon $\quad \mathrm{E}-\mathrm{FU}$

BALANOPACEAE

Balanops

B. balansae Baillon

$B$. microstachya Baillon

$B$. oliviformis Baillon

B. pachyphylla Baillon ex Guillaumin

$B$. pancheri Baillon

$B$, sparsiflora

(Schlechter) Hjelmqvist

B. vieillardii Baillon

$\mathrm{E}-\mathrm{FI}$

$\mathrm{E}-\mathrm{FU}$

$\mathrm{E}-\mathrm{FU}$

$\mathrm{E}-\mathrm{FU}$

$\mathrm{E}-\mathrm{FI}$

$\mathrm{E}-\mathrm{FU}$

$\mathrm{E}-\mathrm{FI}$

$\mathrm{E}-\mathrm{FI}$

BIGNONIACEAE

Deplanchea

D. sessilifolia

Vieillard ex Steenis $\quad E-M U$

D. speciosa Vieillard $\quad \mathrm{E}-\mathrm{MI}$

Pandorea

$P$. austrocaledonica

(Bureau) Seemann E-FA

BISCHOFIACEAE

Bischofia

$B$. javanica Blume

P - FA

BURSERACEAE

Canarium
C. balansae Engler
C. oleiferum Baillon
C. trifoliolatum Engler
C. whitei Guillaumin

E-FA

$\mathrm{E}-\mathrm{FU}$

$\mathrm{E}-\mathrm{FI}$

$\mathrm{E}-\mathrm{FU}$ 


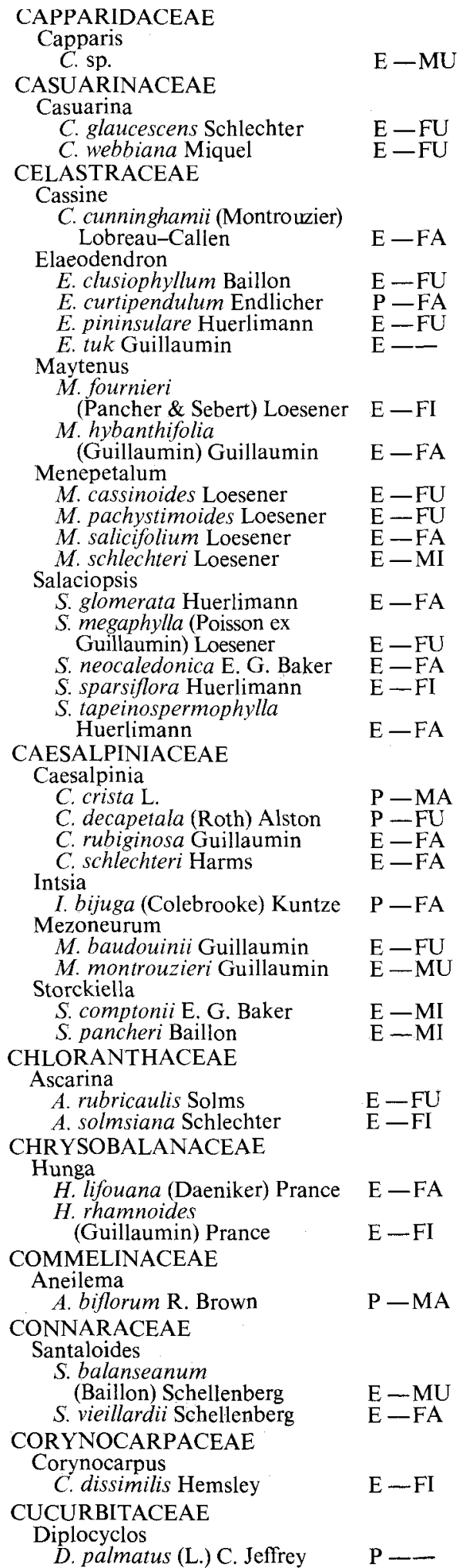

\section{CUNONIACEAE}

Acsmithia

A. austrocaledonica

(Brongniart \& Gris) Hoogland E - FI

A. laxiflora Hoogland

$\mathrm{E}-\mathrm{FA}$

A. pedunculata

(Schlechter) Hoogland $\mathrm{E}-\mathrm{FU}$

A. pubescens

(Pampanini) Hoogland E-MU

A. undulata

Codia

(Vieillard) Hoogland $\quad \mathrm{E}-\mathrm{FA}$

C. albifrons

Vieillard ex Guillaumin $\quad \mathrm{E}-\mathrm{MU}$

C. arborea

Brongniart ex Guillaumin $\mathrm{E}-\mathrm{FU}$

C. incrassata Pampanini $\quad \mathrm{E}-\mathrm{FA}$

C. montana J. R. \& G. Forster E-MI

Cunonia
C. alticola Guillaumin
C. austrocaledonica
Brongniart ex Guillaumin
$\mathrm{E}-\mathrm{FU}$
C. balansae Brongniart \& Gris
$C$. bernieri Guillaumin
C. bullata Brongniart \& Gris $\quad \mathrm{E}-\mathrm{FU}$
C. montana Schlechter $\quad \mathrm{E}-\mathrm{FI}$
C. ouaiemensis
Guillaumin \& Virot
$\begin{array}{ll}\text { Guillaumin \& Virot } & \mathrm{E}-\mathrm{MA} \\ \text { C. pterophylla Schlechter } & \mathrm{E}-\mathrm{FU}\end{array}$
C. pulchella Brongniart \& Gris E-FI
C. vieillardi Brongniart \& Gris $\mathrm{E}-\mathrm{FU}$

Geissois

G. hippocastaneifolia

Guillaumin

G. hirsuta Brongniart \& Gris

$G$. intermedia Vieillard

$G$. montana Vieillard

G. polyphylla

Lecard ex Guillaumin

$G$. racemosa Labillardière

$G$. trifoliolata Guillaumin

$G$. velutina Guillaumin

Pancheria

$P$. brunhesi Pampanin

$P$. calophylla Guillaumin

$P$. engleriana Schlechter

$P$. seberti Guillaumin

Weinmannia

\section{$W$. dichotoma \\ Brongniart \& Gris}

$W$. monticola Daeniker

$W$. paitensis Schlechter

$W$. serrata Brongniart \& Gris

$W$. thornei Guillaumin

$\mathrm{E}-\mathrm{FU}$

$\mathrm{E}-\mathrm{FU}$

$\mathrm{E}-\mathrm{FI}$

$\mathrm{E}-\mathrm{FA}$

$E-F A$

$\mathrm{E}-\mathrm{FI}$

$\mathrm{E}-\mathrm{FA}$

$\mathrm{E}-\mathrm{FU}$

$\mathrm{E}-\mathrm{FA}$

$\mathrm{E}-\mathrm{MU}$

$\mathrm{E}-\mathrm{FU}$

$\mathrm{E}-\mathrm{FI}$

$\mathrm{E}-\mathrm{FU}$

$\mathrm{E}-\mathrm{FA}$

$\mathrm{E}-\mathrm{FU}$

$P-F U$

E-FU

CUPRESSACEAE

Libocedrus

L. austrocaledonicus Brongniart \& Gris

L. yateensis Guillaumin

$\mathrm{E}-\mathrm{FU}$

CYPERACEAE

Baumea

B. veillonis Raynal $\quad \mathrm{E}-\mathrm{FU}$

Carex

C. appressa $\mathrm{R}$. Brown $\quad \mathrm{P}-\mathrm{FI}$

C. brunnea Thunberg $\quad \mathrm{P}-\mathrm{MI}$

C. dietrichiae Boeckeler $\quad \mathrm{P}-\mathrm{FI}$

$C$. indica $\mathrm{L} \quad \mathrm{P}-\mathrm{FA}$

C. inversonervosa Nelmes $\quad \mathrm{E}-\mathrm{FA}$

$C$. neurochlamys $\mathrm{F}$. Mueller $\quad \mathrm{P}-\mathrm{FA}$

Costularia

C. sylvestris Raynal $\quad \mathrm{E}-\mathrm{FU}$ 
Scleria

S. ovinux Raynal

S. rheophila Raynal

$E-F A$

Uncinia

$U$. dawsonii Hamlin

$\mathrm{E}-\mathrm{FA}$

$\mathrm{E}-\mathrm{FI}$

DILLENIACEAE

Hibbertia

H. baudouinii

Brongniart \& Gris

H. catargyrea Guillaumin

H. comptonii E. G. Baker

H. oubatchensis Schlechter

$H$. pancheri Briquet

$H$. podocarpifolia Schlechter

H. rubescens

Vieillard ex Guillaumin

Tetracera

T. scandens (L.) Merrill

DIOSCOREACEAE

Dioscorea

D bulbifera $\mathrm{L}$

EBENACEAE

Diospyros

D. austrocaledonica Hiern

D. elliptica (J. R. \& G. Forster)

P. S. Green

D. fasciculosa

(F. Mueller) F. Mueller

D. lecardii Guillaumin

$D$. leroyi Kostermans

D. macrocarpa Hiern

D. olen Hiern

D. oubatchensis Kostermans

$D$. pancheri Kostermans

D. parviflora

(Schlechter) Bakhuizen

D. rufa (Labillardière) Fosberg

D. xylopiaefolia Guillaumin

ELAEOCARPACEAE

Dubouzetia

D. elegans Brongniart \& Gris

Elaeocarpus

E. alaternoides

Brongniart \& Gris

$E$. angustifolius Blume

E. baudouinii

Brongniart \& Gris

E. biflorus Tirel

$E$. brachypodus Guillaumin

$E$ bullatus Tirel

E. castanaefolius Guillaumin

$E$. colnettianus Guillaumin

E. comptonii Baker f.

E. dognyensis Guillaumin

E. geminiflorus

Brongniart \& Gris

E. guillainit Vieillard

E. gummatus Guillaumin

$E$. hortensis Guillaumin

E. leratii Schlechter

E. moratii Tirel

E. nodosus Baker f.

E. ovigerus

Brongniart \& Gris

E. rotundifolius

Brongniart \& Gris

E. seringii Montrouzier

E. spathulatus Brongniart \& Gris

E. speciosus

Brongniart \& Gris

E. toninensis Baker F
$\mathrm{E}-\mathrm{MU}$

$\mathrm{E}-\mathrm{FU}$

$\mathrm{E}-\mathrm{FA}$

$E-F A$

$E-F I$

$\mathrm{E}-\mathrm{FI}$

E - -

$\mathrm{P}-\mathrm{FI}$

$\mathrm{P}-\mathrm{FA}$

E-FI

$\mathrm{E}-\mathrm{FU}$

$\mathrm{P}-\longrightarrow$

$\mathrm{P}-\mathrm{FA}$

$\mathrm{E}-\mathrm{FA}$

$\mathrm{E}-\mathrm{FA}$

$\mathrm{E}-\mathrm{FU}$

$\mathrm{P}-\mathrm{FA}$

$\mathrm{E}-\mathrm{FA}$

$\mathrm{E}-\mathrm{F}$

$\mathrm{E}-\mathrm{FI}$

$\mathrm{P}-\mathrm{MI}$

E - FA

E-FI

$\mathrm{E}-\mathrm{MI}$

$\mathrm{P}-\mathrm{FI}$

$\mathrm{E}-\mathrm{FU}$

$\mathrm{E}-\mathrm{FA}$

$\mathrm{E}-\mathrm{FI}$

$E-F A$

$\mathrm{E}-\mathrm{FA}$

$E-F A$

$\mathrm{E}-\mathrm{FA}$

$\mathrm{E}-\mathrm{FA}$

$\mathrm{E}-\mathrm{FA}$

$\mathrm{E}-\mathrm{FA}$

$\mathrm{E}-\mathrm{FU}$

$\mathrm{P}-\mathrm{FI}$

$\mathrm{E}-\mathrm{FU}$

$\mathrm{E}-\mathrm{FA}$

$\mathrm{E}-\mathrm{MU}$

$\mathrm{F}-\mathrm{FA}$

$\mathrm{E}-\mathrm{MI}$

$\mathrm{E}-\mathrm{MI}$

E-MI

$\mathrm{E}-\mathrm{FU}$

$\mathrm{E}-\mathrm{FA}$
E. vaccinioides $\mathrm{F}$. Mueller

$\mathrm{E}-\mathrm{FU}$

E. vieillardil

Brongniart \& Gris

E. weibeliana Tirel

E. yateensis Guillaumin

$\mathrm{E}-\mathrm{FA}$

$\mathrm{E}-\mathrm{FU}$

$\mathrm{E}-\mathrm{FU}$

Sloanea

S. billardieri

(Vieillard) A. C. Smith

$\mathrm{E}-\mathrm{FA}$

S. haplopoda

(Guillaumin) A. C. Smith

S. koghiensis Tirel

S. lepida Tirel

S. magnifolia Tirel

S. montana

(Labillardière) A. C. Smith

$S$. ramiflora Tirel

$S$. raynaliana Tirel

S. suaveolens Tirel

EPACRIDACEAE

Dracophyllum

D. ramosum

Pancher ex Brongniart \& Gris E-MU

D. verticillatum

Labillardière

Styphelia

$S$. balansae Virot

S. dammarifolia (Brongniart \& Gris) F. Mueller

S. macrocarpa

(Schlechter) Sleumer

$\mathrm{E}-\mathrm{FU}$

$\mathrm{E}-\mathrm{FA}$

$\mathrm{E}-\mathrm{FU}$

$\mathrm{E}-\mathrm{FI}$

$\mathrm{E}-\mathrm{FA}$

$\mathrm{E}-\mathrm{FA}$

$E-F A$

\section{ERICACEAE}

Agapetes

A. neocaledonica Guillaumin $\mathrm{E}-\mathrm{FA}$

ESCALLONIACEAE

Argophyllum

A. brevipetalum Guillaumin

A. ellipticum Schlechter

A. laxum Schlechter

A. nitidum J. R. \& G. Forster

A. vernicosum Daeniker

$\mathrm{E}-\mathrm{MI}$

$\mathrm{E}-\mathrm{MU}$

$\mathrm{E}-\mathrm{MU}$

$\mathrm{E}-\mathrm{MU}$

$\mathrm{E}-\mathrm{FU}$

$\mathrm{E}-\mathrm{FA}$

$\mathrm{E}-\mathrm{MU}$

$\mathrm{E}-\mathrm{FA}$

$\mathrm{E}-\mathrm{FU}$

EUPHORBIACEAE

Antidesma

A. messianianum Guillaumin

$\mathrm{E}-\mathrm{FA}$

Austrobuxus

A. brevipes A. Shaw

A. buxoides (Baillon) A. Shaw

$\mathrm{E}-\mathrm{MU}$

A. carunculatus

(Baillon) A. Shaw

A cuneatus (A. Shaw) A Shaw E-MU

A. eugeniifolius

(Guillaumin) A. Shaw

A. huerlimannii A. Shaw

A. lugubris A. Shaw

A. montisdo A. Shaw

A. ovalis A. Shaw

A. pauciflorus A. Shaw

A. rubiginosus

(Guillaumin) A. Shaw

A. vieillardii

(Guillaumin) A. Shaw

$\mathrm{E}-\mathrm{MU}$

Baloghia

$B$. alternifolia Baillon

$\mathrm{E}-\mathrm{MU}$

$\mathrm{E}-\mathrm{FU}$

$\mathrm{E}-\mathrm{FU}$

$\mathrm{E}-\mathrm{FU}$

$\mathrm{E}-\mathrm{FU}$

$\mathrm{E}-\mathrm{FU}$

$B$. anisomera Guillaumin

$B$. balansae (Baillon) Pax

$B$. bureavii (Baillon) Schlechter

$B$. lucida Endlicher

B. montana

(Mueller Argovie) Pax

$B$. pininsularis Guillaumin

B. pulchella Schlechter ex Pax

$\mathrm{E}-\mathrm{MU}$

$\mathrm{E}-\mathrm{FA}$

Bocquillonia

B. arborea A. Shaw

$B$. brevipes Mueller Argovie
$\mathrm{E}-\mathrm{MI}$

$\mathrm{E}-\mathrm{FU}$

$\mathrm{E}-\mathrm{FA}$

$\mathrm{E}-\mathrm{MU}$

$\mathrm{P}-\mathrm{FA}$

$\mathrm{E}-\mathrm{FA}$

$\mathrm{E}-\mathrm{MI}$

$\mathrm{E}-\mathrm{MU}$

$\mathrm{E}-\mathrm{FA}$ 
B. codonostylis

(Baillon) A. Shaw

$B$. grandidens Baillon

$B$. lucidula A. Shaw

$B$. nervosa A. Shaw

$B$. phenacostigma A. Shaw

B. rhomboidea (Schlechter) A. Shaw

$B$. schistophila A. Shaw

$B$. sessiliflora Baillon

B. spicata Baillon

Claoxylon

C. insulanum Mueller Argovie $\mathrm{E}-\mathrm{FA}$

Cleidion

C. claoxyloides Mueller Argovie E - FU

C. lasiophyllum

Pax \& Hoffmann

C. macarangoides Guillaumin

C. spathulatum Baillon

C. verticillatum Bailion

C. vieillardii Baillon

$E-F A$
$E-F A$
$E-F I$
$E-F I$
$E-F A$

$\mathrm{E}-\mathrm{MU}$

$\mathrm{E}-\mathrm{FA}$

$\mathrm{E}-\mathrm{FU}$

$\mathrm{E}-\mathrm{FU}$

Cleistanthus

C. stipitatus

Mueller Argovie E - FI

Cocconerion

C. balansae Baillon

$C$. minus Baillon

$\mathrm{E}-\mathrm{FU}$

$\mathrm{E}-\mathrm{FA}$

$\mathrm{E}-\mathrm{FI}$

$\mathrm{E}-\mathrm{MI}$

$\mathrm{E}-\mathrm{MI}$

Codiaeum

C. inophyllum Mueller Argovie P-FI

Croton

C. cordatulus A. Shaw $\quad \mathrm{E}-\mathrm{FU}$

Dendrophyllanthus

D. comptonii S. Moore $\quad \mathrm{E}-\mathrm{FU}$

Drypetes

D. deplanchei

(Brongniart \& Gris) Merrill E-FA

\section{Glochidion}

$\begin{array}{ll}\text { G. billardieri Baillon } & \text { E-FA } \\ \text { G. caledonicum } & \text { Mueller Argovie } \\ \text { G. glaucum } & \text { E-FA }\end{array}$

(Labillardière) Mueller Argovie E-FA

$G$. kanalense Baillon

G. macrophyllum

Mueller Argovie

G. wagapense Briquet

$\mathrm{E}-\mathrm{FU}$

$\mathrm{E}-\mathrm{MU}$

Homalanthus

H. nutans (J. R. \& G. Forster)

Guillaumin

$H$. repandus Schlechter

H. schlechteri

Pax \& Hoffman

Macaranga

$M$. alchorneoides

Pax \& Liegelsheim

$M$. coriacea Mueller Argovie

$M$. fulvescens Schlechter

$M$. insularis Schlechter

$M$. oreophila Pax \& Hoffmann

$M$. vedeliana Mueller Argovie

$M$. vieillardii Mueller Argovie

Mallotus

$M$. repandus Mueller Argovie

Neoguillauminia

N. cleopatra

(Baillon) Croizat

Phyllanthus

$P$. amieuensis Guillaumin

$P$. baladensis Baillon

$P$. balansaeanus Guillaumin

$P$. baumannii Guillaumin

$P$. bourgeoisii Baillon

$P$. bupleuroides Baillon

$\mathrm{E}-\overrightarrow{\mathrm{FI}}$

$\mathrm{P}-\mathrm{FI}$
$\mathrm{E}-\mathrm{FI}$

$\mathrm{E}-\mathrm{FI}$

$\mathrm{E}-\mathrm{FU}$

$\mathrm{E}-\mathrm{MI}$

$\mathrm{E}-\mathrm{FI}$

$\mathrm{E}-\mathrm{FA}$

$\mathrm{E}-\overline{\mathrm{FI}}$

$\mathrm{E}-\mathrm{FI}$

P - FI

$\mathrm{E}-\mathrm{FU}$

$\mathrm{E}-\mathrm{FA}$

$\mathrm{E}-\mathrm{FA}$

$\mathrm{E}-\mathrm{FU}$

$\mathrm{E}-\mathrm{FU}$

$\mathrm{E}-\mathrm{FA}$

$\mathrm{E}-\mathrm{MI}$
$P$. casearoides $\mathrm{S}$. Moore

$\mathrm{E}-\mathrm{FA}$

$P$. cataractarum

Mueller Argovie

$P$. caudatus Mueller Argovie

$P$. chamaecerasus Baillon

$P$. chrysanthus Baillon

$P$. gneissicus $\mathrm{S}$. Moore

$P$. hurlimannii Guillaumin

$P$. induratus $\mathrm{S}$. Moore

$P$. jaubertii

Vieillard ex Guillaumin

$P$. koghiensis Guillaumin

$P$. lifuensis Guillaumin

$P$. longeramosus Guillaumin

$P$. loranthoides Baillon

$P$. mareensis Guillaumin

$P$. maytenifolius S. Moore

$P$. ouveanus Daeniker

$P$. platycalyx

Mueller Argovie

$P$. rhodocladus $\mathrm{S}$. Moore

$P$. sarasinii Guillaumin

$P$. stenophyllus Guillaumin

P. sylvincola S. Moore

$P$. toninensis $\mathbf{S}$. Moore

$P$. torrentium

Mueller Argovie

$P$. trichopodus Guillaumin

$P$. umbraecolus Guillaumin

$P$. vespertilio

(Mueller Argovie) Baillon

$P$. yahouensis Schlechter

FAGACEAE

Nothofagus

$N$. aequilateralis (Baumann-

Bodenheim) Steenis

$N$. balansae (Baillon) Steenis

N. baumanniae (Baumann-

Bodenheim) Steenis

N. codonandra

(Baillon) Steenis

$N$. discoidea (BaumannBodenheim) Steenis

$\mathrm{E}-\mathrm{FU}$

$\mathrm{E}-\mathrm{MU}$

$\mathrm{E}-\mathrm{FA}$

E-MA

$\mathrm{E}-\mathrm{FA}$

$\mathrm{E}-\mathrm{MU}$

$\mathrm{E}-\mathrm{FU}$

$\mathrm{E}-\mathrm{FA}$

$\mathrm{E}-\mathrm{FU}$

E-FA

$\mathrm{E}-\mathrm{FU}$

$\mathrm{E}-\mathrm{MI}$

$\mathrm{E}-\mathrm{FA}$

$\mathrm{E}-\mathrm{FI}$

$\mathrm{E}-\mathrm{FA}$

$\mathrm{E}-\mathrm{MI}$

$\mathrm{E}-\mathrm{FA}$

E-FA

$\mathrm{E}-\mathrm{FA}$

$\mathrm{E}-\mathrm{FA}$

$\mathrm{E}-\mathrm{FA}$

$\mathrm{E}-\mathrm{FU}$

$\mathrm{E}-\mathrm{FA}$

$\mathrm{E}-\mathrm{FU}$

$\mathrm{E}-\mathrm{MI}$

$\mathrm{E}-\mathrm{FA}$

$\mathrm{E}-\mathrm{FI}$

$\mathrm{E}-\mathrm{FU}$

$\mathrm{E}-\mathrm{FU}$

$\mathrm{E}-\mathrm{FU}$

$\mathrm{E}-\mathrm{FU}$

FLACOURTIACEAE

Casearia

C. coriifolia Lescot \& Sleumer

C. lifuana Daeniker

C. puberula Guillaumin

C. silvana Schlechter

$\mathrm{E}-\mathrm{FL}$

$\mathrm{E}-\mathrm{FA}$

$\mathrm{P}-\mathrm{MI}$
Homalium

$H$. decurrens (Vieillard) Briquet $\mathrm{E}-\mathrm{MI}$

$H$. francii Guillaumin

H. guillainii

(Vieillard) Briquet

$H$. intermedium

(Vieillard) Briquet

H. polystachyum

(Vieillard) Briquet

H. rivulare (Vieillard) Briquet

$H$. sleumerianum Lescot

Lasiochlamys

L. cordifolia Sleumer

L. coriacea Sleumer

L. fasciculata

(Guillaumin) Sleumer

L. hurlimannit

(Guillaumin) Sleumer

L. koghiensis

(Guillaumin) Sleumer

L. mandjeliana Sleumer

L. pseudocoriacea Sleumer

$\mathrm{E}-\mathrm{FI}$

$\mathrm{E}-\mathrm{MI}$

$\mathrm{E}-\mathrm{FA}$

E-MI

$\mathrm{E}-\mathrm{FA}$

$\mathrm{E}-\mathrm{FA}$

$\mathrm{E}-\mathrm{FA}$

$\mathrm{E}-\mathrm{FA}$

$\mathrm{E}-\mathrm{FA}$

$\mathrm{E}-\mathrm{FU}$

$\mathrm{E}-\mathrm{MU}$

$\mathrm{E}-\mathrm{FA}$

$\mathrm{E}-\mathrm{FU}$

L. reticulata

(Schlechter) Pax \& Hoffmann E - FA 


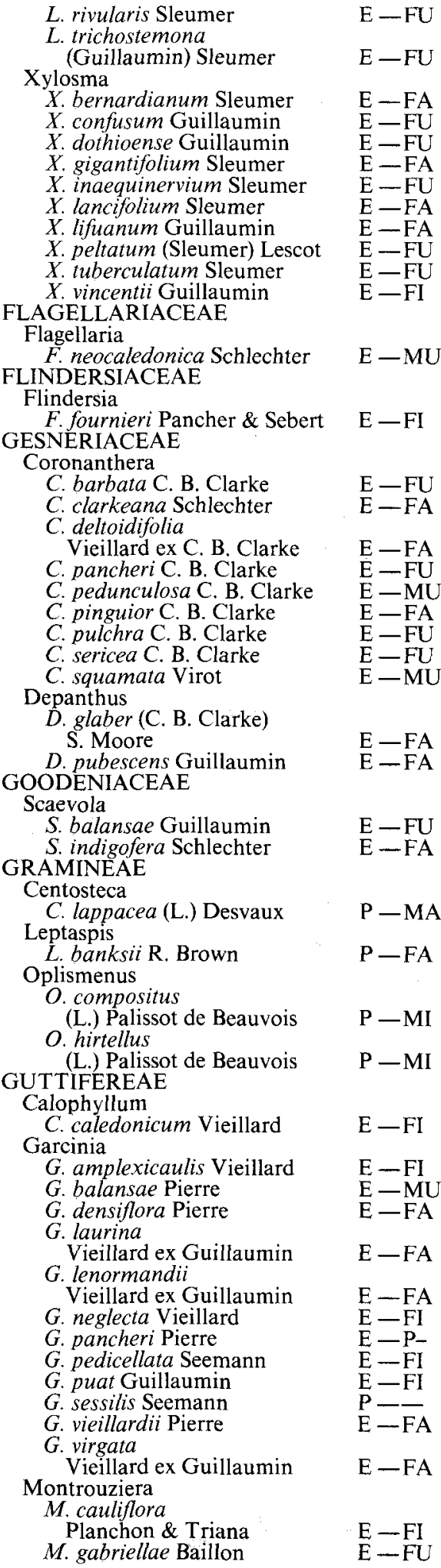

$\begin{array}{ll}\begin{array}{l}\text { M. verticillata } \\ \text { Planchon \& Triana }\end{array} & \mathrm{E}-\mathrm{MU} \\ \text { Ochrocarpus } & \\ \text { O. neurophylla } & \\ \text { (Schlechter) Steenis } & \mathrm{E}-\mathrm{FI} \\ \text { HERNANDIACEAE } & \\ \text { Hernandia } & \\ \text { H. cordigera Vieillard } & \mathrm{E}-\mathrm{FI} \\ \text { HIPPOCRATEACEAE } & \\ \text { Salacia } & \\ \text { S. bailloniana Loesener } & \mathrm{E}-\mathrm{FA} \\ \text { S. dognyensis Guillaumin } & \mathrm{E}-\mathrm{FA} \\ \text { S. neocaledonica Loesener } & \mathrm{E}-\mathrm{FU} \\ \text { S. pancheri Baillon } & \mathrm{E}-\mathrm{FI} \\ \text { S. poissoniana Loesener } & \mathrm{E}-\mathrm{FA} \\ \text { S. pronyensis Guillaumin } & \mathrm{E}-\mathrm{FU} \\ \text { ICACINACEAE } & \\ \text { Apodytes } & \\ \text { A. clusiaefolium } & \\ \text { (Baillon) Villiers } & \mathrm{E}-\mathrm{FI} \\ \text { Citronella } & \mathrm{E}-\mathrm{FA} \\ \text { C. macrocarpa Huerlimann } & \end{array}$

C. macrocarpa Huerlimann E-FA

C. sarmentosa (Baillon) Howard E - FI

Gastrolepis

G. austrocaledonica

(Baillon) Howard $\quad \mathrm{E}-\mathrm{FU}$

LAURACEAE

Adenodaphne

A. macrophylla Kostermans $\quad \mathrm{E}-\mathrm{MU}$

A. spathulata Kostermans $\quad \mathrm{E}-\mathrm{MI}$

Beilschmiedia

$B$. neocaledonica Kostermans E-MI

B. oreophila Schlechter $\quad \mathrm{E}-\mathrm{MU}$

Cryptocarya

C. aristata Kostermans $\quad \mathrm{E}-\mathrm{FA}$

C. chartacea Kostermans $\quad \mathrm{E}-\mathrm{FA}$

C. elliptica Schlechter E-FA

C. gracilis Schlechter E-FI

C. guillauminii Kostermans $\mathrm{E}-\mathrm{FU}$

C. leptospermoides Kostermans E-MI

C. lifuensis Guillaumin $\mathrm{E}-\mathrm{FA}$

C. mackeei Kostermans $\quad \mathrm{E}-\mathrm{MU}$

C. macrocarpa Guillaumin $\quad \mathrm{E}-\mathrm{FI}$

C. macrodesme Schlechter E-FA

C. odorata Guillaumin $\quad \mathrm{E}-\mathrm{MU}$

C. oubatchensis Schlechter E-FA

C. phyllostemon Kostermans $\mathrm{E}-\mathrm{FU}$

C. pluricostata Kostermans E-MI

C. schmidii Kostermans $\mathrm{E}$-FA

C. transversa Kostermans $\quad \mathrm{E}-\mathrm{FU}$

C. velutinosa Kostermans $\quad \mathrm{E}$-FA

Endiandra

E. baillonii (Pancher \& Sebert)

Guillaumin

$\mathrm{E}-\mathrm{MU}$

E. lecardii Guillaumin $\mathrm{E}-\mathrm{FA}$

E. neocaledonica Kostermans E-FI

E. polyneura Schlechter E-FA

$E$. poueboensis Guillaumin $\quad \mathrm{E}-\mathrm{FA}$

E. sebertii Guillaumin $\quad \mathrm{E}-\mathrm{FI}$

Litsea

L. lecardii Guillaumin $\quad$ E-MI

L. neocaledonica S. Moore E-FI

LECYTHIDACEAE

Barringtonia

$B$. integrifolia

(Montrouzier) Schlechter $\mathrm{E}-\mathrm{FI}$

$B$. neocaledonica Vieillard $\mathrm{E}-\mathrm{FA}$

LILIACEAE

Arthropodium

A. neocaledonicum J. G. Baker E-FI

A. paniculatum $\mathrm{R}$. Brown $\mathrm{P}$-FI

Astelia

A. neocaledonica Schlecter E e FI 
Dianella

D. ensifolia (L.) A. DC

D. javanica (Blume) Kunth

D. pendula Schlittler

$\mathrm{P}--$
$\mathrm{P}-\mathrm{FI}$
$\mathrm{E}-\mathrm{MI}$

LINACEAE

Hugonia

H. latifolia

(Vieillard) Schlechter

$H$. neocaledonica Vieillard

$H$. oreogena Schlechter

H. papillosa Guillaumin

\section{LOGANIACEAE}

Fagraea

Geniostoma

G. balansaeanum Baillon

G. celastrineum Baillon

$G$. denisflorum Baillon

$G$. erythrospermum Baillon

$G$. glaucescens Schlechter

$G$. mooreanum Conn

$G$. novaecaledoniae

Vieillard ex Baillon

G. rupestre J. R. \& G. Forster

$G$. vestitum Baillon

Neuburgia

N. neocaledonica

(Gilg \& Benedict)

$$
\begin{aligned}
& \mathrm{E}-\mathrm{MI} \\
& \mathrm{P}-\mathrm{FA} \\
& \mathrm{E}-\mathrm{FI} \\
& \mathrm{E}-\mathrm{FI}
\end{aligned}
$$

$\mathrm{E}-\mathrm{FI}$

$\mathrm{E}-\mathrm{MU}$

$\mathrm{E}-\mathrm{MI}$

$\mathrm{E}-\mathrm{MU}$

$\mathrm{E}-\mathrm{FA}$

$\mathrm{E}-\mathrm{MA}$

$\mathrm{E}-\mathrm{FA}$

$\mathrm{E}-\mathrm{FI}$

$\mathrm{E}-\mathrm{MI}$

$\mathrm{E}-\mathrm{FA}$

$\mathrm{P}-\mathrm{FI}$

\section{LORANTHACEAE}

Amyema

A. artensis

(Montrouzier) Danser $\quad \mathrm{P}-\mathrm{FU}$

A. scandens (Tieghem) Danser $\mathrm{E}-\mathrm{FU}$

Amylotheca

A. dictyophleba

(F. Mueller) Tieghem $\quad P$-FA

A. pyramidata

(Tieghem) Danser $\quad \mathrm{E}-\mathrm{FU}$

Korthalsella

$K$. amentacea (Tieghem) Danser $\mathrm{P}--$

$K$. dichotoma (Tieghem) Engler E - FI

$K$. striata Danser $\quad \mathrm{E}-\mathrm{FI}$

MELIACEAE

Aglaia

A. elaeagnoidea (Jussieu) Bentham P-FI

Amoora

$\begin{array}{ll}\text { A. balansaena A. DC. } & \mathrm{E}-\mathrm{FA} \\ \text { A. vieillardii C. DC. } & \mathrm{E}-\mathrm{FA}\end{array}$

Dysoxylum

D. albicans Vieillard ex C. DC. E-MI

D. balansaeanum C. DC. $\quad \mathrm{E}-\mathrm{FU}$

D. comptonii E. G. Baker $\quad$ E-FA

D. francii C. DC. E-FA

D. gamosepalum E. G. Baker E-FA

D. glomeratum Vieillard $\quad \mathrm{E}-\mathrm{FU}$

D. hurlimannii Guillaumin $\quad \mathrm{E}-\mathrm{FI}$

D. kouiriense Virot $\quad \mathrm{E}-\mathrm{FA}$

$\begin{array}{ll}\text { D. rufescens Vieillard } & \mathrm{E}-\mathrm{FI} \\ \text { D. vieillardii } \mathrm{C} . \mathrm{DC} . & \mathrm{E}-\mathrm{FU}\end{array}$

MENISPERMACEAE

Hypserpa

H. neocaledonica Diels

H. vieillardii Diels

$\mathrm{P}-\mathrm{FI}$

$\mathrm{E}-\mathrm{MU}$

Pachygone

$P$. loyaltiensis Diels

$P$. tomentella Diels

$\mathrm{E}-\mathrm{FI}$

Stephania

S. forsteri (A. DC.) A. Gray $\quad \mathrm{P}-\mathrm{FA}$

MIMOSACEAE

Adenanthera

A. pavonina $\mathrm{L}$.

P - FA
Albizia

A. callistemon (Montrouzier)

Guillaumin \& Beauvisage

A. granulosa Bentham

A. streptocarpa Fournier

Serianthes

$S$. melanesica Fosberg

S. sachetae Fosberg

MONIMIACEAE

Hedycarya

H. aragoensis Jérémie

$H$. baudouini Baillon

H. chrysophylla Perkins

H. cupulata Baillon

$H$. engleriana $\mathrm{S}$. Moore

$H$. parvifolia

Perkins \& Schlechter

$H$. rivularis Guillaumin

$H$. symplocoides $\mathrm{S}$. Moore

Kibaropsis

$K$. caledonica

(Guillaumin) Jérémie $\quad E-F A$

MORACEAE

Ficus

F. asperula Bureau

$F$. austrocaledonica Bureau

$F$. barraui Guillaumin

F. cataractarum

Vieillard ex Bureau

F. dzumacensis Guillaumin

$F$. heteroselis Bureau

$F$. hurlimannii Guillaumin

F. leiocarpa (Bureau) Warburg

$F$. lifouensis Corner

$F$. maialis Guillaumin

$F$. mareensis Warburg

$F$. microcarpa L.f.

F. microtophora Corner

$F$. mutabilis Bureau

$F$. nitidifolia Bureau

$F$. otophora

Corner \& Guillaumin

$F$. otophoroides Corner

$F$. pancheriana Bureau

$F$. planchonellaefolia

Guillaumin

$F$. prolixa J. R. Forster

$F$. pteroporum Guillaumin

$F$. racemigera Bureau

$F$. schlechteri Warburg

$F$. versicolor Bureau

$F$. vieillardiana Bureau

$F$ virgata Reinwardt

$F$. webbiana (Miquel) Miquel

Pseudomorus

$P$. brunoniana Bureau

$\mathrm{E}-\mathrm{FU}$

$\mathrm{E}-\mathrm{FA}$

$\mathrm{P}-\mathrm{FA}$

$\mathrm{E}-\mathrm{FU}$

$\mathrm{E}-\mathrm{FA}$

$\mathrm{E}-\mathrm{FU}$

$\mathrm{E}-\mathrm{FA}$

$\mathrm{E}-\mathrm{FA}$

$E-F A$

$\mathrm{E}-\mathrm{FU}$

$\mathrm{E}-\mathrm{FA}$

$\mathrm{E}-\mathrm{FA}$

$\mathrm{E}-\mathrm{FI}$

$\mathrm{E}-\mathrm{FI}$

E - FA

$\mathrm{E}-\mathrm{FU}$

E-FA

$\mathrm{E}-\mathrm{FA}$

$\mathrm{E}-\mathrm{FA}$

$\mathrm{E}-\mathrm{FA}$

$\mathrm{E}-\mathrm{FU}$

E - FA

$\mathrm{P}-\mathrm{MA}$

$\mathrm{E}-\mathrm{FA}$

$\mathrm{E}-\mathrm{MI}$

$\mathrm{E}-\mathrm{FU}$

E-FA

$E-F A$

$E-F A$

$\mathrm{E}-\mathrm{FU}$

$P-F A$

E - FA

$\mathrm{E}-\mathrm{FI}$

$\mathrm{E}-\mathrm{MI}$

$\mathrm{E}-\mathrm{FA}$

$\mathrm{E}-\mathrm{FA}$

$\mathrm{P}-\mathrm{MI}$

$\mathrm{E}-\mathrm{FI}$

$\mathrm{E}-\mathrm{FA}$

Sparattosyce

$S$. balansae

A. Richter ex Guillaumin $\quad \mathrm{E}-\mathrm{FA}$

$S$. dioica Bureau

$\mathrm{E}-\mathrm{FU}$

Streblus

S. sclerophyllus Corner $\quad \mathrm{E}-\mathrm{FU}$

MYRICACEAE

Canacomyrica

C. monticola Guillaumin $\quad \mathrm{E}-\mathrm{FU}$

MYRSINACEAE

Maesa

$M$. novocaledonica $\mathrm{Mez} \quad$ E-FI

Rapanea

$R$. asymmetrica $\mathrm{Mez}$

$R$. citrifolia $\mathrm{Mez}$

$R$. diminuta $\mathrm{Mez}$

$R$. grandifolia $\mathrm{S}$. Moore
$\mathrm{E}-\mathrm{MU}$

E-MI

$\mathrm{E}-\mathrm{FU}$

$\mathrm{E}-\mathrm{FU}$ 


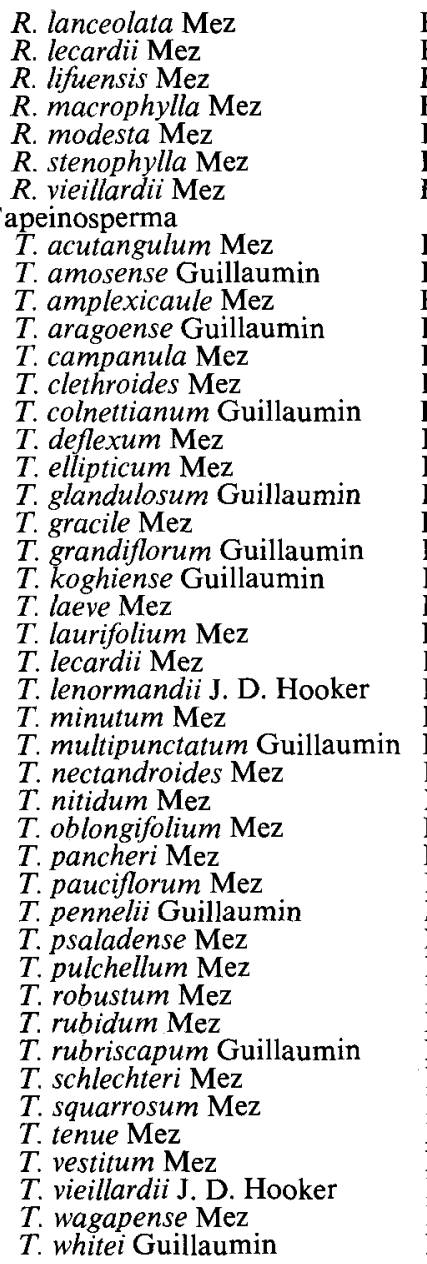

MYRTACEAE

Archirhodomyrtus

A. baladensis

(Brongniart \& Gris) Burret E-MU

A. paitensis

(Schlechter) Burret

A. viellardi

(Brongniart \& Gris) Burret $\quad \mathrm{E}-\mathrm{FU}$

Arillastrum

A. gummiferum

Pancher ex Baillon E-FU

Austromyrtus

A. ploumensis

(Daeniker) Burret $\mathrm{E}-\mathrm{FU}$

A. vieillardii

(Brongniart \& Gris) Burret $\quad \mathrm{E}-\mathrm{FA}$

Carpolepis

C. elegans

(Montrouzier) Dawson ined. E-MI

C. laurifolia (Brongniart \&

Gris) Dawson ined.

C. tardiflora Dawson ined.

Caryophyllus

$\begin{array}{ll}\text { C. amieuensis Guillaumin } & \mathrm{E}-\mathrm{FA} \\ \text { C. arboreus } \\ \text { (E. G. Baker) Guillaumin } & \mathrm{E}-\mathrm{FA} \\ \text { C. baladensis } & \end{array}$

$\mathrm{E}-\mathrm{FA}$

$\mathrm{E}-\mathrm{FA}$

$\mathrm{E}-\mathrm{FA}$

$\mathrm{E}-\mathrm{FU}$

$\mathrm{E}-\mathrm{FA}$

$\mathrm{E}-\overline{\mathrm{FI}}$

$\mathrm{E}-\overline{\mathrm{FU}}$

$E-F A$

$\mathrm{E}-\overline{\mathrm{FA}}$

E-FU

$\mathrm{E}-\mathrm{FI}$

$\mathrm{E}-\mathrm{FA}$

$\mathrm{E}-\mathrm{MI}$

$\mathrm{E}-\mathrm{FU}$

$\mathrm{E}-\mathrm{FA}$

$\mathrm{E}-\mathrm{FA}$

$\mathrm{E}-2$

$\mathrm{E}-\mathrm{FU}$

$\mathrm{E}-\mathrm{FA}$

$\mathrm{E}-\mathrm{FI}$

$\mathrm{E}-\mathrm{FA}$

$\mathrm{E}-\mathrm{FU}$

$\mathrm{E}-\mathrm{FI}$

$E-F U$
Brongniart \& Gris

$\mathrm{E}-\mathrm{FA}$

C. balansae Guillaumin

$C$. deplanchei Guillaumin

C. elegans Brongniart \& Gris

C. ellipticus Labillardière

C. garciniifolius Guillaumin

C. propinquus Guillaumin

C. pterocarpus Vieillard

C. undulatus Guillaumin

C. xanthostemifolius

Guillaumin

$\mathrm{E}-\mathrm{FI}$

$\mathrm{E}-\mathrm{FI}$

$\mathrm{E}-\mathrm{FA}$

$\mathrm{E}-\mathrm{MU}$

$\mathrm{E}-\mathrm{FA}$

$\mathrm{E}-\mathrm{FA}$

$\mathrm{E}-\overline{\mathrm{E}}-\mathrm{M}$

\section{Cleistocalyx}

C. brongniartii

(Brong. Gris) Merrill \& Perry E-FU

C. pennelii

(Guillaumin) Merrill E-FU

Cupheanthus

C. comptonii

(E. G. Baker) Guillaumin $\quad \mathrm{E}-\mathrm{FA}$

C. neocaledonicus Seemann

$\mathrm{E}-\mathrm{FA}$

C. paniensis

(E. G. Baker) Guillaumin $\quad E-F A$

C. serpentini A. Shaw

C. toninensis

Eugenia

(E. G. Baker) Guillaumin $\quad$ E-FA

E. bullata Pancher

E. colnettiana Guillaumin

E. crucigera Daeniker

$E$. daaouiensis Guillaumin

E. heckelii Pancher \& Sebert

E. ignambiensis E. G. Baker

E. myrtopsidioides Guillaumin

$E$. pronyensis Guillaumin

$E$. pterocarpa Baillon

E. sarasinii Guillaumin

$\mathrm{E}-\mathrm{FU}$

$\mathrm{E}-\mathrm{FI}$

$\mathrm{E}-\mathrm{FA}$

$\mathrm{E}-\mathrm{FU}$

$\mathrm{E}-\mathrm{FA}$

$\mathrm{E}-\mathrm{MU}$

$E-F A$

$\mathrm{E}-\mathrm{FU}$

$\mathrm{E}-\mathrm{FU}$

$\mathrm{E}-\frac{}{\mathrm{E}}$

Jambosa

J. acris Pancher $\quad \mathrm{E}-\mathrm{FU}$

J. canalensis Vieillard $\quad \mathrm{E}-\mathrm{FI}$

J. longifolia Brongniart \& Gris $\mathrm{E}-\mathrm{FA}$

$J$. nervosa Vieillard $\quad \mathrm{E}-\mathrm{FI}$

Mearnsia

$M$. brevistylis Dawson ined. $\quad \mathrm{E}-\mathrm{FI}$

Metrosideros

M. dolichandra

Schlechter ex Guillaumin

$M$. nitida Brongniart \& Gris

$M$. operculata Labillardière

$M$ oreomyrtus Daeniker

$M$. paniensis Dawson ined.

$M$. petiolata Dawson ined.

$M$. porphyrea

Schlechter ex Guillaumin

Piliocalyx

$P$. baudouini Brongniart \& Gris E-MI

$P$. bullatus Brongniart \& Gris E-FA

$P$. francii Guillaumin

$\mathrm{E}-\mathrm{FI}$

P. micranthus

Brongniart \& Gris

$P$ robustus Brongniart \& Gris E-FA

$P$. wagapensis

Brongniart \& Gris

$\mathrm{E}-\mathrm{FU}$

$\mathrm{E}-\mathrm{FI}$

$\mathrm{E}-\mathrm{MI}$

$\mathrm{E}-\mathrm{FI}$

$\mathrm{E}-\mathrm{FA}$

$\mathrm{E}-\mathrm{FI}$

Pleurocalyptus

$P$. austrocaledonicus

(Guillaumin) Dawson ined. $\quad \mathrm{E}-\mathrm{FU}$

$P$. pancheri (Brongniart \& Gris) Dawson ined.

$\mathrm{E}-\mathrm{FU}$

Syzygium

$S$. auriculatum

Brongniart \& Gris

$S$. austrocaledonicum

(Seemann) Guillaumin

$S$. conceptionis Guillaumin
E - MI

$\mathrm{E}-\mathrm{MI}$

$\mathrm{E}-\mathrm{FA}$ 
$S$. densiflorum

$\begin{array}{ll}\text { Brongniart \& Gris } & \mathrm{E}-\mathrm{FI} \\ \text { S. frutescens Brongniart \& Gris } & \mathrm{E}-\mathrm{FA}\end{array}$

$S$. koghiense Guillaumin $\mathrm{E}-\mathrm{FI}$

$S$. lateriflorum

Brongniart \& Gris $\quad$ E-FA

S. lifuanum Daeniker $\quad \mathrm{E}-\mathrm{FA}$

$S$. macranthum

Brongniart \& Gris E-FU

S. micans Brongniart \& Gris E-FA

S. microsemmifolium

Guillaumin

S. mouanum Guillaumin

$\mathrm{E}-\overline{\mathrm{FU}}$

$S$. neglectum Brongniart \& Gris $\mathbf{E}-\mathrm{FA}$

S. pseudopinnatum Daeniker E-FA

$S$. quadrangulare Guillaumin $\mathrm{E}-\mathrm{FU}$

$S$. rivulare Vieillard

S. schlechterianum

Hochreutiner

S. tenuiflorum

Brongniart \& Gris

$\mathrm{E}-\mathrm{FA}$

$\mathrm{E}-\mathrm{C}$

S. tripetalum Guillaumin

$S$. verrucosum Daeniker

S. wagapense Brongniart \& Gris E-FI

Tristaniopsis

T. polyandra

(Guillaumin) Dawson ined. E-MU

Xanthostemon

$X$. flavum (Brongniart \& Gris)

Schlechter

$X$. grisei Guillaumin

$X$. sebertii Guillaumin

$\mathrm{E}-\mathrm{FA}$

$X$. vieillardi

(Brongniart \& Gris) Niedenzu E-FA

NEPENTHĀCEAE

Nepenthes

$N$. vieillardii J. D. Hooker $\quad \mathrm{P}$-MU

NYCTAGINACEAE

Calpidia

C. gigantocarpa Heimerl

C. pancheriana Heimerl

$\mathrm{E}-\mathrm{FI}$

$\mathrm{E}-\mathrm{FA}$

Pisonia

$P$ auculeata $\mathrm{L}$

$\mathrm{P}-\mathrm{FA}$

OLEACEAE

Jasminum

J. didymum J. R. \& G. Forster P-FI

J. elatum

Pancher ex Guillaumin

$\mathrm{E}-\mathrm{FI}$

$J$. neocaledonicum Schlechter E-FI

Linociera

L. brachystachys

Olea

(Schlechter) P. S. Green E-FI

O. paniculata $\mathrm{R}$. Brown $\quad \mathrm{P}-\mathrm{FI}$

Osmanthus

O. austrocaledonicus

(Vieillard) Knoblauch E-MU

ONCOTHECACEAE

Oncotheca

$O$. balansae Baillon

O. macrocarpa

McPherson Morat \& Veillon $\mathrm{E}-\mathrm{FU}$

\section{ORCHIDACEAE}

Acanthephippium

A. vitiense $\mathrm{L}$. O. Williams $\quad \mathrm{P}-\mathrm{FI}$

Acianthus

A. atepalus $\mathrm{H}$. Reichenbach

A. bracteatus Rendle

A. confusus Guillaumin

A. corniculatus Rendle

A. cymbalariifolius

F. Mueller \& Kraenzlin

A. elegans $\mathrm{H}$. Reichenbach

$\mathrm{E}-\mathrm{FU}$

$\mathrm{E}-\mathrm{FU}$

$\mathrm{E}-\mathrm{FA}$

$\mathrm{E}-\mathrm{FI}$

$\mathrm{E}-\mathrm{FU}$
A. grandiflorus Schlechter

A. heptadactylus Kraenzlin

A. oxyglossus Schlechter

A. tenuilabris Schlechter

A. veillonis Hallé

Agrostophyllum

$A$. sp.

Anoectochilus

A. imitans Schlechter E-FI

Appendicula

A. reflexa $\mathrm{Blume}$

$\mathrm{E}-\mathrm{MU}$

$\mathrm{E}-\mathrm{FI}$

$\mathrm{E}-\mathrm{FU}$

$\mathrm{E}-\mathrm{MU}$

$\mathrm{E}-\mathrm{FU}$

$\mathrm{P}$ e FA

$\mathrm{P}$ e FI

Bulbophyllum

B. aphanopetalum Schlechter E e FI

$B$ atrorubens Schlechter E e FI

B. baladeanum J. J. Smith E e FI

$B$. betchei $\mathrm{F}$. Mueller $\quad \mathrm{P}$ e FI

B. comptonii Rendle E e FI

B. gracillimum (Rolfe) Rolfe E e FI

$B$. hexarhopalos Schlechter E e FI

$B$. keekee Hallé $\quad$ E e FI

$B$. lingulatum Rendle $\quad E$ e FI

$B$. longiflorum

DuPetit Thouars P e FI

B. lophoglottis

(Guillamin) Hallé E e FI

$B$. neocaledonicum Schlechter E e FI

$B$. ngoyense Schlechter $\quad$ E e FI

B. pachyanthum Schlechter P e FI

B. pallidiflorum Schlechter E e FI

B. polypodioides Schlechter P e FI

Calanthe

C. balansae Finet

C. langei $\mathrm{F}$. Mueller

C. neocaledonica Rendle

C. oreadum Rendle

C. triplicata (Willemet) Ames

Ceratostylis

C. micrantha Schlechter P e FI

Chamaeanthus

C. aymardii Hallé

C. begaudii Hallé

C. neocaledonicus

(Rendle) Hallé

Cheirostylis

C. montana Blume $\quad \mathrm{P}-\mathrm{MI}$

Chrysoglossum

C. neocaledonicum Schlechter E-FA

Cleisostoma

C. montanum

(J. J. Smith) Garay

$\mathrm{E}-\mathrm{FI}$

$\mathrm{E}-\mathrm{FI}$

$\mathrm{E}-\mathrm{FI}$

$\mathrm{P}-\mathrm{FI}$

E e FI

E e FI

$\mathrm{E}$ e FI

lematepistephium

C. smilacifolium

(H. Reichenbach) Hallé $\quad$ E-FI

Coelogyne

C. lycastoides

F. Mueller \& Kraenzlin P e FA

Coilochilus

C. neocaledonicus Schlechter E-MU

Corybas

C. neocaledonicus

(Schlechter) Schlechter E-FI

Cryptostylis

C. arachnites (Blume) Hasskarl P-FI

Dendrobium

D. arthrobulbum Kraenzlin E e FI

D. austrocaledonicum

Schlechter

$\mathrm{P}$ e FI
D. camaridiorum

H. Reichenbach

D. camptocentrum Schlechter

D. cleistogamum Schlechter

D. crassicaule Schlechter

D. crassifolium Schlechter
$\mathrm{E}$ e FI

$\mathrm{P}$ e FI

$\mathrm{E}$ e FI

$\mathrm{E}$ e FI

E e FI 
D. deplanchei $\mathrm{H}$. Reichenbach

D. finetianum Schlechter

D. fractiflexum Finet

D. gracilicaule F. Mueller

D. linguiforme Swartz

D. macrophyllum A. Richard

D. munificum (Finet) Hallé

D. muricatum Finet

D. ngoyense Schlechter

D. oppositifolium

(Kraenzlin) Hallé

D. pectinatum Finet

D. poissonianum Schlechter

D. sylvanum H. Reichenbach

D. virotii Guillaumin

Didymoplexis

D. minor J. J. Smith $\quad \mathrm{P}-\mathrm{FA}$

Diplocaulobium

D. ou-hinnae

Earina

(Schlechter) Kraenzlin

$E$. deplanchei $\mathrm{H}$. Reichenbach

$E$. valida $\mathrm{H}$. Reichenbach

Epipogium

E. roseum (D. Don) Lindley

Eria

E. aeridostachya

H. Reichenbach ex Lindley

E. karicouyensis Schlechter

$E$. vieillardii $\mathrm{H}$. Reichenbach

Erythrodes

E. oxyglossa Schlechter $\quad P-F U$

Eulophia

E. moratii Hallé

E. pulchra

(DuPetit Thouars) Lindley

Glomera

G. macdonaldii

(Schlechter) J. J. Smith

Gonatostylis

G. bougainvillei Hallé

$G$. vieillardii

(H. Reichenbach) Schlechter

Goodyera

G. rubicunda (Blume) Lindley

G. scripta

(H. Reichenbach) Schlechter

G. subregularis

(H. Reichenbach) Schlechter

$G$. viridiflora (Blume) Blume

Habenaria

$H$. insularis Schlechter

Hetaeria

H. discoidea Liparis

(H. Reichenbach) Schlechter

L. caespitosa Lindley

L. chalendei Finet

L. condylobulbon

H. Reichenbach

L. elliptica Wight

L. gibbosa Finet

L. laxa Schlechter

L. layardii $\mathrm{F}$. Mueller

L. phalocrocorax Hallé

L. sula Hallé

L. zosterops Hallé

Malaxis

M. taurina (H. Richenbach)

Kuntze

Megastylis

M. glandulosa

(Schlechter) Schlechter
$\mathrm{E}-\mathrm{MU}$

$\mathrm{E}$ e FI

$\mathrm{E}-\mathrm{FU}$

$\mathrm{P}$ e FI

$P$ e FI

$P$ e FI

$\mathrm{E}$ e FI

$\mathrm{E}$ e FI

$E$ e FU

$\mathrm{E}$ e FU

E e FI

$\mathrm{E}$ e FI

$\mathrm{E}$ e FI

$\mathrm{E}$ e FU

$P$ e F

$\mathrm{E}-\mathrm{MU}$

$\mathrm{P}-\mathrm{FU}$

$P$ e $F U$

$E$ e FU

$P$ e FI

$\mathrm{E}-\mathrm{FA}$

$P-F A$

$P$ e FI

$\mathrm{E}-\mathrm{FU}$

E - MI

$P-F A$

$\mathrm{E}-\mathrm{FA}$

$E-F A$

$\mathrm{P}-\mathrm{FA}$

$\mathrm{E}-\mathrm{FA}$

$\mathrm{P}-\mathrm{FA}$

$P$ e FI

$\mathrm{E}-\mathrm{MU}$

$\mathrm{P}$ e FI

$P$ e FI

$P$ e FI

$\mathrm{E}-\mathrm{MI}$

$\mathrm{P}-\mathrm{FA}$

$\mathrm{E}-\mathrm{MI}$

$\mathrm{E}-\mathrm{FU}$

$\mathrm{E}-\mathrm{FI}$

$\mathrm{E}-\mathrm{MI}$

E-FI
M. latissima

(Schlechter) Schlechter $\quad \mathrm{E}-\mathrm{FU}$

$M$. montana

(Schlechter) Schlechter E-FU

Microtatorchis

$M$. oreophila Schlechter

$M$. schlechteri Garay

$\mathrm{E}$ e FI

E e FI

Moerenhoutia

M. grandiflora

Nervilia

(Schlechter) Schlechter $\quad \mathrm{E}-\mathrm{FI}$

N. aragoana Gaudichaud $\quad \mathrm{P}-\mathrm{FA}$

N. platychila Schlechter $\quad \mathrm{P}-\mathrm{FA}$

Oberonia

O. ensiformis

(J. E. Smith) Lindley $\quad P$ e MI

O. equitans (G. Forster) Mutel $\mathrm{P}$ e FI

O. fissiglossa Hallé

$O$. neocaledonica Schlechter E e FI

Octarrhena

$O$. oberonioides

(Schlechter) Schlechter E e FI

$O$. saccolabioides

(Schlechter) Schlechter E e FI

Pachyplectron

$P$. arifolium Schlechter

$P$. neocaledonicum

Schlechter

E-FI

Peristylus

$P$. minimiflorus

(Kraenzlin) Hallé

$P$. ngoyensis (Schlechter) Hallé

Phajus

$P$. daenikeri Kraenzlin

$P$. neocaledonicus Rendle

$P$. robertsii $\mathrm{F}$. Mueller

Pholidota

P. pallida Lindley

Phreatia

P. hypsorhynchos Schlechter

$P$. neocaledonica Schlechter

$P$. oubatchensis Schlechtor

P. pachyphylla Schlechtci

$P$. paleata $\mathrm{H}$. Reichenbach

$P$. sublata Hallé

Pristiglottis

P. montana (Schlechter)

Cretziou \& J. J. Smith

Pterostylis

$P$. bureaviana Schlechter

$P$. curta R. Brown

Rhynchophreatia

R. micrantha

(A. Richard) Hallé

$\mathrm{E}-\mathrm{MU}$

$\mathrm{E}-\mathrm{FA}$

$\mathrm{E}-\mathrm{FI}$

$\mathrm{E}-\mathrm{FU}$

E-FA

$\mathrm{E}-\mathrm{FI}$

$\mathrm{P}$ e FI

$\mathrm{E}$ e FI

$\mathrm{E}$ e FI

$\mathrm{E}$ e FI

$\mathrm{P}$ e FI

$\mathrm{E}$ e $\mathrm{FI}$

$\mathrm{E}$ e FI

$\mathrm{P}-\mathrm{FI}$

$\mathrm{E}-\mathrm{FU}$

$\mathrm{P}-\mathrm{FA}$

Sarcochilus

S. hillii

(F. Mueller) F. Mueller

S. koghiensis Schlechter

Schoenorchis

S. micrantha

Reinwardt ex Blume

Spathoglottis

S. petri H. Reichenbach

Spiranthes

$S$. sinensis (Persoon) Ames

Taeniophyllum

T. graptolitum Hallé

T. trachypus Schlechter

$P$ e FI

$P$ e FI

E e FI

$\mathrm{P}$ e FI

$\mathrm{P}-\mathrm{FA}$

$\mathrm{P}-\mathrm{MI}$

E e FI

E e FI

Thrixspermum

$T$. sp.

Trachoma

T. subluteum (Rupp) Garay
$\mathrm{P}$ e FI

$\mathrm{P}$ e FI 
Tropidia

T. viridifusca Kraenzlin $\quad$ E-FA

Zeuxine

Z. francii Schlechter

$Z$. vieillardii

PALMAE

(H. Reichenbach) Schlechter E-FA

Actinokentia

$A$. divaricata Dammer

A. huerlimannii H. E. Moore

E-FU

$\mathrm{E}-\mathrm{FU}$

Alloschmidia

A. glabrata
(Beccari) H. E. Moore
Basselinia
B. deplanchei Vieillard
B. eriostachys Beccari
B. gracilis Vieillard
B. pancheri Vieillard
B. surculosa Beccari
B. tomentosa Beccari
B. velutina Beccari

Brongniartikentia

$B$. lanuginosa $\mathrm{H}$. E. Moore

$B$. vaginata

(Brongniart) Beccari

Burretiokentia

$B$. hapala H. E. Moore

$B$. vieillardii $\mathrm{H}$. E. Moore

Campercarpus

C. fulcitus Wendland

Chambeyronia

C. lepidota H. E. Moore

C. macrocarpa Vieillard

Clinosperma

C. bractealis Beccari

Cyphokentia

C. macrostachya Brongniart

Cyphophoenix

C. elegans Wendland

C. nucele $\mathrm{H}$. E. Moore

Cyphosperma

C. balansae Wendland ex

Bentham \& J. D. Hooker

Kentiopsis

$K$. olivaeformis Brongniart

Lavoixia

L. macrocarpa H. E. Moore

Mackeea

$M$. magnifica $\mathrm{H}$. E. Moore

Moratia

$M$. cerifera $\mathrm{H}$. E. Moore

Pritchardiopsis

$P$. jeanneneyi Beccari $\quad \mathrm{E}-\mathrm{FU}$

Veillonia

$V$ alba H. E. Moore

PANDANACEAE

Freycinetia

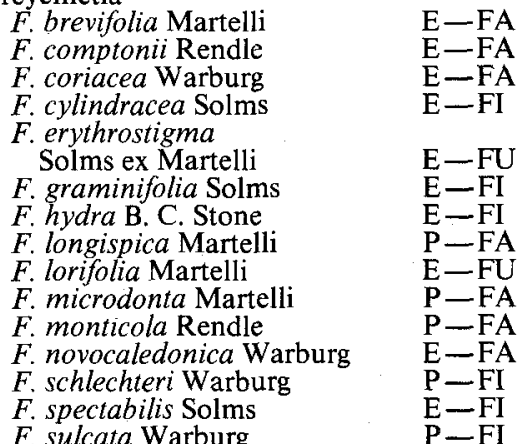

$\mathrm{E}-\mathrm{FA}$

$\mathrm{E}-\mathrm{FA}$

$\mathrm{E}-\mathrm{FI}$

E-FI

$\mathrm{E}-\mathrm{FU}$

$\mathrm{E}-\mathrm{FU}$

$\mathrm{E}-\mathrm{FA}$

$\mathrm{E}-\mathrm{FI}$

E-FA

$\mathrm{E}-\mathrm{FU}$

E-FA

$\mathrm{E}-\mathrm{FI}$

$\mathrm{E}-\mathrm{FU}$

$\mathrm{E}-\mathrm{FI}$

$\mathrm{E}-\mathrm{FI}$

$\mathrm{E}-\mathrm{FU}$

$\mathrm{E}-\mathrm{FI}$

$\mathrm{E}-\mathrm{FA}$

E-FA

$\mathrm{E}-\mathrm{FA}$

$\mathrm{E}-\mathrm{FA}$

$\mathrm{E}-\mathrm{FA}$

$\mathrm{E}-\mathrm{FA}$

$\mathrm{E}-\mathrm{FA}$

E-FA

E-FI

$\mathrm{E}-\mathrm{FU}$

$\mathrm{E}-\mathrm{FI}$

-FI

E-FU

-FA

$E-F A$

$\mathrm{E}-\mathrm{FI}$

P-FI
$F$. verrucosa Warburg

$F$. vieillardii Martelli

$\mathrm{E} \rightarrow \mathrm{FA}$

Pandanus

$P$. altissimus Solms

$P$. aragoensis Solms

$P$. balansae Solms

$P$. bernardii St. John

$P$. clandestinus B. C. Stone

P. lacuum St. John

P. mackeei St. John

$P$. macrocarpus

(Brongniart) Solms

$P$. neocaledonicus Martelli

$\mathrm{E}-\mathrm{FA}$

P. spaerocephalus

(Brongniart) Solms

$P$. verecundus B. C. Stone

$P$. vieillardii Martelli

$E-F I$

$\mathrm{E}-\mathrm{FA}$

$\mathrm{E}-\mathrm{FU}$

E-FI

$\mathrm{E}-\mathrm{FA}$

$\mathrm{E}-\mathrm{FU}$

$\mathrm{E}-\mathrm{FU}$

$\mathrm{E}-\mathrm{FA}$

$\mathrm{E}-\mathrm{FI}$

$\mathrm{E}-\mathrm{FI}$

$\mathrm{E}-\mathrm{FU}$

PAPILIONACEAE

Arthroclianthus

$A$. andersonii

(Seemann) Schindler

A. angustifolius

Hochreutiner

A. balansae Schindler

A. caudatus Schindler

A. comptonii E. G. Baker

$A$. cuneatus Schindler

A. grandifolius E. G. Baker

A. ischnopodus Guillaumin

A. leratii Schindler

A. macrobotryosus

Hochreutiner

A. macrophyllus Schindler

A. maximus Schindler

A. microbotrys

Hochreutiner

A. ovalifolius Schindler

$A$. tenuifolius Schindler

A. vieillardii Schindler

Mucuna

$M$. gigantea (Willdenow) A. DC.

$M$. neocaledonica E. G. Baker

$M$. urens Medic.

PARACRYPHIACEAE

Paracryphia

$P$. alticola

(Schlechter) Steenis

PASSIFLORACEAE

Passiflora

P. aurantia J. R. Forster

$\mathrm{E}-$

E-FA

$\mathrm{E}-\mathrm{MI}$

$E-\overline{E A}$

$\mathrm{E}-\mathrm{FU}$

E-FA

$\mathrm{E}-\mathrm{FA}$

$\mathrm{E}-\mathrm{FA}$

$\mathrm{E}-$ -

$\mathrm{E}-\mathrm{FA}$

$\mathrm{E}-\mathrm{E}$

E- -

$\mathrm{P}-\overline{\mathrm{FA}}$

$\mathrm{E}-\mathrm{FA}$
$\mathrm{P}-\mathrm{FA}$

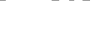

PA

$E-F I$

$\mathrm{P}-\mathrm{MI}$

PHELLINACEAE

Phelline

P. balansae Baillon

P. billardieri

Pancher ex Loesener

$P$. brachyphylla Baillon

$P$. comosa Labillardière

$P$. confertifolia Baillon

$P$. dumbeensis Guillaumin

$P$. erubescens Baillon

$P$. floribunda Baillon

$P$. indivisa

(Baillon) Harms \& Loesener

$P$. lucida Vieillard ex Baillon

$P$. macrophylla Baillon

$P$. microcarpa Baillon

$P$. robusta Baillon

$P$. wagapensis Baillon

PHILESIACEAE

Eustrephus

$E$. latifolius $\mathrm{R}$. Brown ex Sims $\quad \mathrm{P}-\mathrm{FI}$
E-D

$\mathrm{E}-\mathrm{FU}$

E-FA

E-FI

E-FA

$\mathrm{E}-\mathrm{FU}$

E-MI

$\mathrm{E}-\overline{\mathrm{FU}}$

$\mathrm{E}-\mathrm{FI}$

$\mathrm{E}-\mathrm{FU}$

$\mathrm{E}-\mathrm{FU}$

$\mathrm{E}-\mathrm{FA}$ 


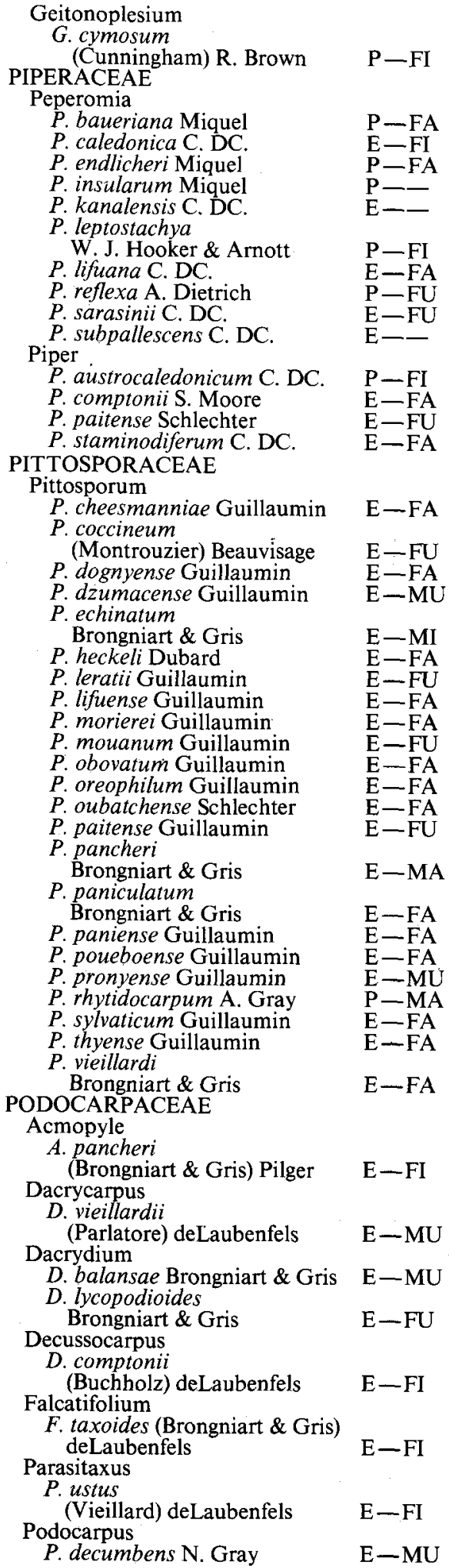

$P$. longefoliolatus Pilger

$P$. lucienii deLaubenfels

$P$. polyspermus deLaubenfels

$P$. sylvestris Buchholz

Prumnopitys

$P$. ferruginoides

(Compton) deLaubenfels E-FI

PROTEACEAE

Beauprea

B. asplenioides Schlechte

B. comptonii $\mathrm{S}$. Moore

$B$. crassifolia Virot

$B$. filipes Schlechter

B. gracilis Brongniart \& Gris

B. montana

(Brongniart \& Gris) Virot

$B$. montisfontium Guillaumin

B. neglecta Virot

B. pancheri Brongniart \& Gris

$B$. spathulaefolia

Brongniart \& Gris

Kermadecia

$K$. elliptica Brongniart \& Gris

$K$. pronyensis

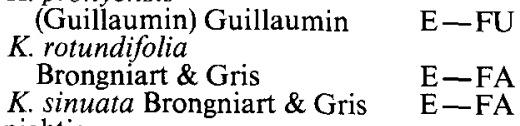

Knightia

$K$. deplanchei Vieillard ex

Brongniart \& Gris

$\mathrm{E}-\mathrm{FU}$
$\mathrm{E}-\mathrm{FI}$
$\mathrm{E}-\mathrm{FI}$
$\mathrm{E}-\mathrm{FI}$

$\mathrm{E}-\mathrm{FU}$

$\mathrm{E}-\mathrm{FA}$

$\mathrm{E}-\mathrm{MA}$

$\mathrm{E}-\mathrm{MU}$

E-MU

E-MU

$E-M U$

$\mathrm{E}-\mathrm{MU}$

E-MU

E-FA

$K$. strobilina

(Labillardière) R. Brown

$\mathrm{E}-\mathrm{MU}$

$\mathrm{E}-\mathrm{FI}$

Macadamia

$M$. francii (Guillaumin) Sleumer E-FI

$M$. neurophylla

(Guillaumin) Virot $\quad E-F U$

$M$. rousselii

(Vieillard) Sleumer $\quad$ E-FA

$M$. vieillardii

(Brongniart \& Gris) Sleumer E-FA

Sleumerodendron

S. austrocaledonicum

(Brongniart \& Gris) Virot E-FI

Stenocarpus

$S$. intermedius

Brongniart \& Gris

$S$. rubiginosus

Brongniart \& Gris

$S$. trinervis

(Montrouzier) Guillaumin

S. umbelliferus

(Forster) Druce

Virotia

$V$. leptophylla (Guillaumin)

L. Johnson \& Briggs $\quad E-F$

RHAMNACEAE

Alphitonia

A. neocaledonica Guillaumin E-MI

A. xerocarpa Baillon $\quad \mathrm{E}-\mathrm{FU}$

Ventilago

$V$. buxoides Baillon

RHIZOPHORACEAE

Crossostylis

C. biflora J. R. \& G. Forster P-Fl

C. grandiflora

Pancher ex Brongniart \& Gris E-FA

C. multiflora

Brongniart \& Gris

$C$. seberti Brongniart \& Gris

RUBIACEAE

Atractocarpus

$A$. aragoensis Guillaumin

$E-F A$ 


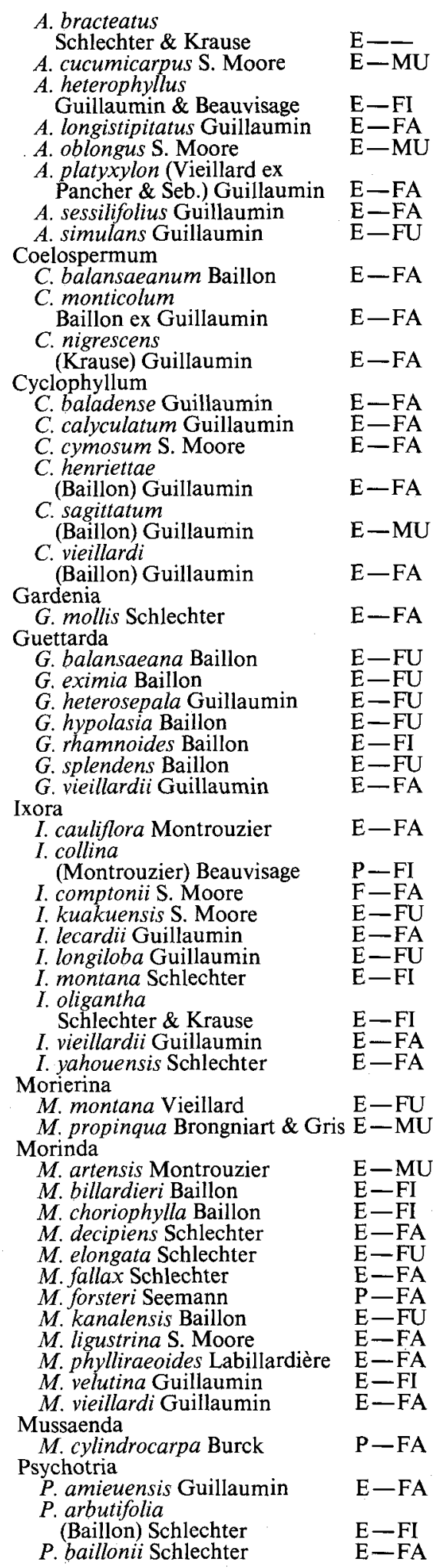

P. baladensis

(Baillon) Guillaumin $\quad$ E-FA

$P$. bourailensis Guillaumin

P. brachylaena

(Baillon) Guillaumin E-FA

$P$. calliantha

(Baillon) Guillaumin $\quad \mathrm{E}-\mathrm{FI}$

$P$. calothyrsus

(Baillon) Guillaumin $\quad \mathrm{E}-\mathrm{FI}$

$P$. canalensis

(Baillon) Guillaumin $\quad \mathrm{E}-\mathrm{FA}$

$P$. collina Labillardière $\quad \mathrm{P}-\mathrm{FI}$

$P$. colnettiana Guillaumin $\quad$ E-FA

$P$. damnatorum Guillaumin $\quad \mathrm{E}-\mathrm{FA}$

$P$. deplanchei

(Beauvisage) Guillaumin $\mathrm{E}-\mathrm{FU}$

$P$. douarrei
(Beauvisage) Daeniker $\quad \mathrm{E}-\mathrm{FU}$

P. faguetii

(Baillon) Schlechter

$P$. frondosa S. Moore

P. fuscopilosa Schlechter

$P$. gabriellae

(Baillon) Guillaumin

$P$. gneissica S. Moore

$P$. goniocarpa

(Baillon) Guillaumin

P. laxissima S. Moore

$P$. lenormandi Schlechter

P. lepidocalyx S. Moore

$P$. leratii Guillaumin

$P$. ligustrina

(Baillon) Guillaumin

P. lyciiflora

(Baillon) Schlechter

P. lycioides

(Baillon) Guillaumin

P. macroglossa

(Baillon) Guillaumin $\quad \mathrm{E}-\mathrm{FI}$

P. microglossa

(Baillon) Guillaumin $\quad \mathrm{E}-\mathrm{FI}$

P. monanthos

(Baillon) Schlechter E-FU

$P$. nathaliae

(Baillon) Guillaumin $\quad \mathrm{E}-\mathrm{MU}$

$P$. nekouana

(Baillon) Guillaumin

$P$. nummularioides Guillaumin $\mathrm{E}-\overline{\mathrm{FA}}$

$P$. oleoides (Baillon) Schlechter E-MU

$P$. oreophila Guillaumin E-FA

$P$. oubatchensis Schlechter E-FA

$P$. pancheri

(Baillon) Schlechter $\quad E-F A$

$P$. papillosa Guillaumin $\quad$ E-FA

$P$. paramaracarpa

(Baillon) Schlechter E-MU

$P$. patula S. Moore E-FA

$P$. phyllanthoides

Schlechter ex Guillaumin $\quad \mathrm{E}-\mathrm{MU}$

$P$. poissoniana

(Baillon) Guillaumin $\quad \mathrm{E}-\mathrm{FI}$

$P$. pseudomicrodaphne

(Baillon) Guillaumin $\quad \mathrm{E}-\mathrm{MU}$

P. pubituba S. Moore E-FA

$P$. pulchrebracteata Guillaumin E-FA

$P$. rarifolia S. Moore $\mathrm{E}-\mathrm{FA}$

$P$. roseotincta S. Moore $\quad \mathrm{E}-\mathrm{FA}$

$P$. rosmarinifolia

(Baillon) Schlechter E-FA

$P$. rubefacta

(S. Moore) Guillaumin E-MU

P. rupicola

(Baillon) Schlechter $\quad$ E-MI 
P. sagittalis (Baillon) Guillaumin

$P$. saltiensis

(S. Moore) Guillaumin

$P$. schlechteriana Krause

$P$. schumanniana Schlechter

$P$. semperflorens (Baillon)

Pancher ex Beauvisage

$P$. speciosa (Beauvisage) S. Moore

P. stenophylla Guillaumin

$P$. stricta (Baillon) Guillaumin

$P$. suaveolens $\mathrm{S}$. Moore

$P$. subpallens $\mathrm{S}$. Moore

$P$. subuniflora

(Baillon) Schlechter

$P$. toninensis S. Moore

$P$. trichopodantha (Baillon) Guillaumin

$P$. trisulcata (Baillon) Guillaumin

-P. unioensis Guillaumin

$P$. vieillardii (Baillon) Baillon

$P$. wagapensis Guillaumin

Randia

$R$. artensis

(Montrouzier) Guillaumin

$R$. sezitat Guillaumin

$R$. vieillardii Baillon

Rhopalobrachium

$R$. congestum

Schlechter \& Krause $\quad$ E-FA

$R$. fragrans

Schlechter \& Krause E-FA

Tarenna

T. ignambiensis

(Guillaumin) Jérémie

$T$. lifouana (Daeniker) Jérémie

T. truncatocalyx

(Guillaumin) Bremekamp

T. unioensis

(Guillaumin) Jérémie

$E-F A$

$\mathrm{E}-\mathrm{FU}$

E-FA

E-FA

$\mathrm{E}-\mathrm{FI}$

$\mathrm{E}-\mathrm{MU}$

$\mathrm{E}-\overline{\mathrm{FA}}$

$\mathrm{E}-\mathrm{FA}$

E-MU

$\mathrm{E}-\mathrm{FU}$

$\mathrm{E}-\mathrm{FA}$

E-FA

$\mathrm{E}-\mathrm{FA}$

$\mathrm{E}-\mathrm{FI}$

E-FA

$\mathrm{E}-\mathrm{FA}$

E-FA

E-FA

$\mathrm{E}-\mathrm{FA}$

E-FA

$\mathrm{E}-\mathrm{FA}$

E-MI

E-FA

RUTACEAE

Dutaillyea

D. comptonii E. G. Baker

$D$. oreophylla Guillaumin

D. sessilifoliola Guillaumin

D. trifoliolata Baillon

$$
\begin{aligned}
& E-F A \\
& E-F I \\
& E-M I \\
& E-F A
\end{aligned}
$$

Geijera

$\widetilde{G}$. balansae (Baillon) Schinz \& Guillaumin

$\mathrm{E}-\mathrm{FI}$

Melicope

$M$. diversifolia Guillaumin

$M$. glaberrima Guillaumin

$M$. lasioneura Baillon

$M$. leptophylla Guillaumin

$M$. leratii Guillaumin

$M$. montana E. G. Baker

$M$. platystemon E. G. Baker

M. triphylla Merrill

$\mathrm{E}-\mathrm{FA}$

$E-F I$

$\mathrm{E}-\mathrm{FU}$

$\mathrm{E}-\overline{\mathrm{FU}}$

$\mathrm{E}-\mathrm{FA}$

$\mathrm{E}-\mathrm{FA}$

$\mathrm{E}-\mathrm{FI}$

Micromelum

M. minutum (J. R. \&

G. Forster) Wight \& Arnott P-FA

Sarcomelicope

S. argyrophylla Guillaumin $\quad$ E-FI

$S$. sarcococca Engler

$\mathrm{E}-\mathrm{FI}$

Zanthoxylum

Z. neocaledonicum E. G. Baker E-FU

$Z$. pinnatum

(J. R. \& G. Forster) Oliver

Z. sarasinii Guillaumin

$\mathrm{P}-\mathrm{MI}$

E-MA

Z. schlechteri Guillaumin
$\mathrm{E}-\mathrm{FI}$
Zieridium

$$
\begin{array}{ll}
\text { Z. melicopaefolium Guillaumin } & \mathrm{E}-\mathrm{FI} \\
\begin{array}{ll}
\text { pseudobtusifolium } \\
\text { Guillaumin }
\end{array} & \mathrm{E}-\mathrm{FI}
\end{array}
$$

SANTALACEAE

Amphorogyne

A. celastroides

Stauffer \& Huerlimann E-FI

A. spicata

Stauffer \& Huerlimann $\quad$ E-FI

Daenikera

D. corallina

Huerlimann \& Stauffer $\quad$ E-FU

Exocarpos

E. phyllanthoides Endlicher $\quad \mathrm{P}-\mathrm{MU}$

E. pseudocasuarina Guillaumin E-MU

Santalum

S. austrocaledonicum Vieillard E-MI

\section{SAPINDACEAE}

Alectryon

A. carinatum Radlkofer

$\mathrm{E}-\mathrm{FA}$

Arytera

A. arcuata Radlkofer

A. gracilipes Radlkofer

A. lepidota Radlkofer

E-MA

Cupaniopsis

C. apiocarpa Radlkofer

C. azantha Radlkofer

C. chytradenia Radlkofer

C. dictyophora Radlkofer

C. ganophloea Radlkofer

C. godefroyi Guillaumin

C. guioides Guillaumin

C. hypodermatica Radlkofer

C. macrocarpa Radlkofer

C. mareensis Guillaumin

C. mouana Guillaumin

C. oedipoda Radlkofer

C. pennelii Guillaumin

C. petiolutata Radlkofer

C. psilocarpa Radlkofer

C. subcuneata Radlkofer

C. sylvatica Guillaumin

C. trigonocarpa Radlkofer

E-MU

$\mathrm{E}-\mathrm{MU}$

$\mathrm{E}-\mathrm{MI}$

$\mathrm{E}-\mathrm{FA}$

$\mathrm{E}-\mathrm{MU}$

E-FA

$\mathrm{E}-\mathrm{FA}$

$\mathrm{E}-\longrightarrow$

$\mathrm{E}-\longrightarrow$

E-MI

E-FA

$\mathrm{E}-\mathrm{FU}$

E-FI

E-FA

E-FA

$\mathrm{E}-\mathrm{FA}$

E-MI

E-FU

Elattostachys

E. apetala

(Labillardière) Radlkofer E-FI

E. falcato

(A. Gray) Radlkofer

E. incisa Radlkofer

$\mathrm{P}-\overline{\mathrm{EA}}$

Gongrodiscus

$G$. sp.

G. subferrugineus Radlkofer

E-FA

Guioa

G. crenata Radlkofer

$G$. crenulata Radlkofer

G. fusca Radlkofer

G. glauca

(Labillardière) Radlkofer

$G$. gracilis

(Pancher \& Sebert) Radlkofer E-MI

$G$. microsepala Radlkofer

$G$. pectinata Radlkofer

$G$. villosa Radlkofer

$\mathrm{E}-\mathrm{FI}$

arpullia

H. austrocaledonica Baillon

E-MI

Podonephelium

$P$. balansae Guillaumin

$P$. concolor Radlkofer

$P$. homei (Seemann) Radlkofer

E-FA

E-MI

$\mathrm{E}-\mathrm{MI}$

$\mathrm{E}-\mathrm{MI}$

Storthocalyx

S. chryseus Radlkofer

$\mathrm{E}-\mathrm{FA}$

$\mathrm{E}-\mathrm{MU}$

$\mathrm{E}-\mathrm{FI}$

$\mathrm{E}-\mathrm{FI}$ 


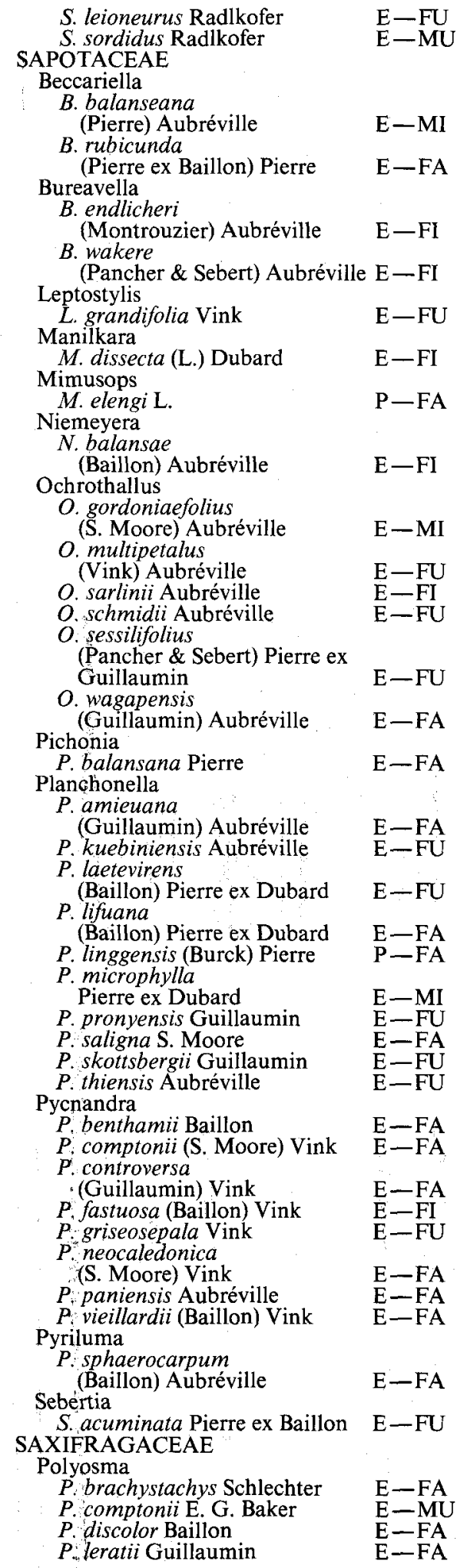

$P$. pancheri Baillon

$P$. podophylla Schlechter

$P$. spicata Baillon

Quintinia

Q. major (Baillon) Schlechter $\quad$ E-FI

$Q$. media (Baillon) Guillaumin

Q. minor (Baillon) Schlechter

$Q$. oreophila

(Schlechter) Schlechter

$Q$. parviflora

(Schlechter) Schlechter

SIMAROUBACEAE

Soulamea

S. fraxinifolia

Brongniart \& Gris

S. muelleri Brongniart \& Gris

SMILACACEAE

Smilax

S. orbiculata Labillardière

S. plurifurcata A. DC

SOLANACEAE

Duboisia

D. myoporoides $\mathrm{R}$. Brown

SPHENOSTEMONACEAE

Sphenostemon

S. balansae Baillon

S. comptonii E. G. Baker

S. oppositifolius

Huerlimann

S. pachycladum Baillon

STERCULIACEAE

Sterculia

$S$. austrocaledonica

J. D. Hooker

S. bullata Pancher \& Sebert

S. comptonii E. G. Baker

$S$. dzumacensis Guillaumin

S. fatsioides

(Schlechter) Guillaumin

$S$. francii Guillaumin

S. megaphylla Bureau \&

Poisson ex Guillaumin

$S$. platanoides Schlechter

S. sageniifolia

(Schlechter) Guillaumin

$S$. scheffleraefolia Guillaumin

S. schumanniana

(Schlechter) Guillaumin

$\mathrm{E}-\mathrm{FU}$

E-FA

E-FA

$\mathrm{E}-\mathrm{MU}$

$E-F U$

$\mathrm{E}-\mathrm{FA}$

E-FI

$\mathrm{E}-\mathrm{MU}$

$\mathrm{E}-\overline{\mathrm{MI}}$

$\mathrm{P}-\mathrm{MI}$

$\mathrm{E}-\mathrm{MU}$

$\mathrm{E}-\mathrm{MI}$

$\mathrm{E}-\mathrm{FU}$

$\mathrm{E}-\mathrm{FI}$

$\mathrm{E}-\mathrm{FI}$

P-MA

E-FI

E-FU

E-FA

$\mathrm{E}-\mathrm{MU}$

$\mathrm{E}-\mathrm{FA}$

$\mathrm{E}-\mathrm{MU}$

$E-F A$

$\mathrm{E}-\mathrm{FI}$

$\mathrm{E}-\mathrm{FA}$

STRASBURGERIACEAE

Strasburgeria

S. robusta (Vieillard ex Pancher

\& Sebert) Guillaumin

$\mathrm{E}-\mathrm{FU}$

SYMPLOCACEAE

Symplocos

S. arborea

(Vieillard) Brongniart \& Gris E-FA

$S$. baptica Brongniart \& Gris $\quad \mathrm{E}-\mathrm{FI}$

S. caerulescens

Brongniart \& Gris

$S$. flavescens Brand

S. gracilis Brongniart \& Gris

$S$. montana Brongniart \& Gris

S. munda S. Moore

$S$ pseudonitida Guillaumin $\quad \mathrm{E}-\mathrm{FA}$

TAXACEAE

Austrotaxus

A. spicata Compton

$\mathrm{E}-\mathrm{FA}$

$\mathrm{E}-\mathrm{FI}$

$\mathrm{E}-\mathrm{FA}$

$\mathrm{E}-\mathrm{MI}$

E-FI

THYMELEACEAE

Lethedon

L. balansae

(Baillon) Kostermans $\quad$ E-MI 
L. calleana

(Guillaumin) Kostermans

L. cernua (Baillon) Kostermans

L. ciliaris (Baillon) Kostermans

L. comptonii

(E. G. Baker) Kostermans

L. cordatoretusa Aymonin

L. oblonga

(Schlechter) Kostermans

L. ovata

(Guillaumin) Kostermans

L. salicifolia

(Labillardière) Aymonin

Microsemma

M. calophylla

Guillaumin \& MacKee

$M$. rhizophoraefolia

Guillaumin

Wickstroemia

$W$. indica (L.) Mey
$W$. novaecaledonica Gandoger

TILIACEAE

Trichospermum

$T . \mathrm{sp}$.

TRIMENIACEAE

Trimenia

T. neocaledonica E. G. Baker

TRIURIDACEAE

Sciaphila

S. dolichostyla Schlechter

$S$. neocaledonica Schlechter

ULMACEAE

Celtis

C. balansae Planchon
C. paniculata

(Endlicher) Planchon

URTICACEAE

Dendrocnide

D. latifolia (Gandoger) Chew

D. vitiensis (Seemann) Chew

Procris

$P$. pedunculata

(J. R. Forster) Weddell P-FI

\section{VERBENACEAE}

Gmelina

G. lignum-vitreum Guillaumin

Oxera
$O$. arborea Schlechter
$O$. baladica Vieillard
$O$. candelabrum Beauvisage
$O$. comptonii $\mathrm{S}$. Moore
$O$. cordifolia Dubard
$O$. coriacea Dubard
$O$. crassiflora S. Moore
$O$. crassifolia Virot
O. floribunda Schlechter
$O$. longifolia Vieillard
$O$. merytaefolia Guillaumin
O. microcalyx Guillaumin
$O$. morierii Vieillard
O. nuda Virot
$O$. oblongifolia Vieillard
$O$. oreophila Guillaumin
$O$. ovata Vieillard
$O$. palmatinervia Dubard
$O$. pancheri Dubard
$O$. robusta Vieillard
O. rugosa Guillaumin
$O$. suaveolens Guillaumin
O. subverticillata Vieillard
O. sulfurea Dubard

$\mathrm{E}-\mathrm{FU}$

$\mathrm{E}-\mathrm{FU}$

E-FA

$\mathrm{E}-\mathrm{MI}$

$\mathrm{E}-\mathrm{MU}$

$\mathrm{E}-\mathrm{MU}$

$\mathrm{E}-\mathrm{MI}$

$\mathrm{E}-\mathrm{FU}$

$\mathrm{E}-\mathrm{FA}$

P-MI

$\mathrm{E}-\mathrm{P}$

P-FA

$\mathrm{E}-\mathrm{FA}$

E-FA

$\mathrm{E}-\mathrm{FU}$

$E-F A$

$\mathrm{P}-\mathrm{FA}$

$\mathrm{P}-\mathrm{FA}$

$\mathrm{P}-\mathrm{FA}$

E-FA

E-FA

E-FA

$\mathrm{E}-\mathrm{FI}$

$\mathrm{E}-\mathrm{FA}$

$\mathrm{E}-$

$\mathrm{E}-\mathrm{MU}$

$E-F A$

$\mathrm{E}-\overline{\mathrm{FA}}$

E-FA

E-FA

$\mathrm{E}-\mathrm{MI}$

$\mathrm{E}-\overline{\mathrm{FU}}$

$\mathrm{E}-\mathrm{FU}$

$\mathrm{E}-\mathrm{FU}$

$\mathrm{E}-\overline{\mathrm{FI}}$

$\mathrm{E}-\mathrm{FU}$

$\mathrm{E}-\mathrm{MU}$

$E-\overline{F A}$
$\mathrm{E}-\mathrm{FA}$
Vitex

$V$. neocaledonica Gandoger

$V$. rapini Beauvisage

$\mathrm{E}-\overline{\mathrm{FU}}$

VIOLACEAE

Agatea

A. lenormandi Melchior

A. schlechteri Melchior

Hybanthus

H. austrocaledonicus

Schinz \& Guillaumin

H. caledonicus (Turcz) Cretz

$H$. ilicifolius (Vieillard) Schinz \& Guillaumin

WINTERACEAE

Belliolum

B. crassifolium

(Baillon) Tieghem

$B$. rivulare Tieghem

$B$. vieillardi Tieghem

Bubbia

$B$. auriculata Tieghem

$B$. balansae (Baillon) Tieghem

B. comptonii (Baker f.) Dandy

$B$. deplanchei Tieghem

$B$. heteroneura Tieghem

$B$. isoneura Tieghem

$B$. odorata (Baker f.) Dandy

$B$. pauciflora (Baker f.) Dandy

Exospermum

E. stipitatum (Baillon) Tieghem

$\mathrm{E}-\overline{\mathrm{EI}}$

$\mathrm{E}-\mathrm{FU}$

$\mathrm{P}$-MI

$E-F I$
$E-F A$

Zygogynum

Z. acsmithii Vink

Z. baillonii Tieghem

$Z$. bicolor Tieghem

Z. mackeei Vink

$Z$. pomiferum Baillon

$Z$. vieillardii Baillon

$\mathrm{E}-\mathrm{FA}$

$\mathrm{E}-\mathrm{FA}$

E-FA

E-FA

E-FU

E-FA

$E-F A$

$\mathrm{E}-\mathrm{FA}$

E-FA

$\mathrm{E}-\mathrm{FA}$

$E-F A$

$E-F A$

$\mathrm{E}-\mathrm{FU}$

$\mathrm{E}-\mathrm{FU}$

$E-F A$

E-FA

$\mathrm{E}-\mathrm{FU}$

$\mathrm{E}-\mathrm{FU}$ 


\section{APPENDIX 2}

\section{Rainforest genera and their phytogeographic distribution}

\section{Symbols used}

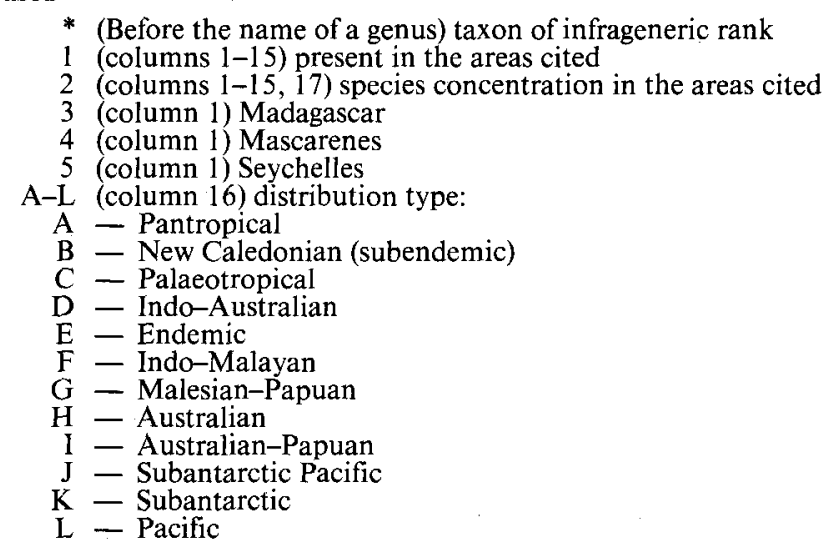

ACAN. Graptophyllum

ACAN. Hemigraphis

ACAN. Justicia

ACAN. Pseuderanthemum

AGAV. Cordyline

ALAN. Alangium

ALSE. Periomphale

AMAR. Campynema

AMAR. Campynemanthe

AMBO. Amborella

AMPE. Cayratia

AMPE. Cissus

ANAC. Euroschinus

ANAC. Semecarpus

ANON. Desmos

ANON. Polyalthia

ANON. Richella

ANON. Uvaria

ANON. Xylopia

APOC. Alstonia

APOC. Alyxia

APOC. Artia

APOC. Cerbera

APOC. Cerberiopsis

APOC. Melodinus

APOC. Neisosperma

APOC. Ochrosia

APOC. Pagiantha

APOC. Parsonsia

APOC. Rauvolfia

AQUI. Ilex

ARAC. Epipremnum (Rhaphidophora)

ARAL. Apiopetalum

ARAL. Arthrophyllum

ARAL. Botryomeryta

ARAL. Delarbrea

ARAL. Dizygotheca

ARAL. Meryta

ARAL. Myodocarpus

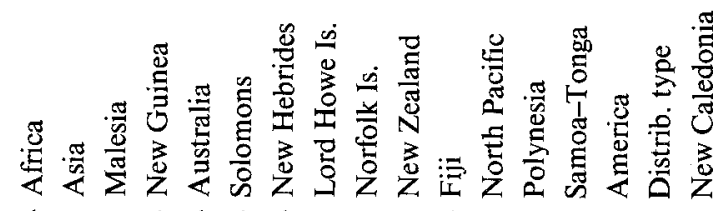

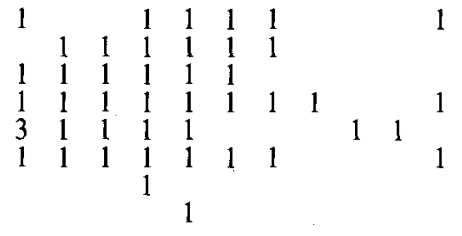
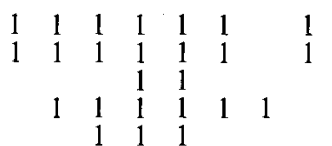

$\begin{array}{llllllll}4 & 1 & 2 & 1 & 1 & 1 & 1\end{array}$

$\begin{array}{lllllll}1 & 1 & 1 & 1 & 1 & 1\end{array}$

$\begin{array}{lllllll}1 & 1 & 1 & 1 & & 1 & 1 \\ 1 & & 1 & 1 & 1 & 1 & 1\end{array}$

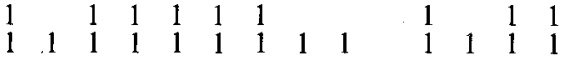

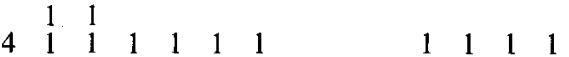

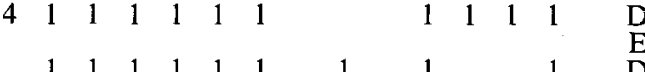

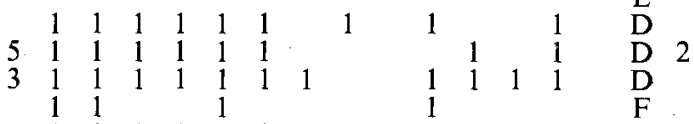

$\begin{array}{llllllllllllll}1 & 1 & 1 & 1 & 1 & 1 & 1 & 1 & 1 & 1 & & \text { D } \\ 1 & 1 & 1 & 1 & 1 & 1 & & & & & & 1 & 1 & A\end{array}$

$\begin{array}{llllllllllllllll}1 & 1 & 1 & 1 & 1 & & 1 & 1 & & 1 & & 1 & 1 & A \\ 1 & 1 & 2 & 1 & 1 & 1 & 1 & & & 1 & 1 & 1 & 1 & & A\end{array}$

11

$\begin{array}{lll}\mathrm{E} & \end{array}$

E

$\begin{array}{lllll}1 & 1 & 1 & 1 & 1\end{array}$

B 2

$\begin{array}{ll}\mathrm{B} & 2 \\ \mathrm{~B} & 2\end{array}$

111 
ARAL. Polyscias (Tieghemopanax)

ARAL. Schefflera

ARAL. Strobilopanax

ARAU. Agathis

ARAU. Araucaria

ASCL. Hoya

ASCL. Marsdenia

ASCL. Secamone

ASCL. Tylophora

ATHE. Nemuaron

BALA. Balanophora

BALA. Hachettea

BALO. Balanops

BIGN. Deplanchea

BIGN. Pandorea

BISC. Bischofia

* BURS. Canarium (Sect. Canariellum)

CASU. Gymnostoma (Casuarina)

CELA. Cassine (Elaeodendron)

CELA. Maytenus

CELA. Menepetalum

CELA. Salaciopsis

CESA. Caesalpinia

CESA. Intsia

CESA. Mezoneurum

CESA. Storckiella

CHLO. Ascarina

CHRY. Hunga

COMM. Aneilema

CONN. Rourea (Santaloides)

CORY. Corynocarpus

CUCU. Diplocyclos

CUNO. Acsmithia

CUNO. Codia

CUNO. Cunonia

CUNO. Geissois

CUNO. Pancheria

CUNO. Weinmannia

CUPR. Libocedrus

CYPE. Baumea

CYPE. Carex

CYPE. Costularia

CYPE. Scleria

CYPE. Uncinia

DILL. Hibbertia

DILL. Tetracera

DIOS. Dioscorea

EBEN. Diospyros

ELAE. Dubouzetia

ELAE. Elaeocarpus

* ELAE. Sloanea (s.g. Antholoma)

EPAC. Dracophyllum

EPAC. Styphelia

ERIC. Agapetes

ESCA. Argophyllum

EUPH. Antidesma

EUPH. Austrobuxus

EUPH. Baloghia

EUPH. Bocquillonia

EUPH. Claoxylon

EUPH. Cleidion

EUPH. Cleistanthus

EUPH. Cocconerion

EUPH. Codiaeum

EUPH. Croton

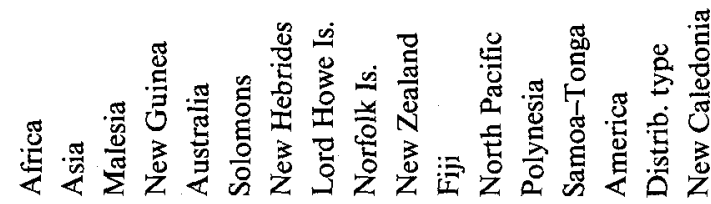

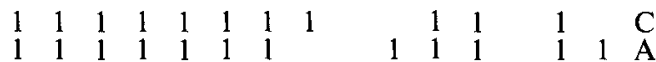

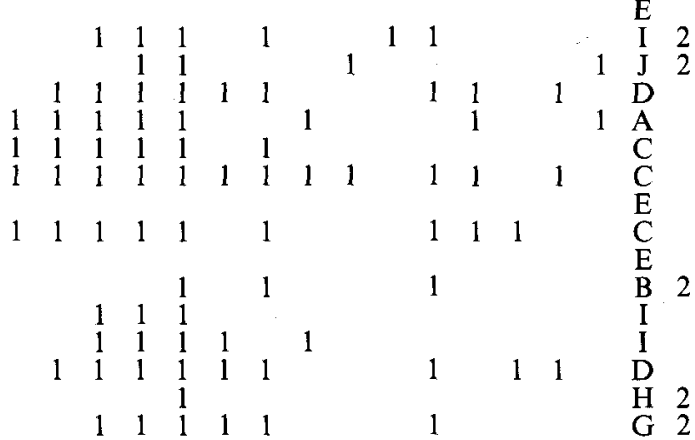

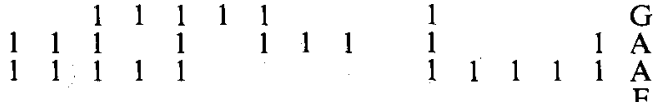

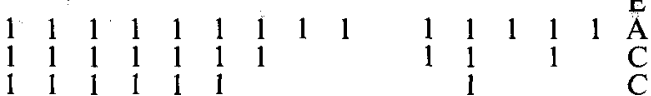

$\begin{array}{lllllllllllllll} & 4 & 1 & 1 & & 1 & 1 & & 1 & 1 & & 1 & 1 & & \text { L }\end{array}$

$\begin{array}{lllllllllll}1 & 1 & 1 & 1 & 1 & 1 & 1 & 1 & 1 & \text { A } & 2\end{array}$

$\begin{array}{llllllllll}1 & 1 & 1 & 1 & 1 & 1 & 1 & 1 & 1 & A\end{array}$

$\begin{array}{llllllllllll}1 & 1 & 1 & 1 & 1 & 1 & 1 & 1 & & & \text { I } \\ & & 1 & 1 & 1 & & & & & 1 & \text { C } & \\ 1 & & & & & & & & & & \end{array}$

$1 \quad 1,1, \quad \underset{K}{\mathrm{E}} \underset{2}{\mathrm{H}}$

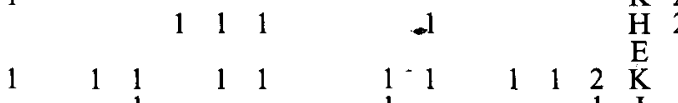

$\begin{array}{llllllll}1 & 1 & 1 & 1 & 1 & 1 & & \end{array}$

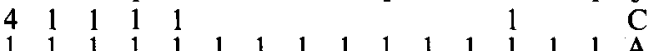

$\begin{array}{llllllllllllllll}1 & 1 & 1 & 1 & 1 & 1 & 1 & 1 & 1 & 1 & 1 & 1 & 1 & 1 & 1 & \mathrm{~A} \\ 1 & & 1 & 1 & 1 & & & & & & & & & & & \\ \mathrm{C}\end{array}$

$\begin{array}{llllllllllll}1 & 1 & 1 & 1 & 1 & 1 & 1 & 1 & 1 & 1 & 1 & A\end{array}$

$\begin{array}{lllllllllllll}1 & 1 & 1 & 1 & 1 & 1 & 1 & & 1 & & & & \end{array}$

$\begin{array}{llllllllll}1 & 1 & 1 & 1 & 1 & 1 & \mathrm{~A}\end{array}$

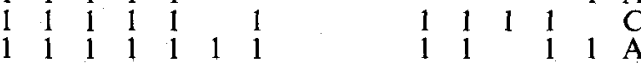

$\begin{array}{lllllllllllllllllllllll}1 & 1 & 1 & 1 & 1 & 1 & 1 & 1 & & 1 & 1 & 1 & 1 & 1 & & \mathrm{C}\end{array}$

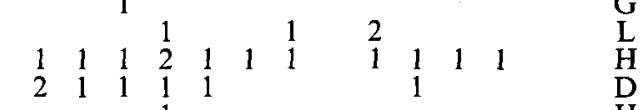

$\begin{array}{lllllllllllll}1 & 1 & 2 & 1 & 1 & 1 & 1 & & 1 & 1 & 1 & \mathrm{H} & 2 \\ & & 1 & 1 & 1 & & & & 1 & & & \text { H } & 2 \\ & & & & 1 & & & 1 & & & & \text { B } & 2\end{array}$

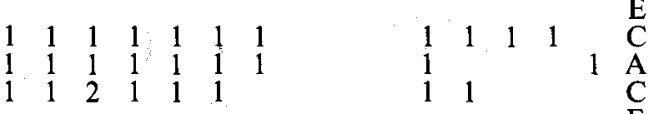

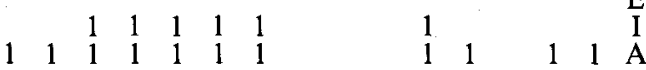


EUPH. Dendrophyllanthus

EUPH. Drypetes

EUPH. Glochidion

EUPH. Homalanthus

EUPH. Macaranga

EUPH. Mallotus

EUPH. Neoguillauminia

EUPH. Phyllanthus

FAGA. Nothofagus

FLAC. Casearia

FLAC. Homalium

FLAC. Lasiochlamys

FLAC. Xylosma

FLAG. Flagellaria

FLIN. Flindersia

GESN. Coronanthera

GESN. Depanthus

* GOOD. Scaevola (Sect. Scaevola)

GRAM. Centosteca

GRAM. Leptaspis

GRAM. Oplismenus

GUTT. Calophyllum

GUTT. Garcinia

GUTT. Montrouziera

GUTT. Ochrocarpus

HERN. Hernandia

HIPP. Salacia

ICAC. Apodytes

ICAC. Citronella

ICAC. Gastrolepis

LAUR. Adenodaphne

LAUR. Beilschmiedia

LAUR. Cryptocarya

LAUR. Endiandra

LAUR. Litsea

LECY. Barringtonia

LILI. Arthropodium

LILI. Astelia

LILI. Dianella

LINA. Hugonia

LOGA. Fagraea

LOGA. Geniostoma

LOGA. Neuburgia

LORA. Amyema

LORA. Amylotheca

LORA. Korthalsella

MELI. Aglaia

MELI. Anthocarapa (Amoora)

MELI. Dysoxylum

MENI. Hypserpa

MENI. Pachygone

MENI. Stephania

MIMO. Adenanthera

MIMO. Albizia

MIMO. Serianthes

MONI. Hedycarya

MONI. Kibaropsis

MORA. Ficus

MORA. Sparattosyce

MORA. Streblus

MYRA. Canacomyrica

MYRS. Maesa

MYRS. Rapanea

MYRS. Tapeinosperma

MYRT. Arillastrum
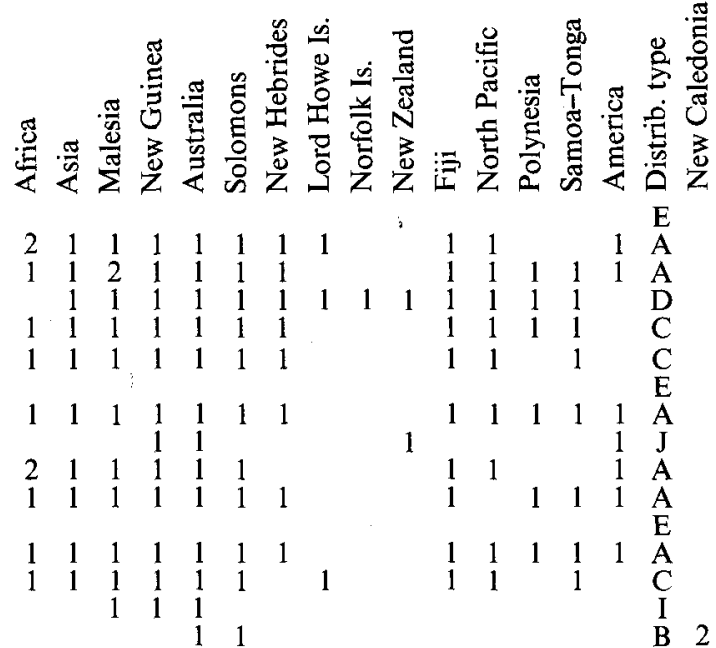

$\mathrm{E}$

A

A

C

A

A

A

2

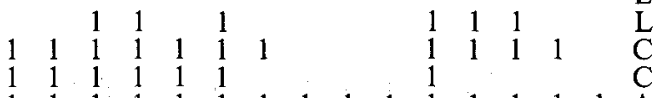

$\begin{array}{llllllllllllllll}1 & 1 & 1 & 1 & 1 & 1 & 1 & 1 & 1 & 1 & 1 & 1 & 1 & 1 & 1 & A\end{array}$

$\begin{array}{llllllllllllllll}1 & 1 & 1 & 1 & 1 & 1 & 1 & 1 & 1 & 1 & 1 & 1 & 1 & 1 & \mathrm{~A} \\ 1 & 1 & 2 & 1 & 1 & 1 & 1 & & & & 1 & 1 & & 1 & & \mathrm{C}\end{array}$

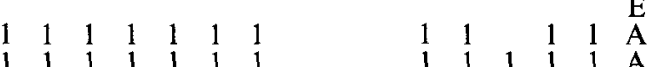

$\begin{array}{lllllllllllll}1 & 1 & 1 & 1 & 1 & 1 & 1 & 1 & 1 & 1 & 1 & 1 & \mathrm{~A} \\ 1 & 1 & 1 & 1 & 1 & 1 & 1 & 1 & 1 & & & 1 & \mathrm{~A}\end{array}$

$\begin{array}{lllllllllll}1 & 1 & 1 & & 1 & & & & & & \\ & & 1 & 1 & 1 & 1 & 1 & 1 & 1 & 1 & \mathrm{~A}\end{array}$

$\begin{array}{lllllllll}1 & 1 & 2 & 1 & 1 & 1 & 1 & 1 & \mathrm{E}\end{array}$

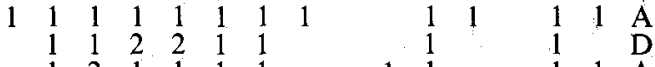

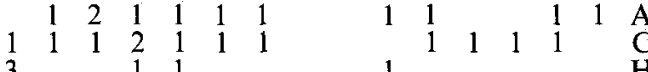

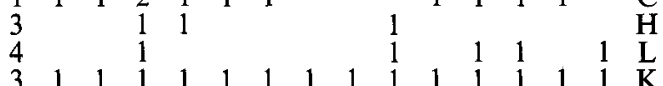

$\begin{array}{lllllllllllllllll}3 & 1 & 1 & 1 & 1 & 1 & 1 & 1 & 1 & 1 & 1 & 1 & 1 & 1 & 1 & \mathrm{~K} & 2 \\ 1 & & 1 & 1 & 1 & 1 & 1 & & & & 1 & & & & & \text { I } & 2\end{array}$

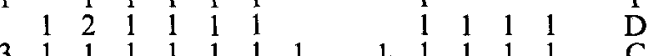

$\begin{array}{lllllllllllllllll}3 & 1 & 1 & 1 & 1 & 1 & 1 & 1 & & 1 & 1 & 1 & 1 & 1 & & C & 2\end{array}$

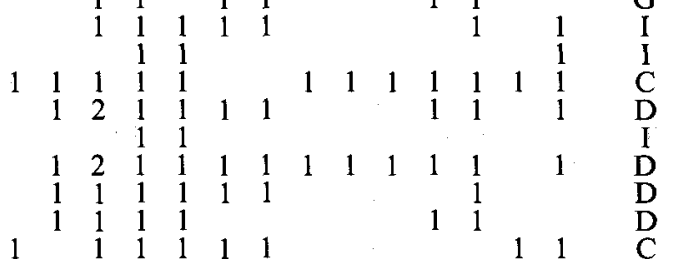

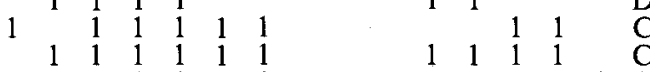

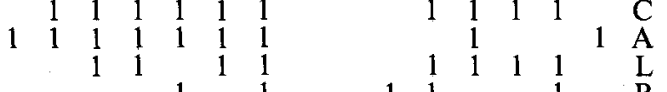

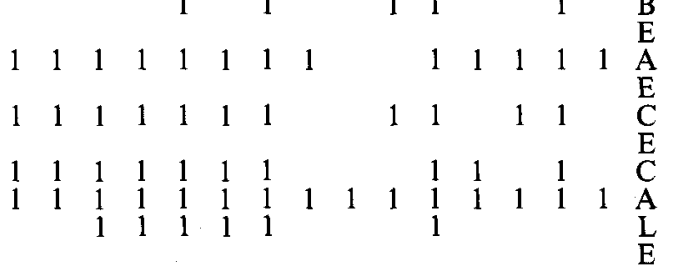


MYRT. Austromyrtus

MYRT. Carpolepis

MYRT. Cleistocalyx

MYRT. Cupheanthus

MYRT. Eugenia

MYRT. Mearnsia

MYRT. Metrosideros

MYRT. Piliocalyx

MYRT. Pleurocalyptus

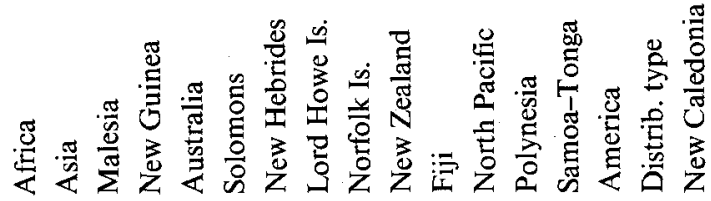

MYRT. Rhodomyrtus

$$
\text { (Archirhodomyrtus) }
$$

MYRT. Syzygium (Caryophyllus,

$$
\text { Jambosa) }
$$

MYRT. Tristaniopsis

MYRT. Xanthostemon

NEPE. Nepenthes

NYCT. Pisonia (Calpidia)

OLEA. Jasminum

OLEA. Linociera

OLEA. Olea

* OLEA. Osmanthus (Sect. Nothosmanthus)

ONCO. Oncotheca

ORCH. Acanthephippium

ORCH. Acianthus

ORCH. Agrostophyllum

ORCH. Anoectochilus

ORCH. Appendicula

ORCH. Bulbophyllum

ORCH. Calanthe

ORCH. Ceratostylis

ORCH. Chamaeanthus

ORCH. Cheirostylis

ORCH. Chrysoglossum

ORCH. Cleisostoma

ORCH. Clematepistephium

ORCH. Coelogyne

ORCH. Coilochilus

ORCH. Corybas

ORCH. Cryptostylis

ORCH. Dendrobium

ORCH. Didymoplexis

ORCH. Diplocaulobium

ORCH. Drymoanthus

ORCH. Earina

ORCH. Ephemerantha

ORCH. Epipogium

ORCH. Eria

ORCH. Erythrodes

ORCH. Eulophia

ORCH. Glomera

ORCH. Gonatostylis

ORCH. Goodyera

ORCH. Habenaria

ORCH. Hetaeria

ORCH. Liparis

ORCH. Malaxis

ORCH. Megastylis

ORCH. Microtatorchis

ORCH. Moerenhoutia

ORCH. Nervilia

ORCH. Oberonia

ORCH. Octarrhena

ORCH. Pachyplectron

ORCH. Peristylus

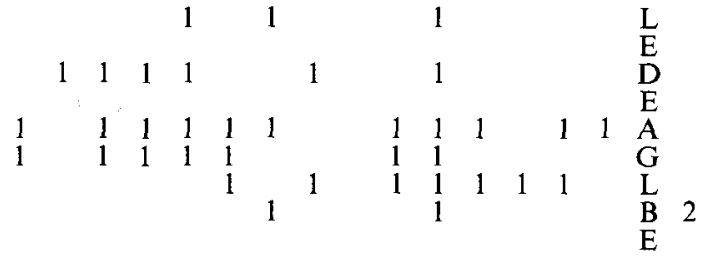

$\begin{array}{lllll}1 & 1 & 1 & 1 & 1\end{array}$

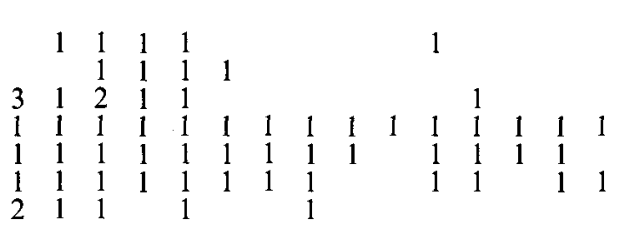

$\mathrm{C}$

(n)$$
\begin{array}{lllllll} 
& 1 & 1 & 1 & 1 & \\
& & & 1 & & \\
1 & 1 & 1 & 1 & 1 & 1
\end{array}
$$$$
\begin{array}{lllll}
1 & 1 & 1 & & 1 \\
1 & 1 & & 1 & 1
\end{array}
$$$$
\begin{array}{lllllll}
1 & 1 & 1 & 1 & 1 & 1 & 1 \\
& 1 & 2 & 1 & 1 & & 1 \\
& 1 & 1 & 1 & 1
\end{array}
$$$$
\begin{array}{lllllll}
1 & 1 & 1 & 1 & & 1 & 1
\end{array}
$$$$
\begin{array}{lllll}
1 & 2 & & 1 & 1
\end{array}
$$$$
\begin{array}{lllllll}
1 & 1 & 1 & 1 & 1 & 1 & 1 \\
1 & 1 & 1 & 1 & 1 & 1 & 1
\end{array}
$$$$
\begin{array}{lllllll}
1 & 1 & 1 & 1 & 1 & 1 & 1
\end{array}
$$$$
\begin{array}{lllllll}
1 & 1 & 1 & 1 & 1 & 1 & 1 \\
1 & 1 & 1 & 1 & 1 & 1 & 1
\end{array}
$$

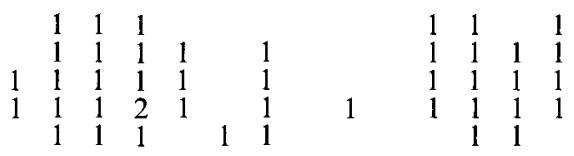$$
\begin{array}{llllll}
1 & 1 & & 1 & & \text { G } \\
1 & & 1 & 1 & & \text { L } \\
& 1 & 1 & 1 & & \text { F } \\
& & & & & \text { C } \\
1 & & 1 & 1 & & \text { D } \\
1 & & & 1 & 1 & \text { A } \\
1 & 1 & & & 1 & \text { A } \\
1 & 1 & & 1 & & \text { G } \\
& & & & & \text { E }
\end{array}
$$$$
\begin{array}{lllll}
\mathrm{E} & \mathrm{A} & \mathrm{A}
\end{array}
$$$$
\begin{array}{llllll}
1 & & 1 & 1 & 1 & \mathrm{~A} \\
1 & 1 & 1 & 1 & & \mathrm{C}
\end{array}
$$$$
\begin{array}{llllll}
1 & 1 & 1 & 1 & 1 & \text { A } \\
1 & 1 & 1 & 1 & 1 & A
\end{array}
$$ 
ORCH. Phajus

ORCH. Pholidota

ORCH. Phreatia

ORCH. Pristiglottis

ORCH. Pterostylis

ORCH. Rhynchophreatia

ORCH. Sarcochilus

ORCH. Schoenorchis

ORCH. Spathoglottis

ORCH. Spiranthes

ORCH. Taeniophyllum

ORCH. Thrixspermum

ORCH. Trachoma

ORCH. Tropidia

ORCH. Zeuxine

PALM. Actinokentia

PALM. Alloschmidia

PALM. Basselinia

PALM. Brongniartikentia

PALM. Burretiokentia

PALM. Campecarpus

PALM. Chambeyronia

PALM. Clinosperma

PALM. Cyphokentia

PALM. Cyphophoenix

PALM. Cyphosperma

PALM. Kentiopsis

PALM. Lavoixia

PALM. Mackeea

PALM. Moratia

PALM. Pritchardiopsis

PALM. Veillonia

PAND. Freycinetia

PAND. Pandanus

PAPI. Arthroclianthus

PAPI. Mucuna

PARA. Paracryphia

PASS. Passiflora

PHEL. Phelline

PHIL. Eustrephus

PHIL. Geitonoplesium

PIPE. Peperomia

PIPE. Piper

PITT. Pittosporum

PODO. Acmopyle

PODO. Dacrycarpus

PODO. Dacrydium

PODO. Decussocarpus

PODO. Falcatifolium

PODO. Parasitaxus

PODO Podocarpus

PODO. Prumnopitys

PROT. Beauprea

PROT. Eucarpha

PROT. Kermadecia

PROT. Sleumerodendron

PROT. Stenocarpus

PROT. Virotia

RHAM. Alphitonia

RHAM. Ventilago

RHIZ. Crossostylis

RUBI. Atractocarpus

RUBI. Coelospermum

RUBI. Cyclophyllum

RUBI. Gardenia

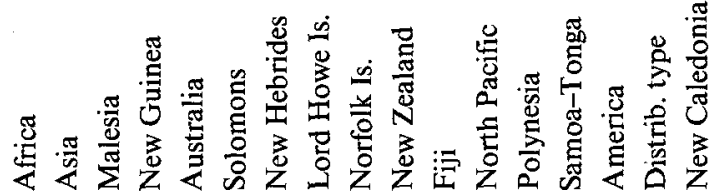

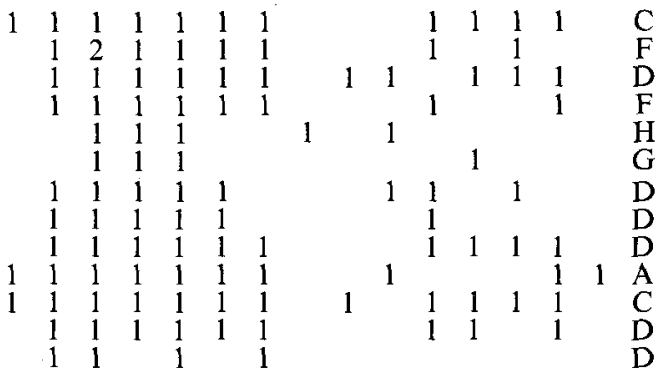

$\begin{array}{llllllllllllll} & 1 & 1 & 1 & & 1 & 1 & 1 & 1 & & 1 & 1 & \mathrm{~A} \\ 1 & 1 & 1 & 1 & 1 & 1 & 1 & & 1 & 1 & & 1 & & \mathrm{C}\end{array}$

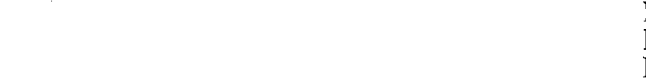

$\begin{array}{llllllllllllllll} & 1 & 1 & 1 & 1 & 1 & 1 & & 1 & 1 & 1 & 1 & 1 & 1 & & \mathrm{D} \\ 1 & 1 & 1 & 1 & 1 & 1 & 1 & 1 & & & 1 & 1 & 1 & 1 & & C \\ 1 & 1 & 1 & 1 & 1 & 1 & 1 & 1 & & & 1 & 1 & 1 & 1 & 1 & A\end{array}$

$\begin{array}{lllllllllllllll} & 1 & 1 & 1 & 1 & 1 & 1 & 1 & 1 & \mathrm{E}\end{array}$

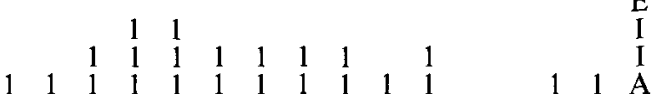

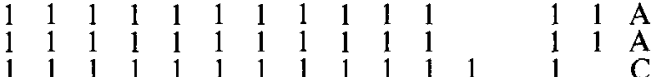

$\begin{array}{llllllll}1 & 1 & 1 & 1 & 1 & 1 & 1 & \mathrm{~L}\end{array}$

$\begin{array}{lllllllll}1 & 1 & 1 & 1 & 1 & 1 & 1 & 1 & J \\ & 1 & 1 & 1 & & & 1 & 1 & J\end{array}$

$\begin{array}{llllllllll}1 & 1 & 1 & 1 & 1 & 1 & 1 & 1 & 1 & \mathrm{E} \\ & 1 & 1 & 1 & & 1 & & & 1 & \mathrm{~J}\end{array}$

111

$\begin{array}{lllllll}1 & 1 & 1 & 1 & 1 & 1 & 1 \\ & 1 & 1 & 1 & 1 & & 1 \\ & & & & & 1 & 1\end{array}$

$\begin{array}{llllll}1 & 1 & 1 & 1 & & \text { D } \\ 1 & 1 & & & 1 & \text { A } \\ 1 & & 1 & 1 & & \text { L }\end{array}$

$\begin{array}{llll}1 & 1 & 1 & 1\end{array}$

$\begin{array}{lllllll}1 & 1 & 1 & 1 & 1 & 1 & 1\end{array}$

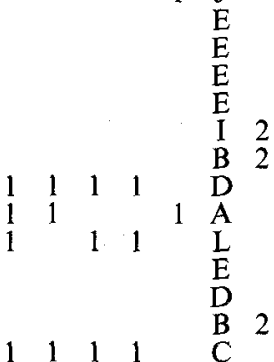


RUBI. Guettarda

RUBI. Ixora

RUBI. Morierina

RUBI. Morinda

RUBI. Mussaenda

RUBI. Psychotria

RUBI. Randia

RUBI. Rhopalobrachium

RUBI. Tarenna

RUTA. Dutaillyea

RUTA Geijera

RUTA. Medicosma

RUTA. Melicope

RUTA. Micromelum

RUTA. Sarcomelicope

RUTA. Zanthoxylum

RUTA. Zieridium

SANT. Amphorogyne

SANT. Daenikera

SANT. Exocarpos

* SANT. Santalum (Sect. Santalum)

SAPI. Alectryon

SAPI. Arytera

SAPI. Cupaniopsis

SAPI. Elattostachys

SAPI. Gongrodiscus

SAPI. Guioa

SAPI. Harpullia

SAPI. Podonephelium

SAPI. Storthocalyx

SAPO. Beccariella

SAPO. Bureavella

SAPO. Leptostylis

SAPO. Manilkara

SAPO. Mimusops

SAPO. Niemeyera

SAPO. Ochrothallus

SAPO. Pichonia

SAPO. Planchonella

SAPO. Pycnandra

SAPO. Pyriluma

SAPO. Sebertia

SAXI. Polyosma

SAXI. Quintinia

SIMA. Soulamea

SMIL. Smilax

SOLA. Duboisia

SPHE. Sphenostemon

STER. Sterculia

STRA. Strasburgeria

SYMP. Symplocos

TAXA. Austrotaxus

THYM. Lethedon

THYM. Wickstroemia

TILI. Trichospermum

TRIM. Trimenia

TRIU. Sciaphila

ULMA. Celtis

UTRI. Dendrocnide

URTI. Procris

VERB. Gmelina

VERB. Oxera

VERB. Vitex

VIOL. Agatea

VIOL. Hybanthus

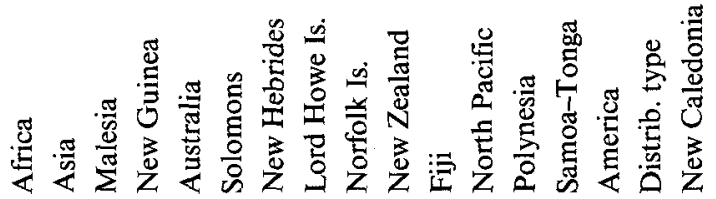

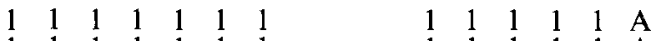

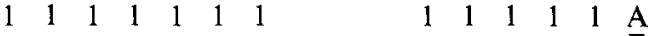

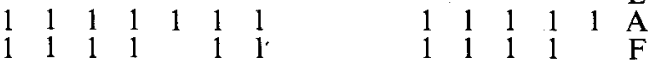

$\begin{array}{lllllllllllllll}2 & 1 & 1 & 1 & 1 & 1 & 1 & 1 & & 1 & 1 & 1 & 1 & 1 & A\end{array}$

$\begin{array}{llllllllllllllll}2 & 1 & 1 & 1 & 1 & 1 & 1 & 1 & & 1 & 1 & & 1 & 1 & \mathrm{~A}\end{array}$

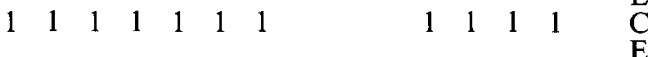

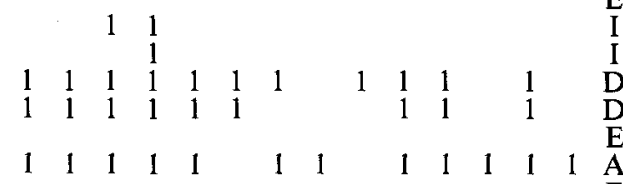

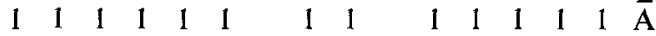

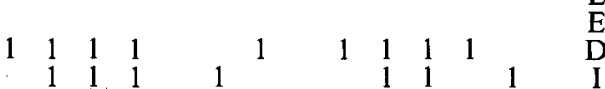

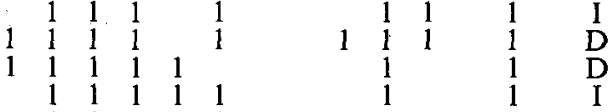

$\begin{array}{lllll}1 & 1 & 1 & 1 & 1\end{array}$

$\begin{array}{lllllll}1 & 1 & 1 & 1 & 1 & & 1 \\ 1 & 1 & 1 & 1 & 1 & 1\end{array}$

$\begin{array}{lll}1 & 1 & 1\end{array}$

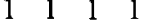

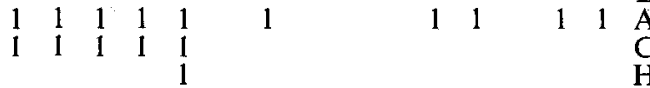

$\begin{array}{llll}1 & 1 & \mathrm{E}\end{array}$

$\begin{array}{lllllllllllll}1 & 1 & 1 & 1 & 1 & 1 & 1 & 1 & 1 & 1 & 1 & 1 & 1\end{array}$

E
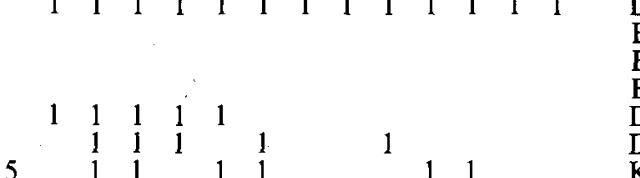

$\begin{array}{llllllllllllllll}5 & & 1 & 1 & & 1 & 1 & & & 1 & 1 & & & & \mathbf{K} & 2\end{array}$

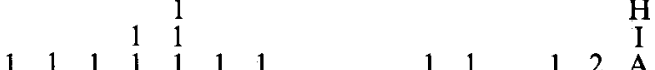

1210

$\begin{array}{lllllllllllll}1 & 1 & 1 & 1 & 1 & 1 & 1 & & 1 & 1 & & 1 & A\end{array}$

$\begin{array}{llll}1 & 1 & \mathrm{E} & \\ \mathrm{B} & 2 & \end{array}$

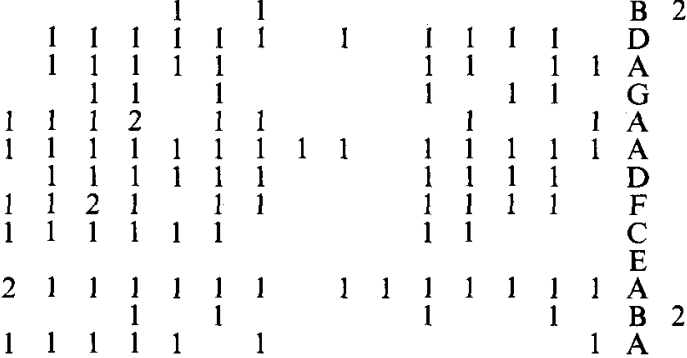


WINT, Belliolum

$\begin{array}{ll}\text { WINT. } & \text { Bubbia } \\ \text { WINT. } & \text { Exospermum }\end{array}$

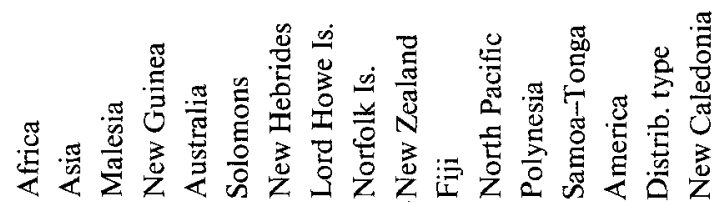

WINT. Zygogynum

$\begin{array}{llll}1 & 1 & 1\end{array}$

I
I
E

Note added in proof. A version of this paper with updated figures and other modifications was published in the symposium volume 'Biogeography of the Tropical Pacific' (F. J. Radovsky et al., eds.; Bishop Museum Special Publication no. 72 (1984)). 